\title{
Lista actualizada de la diversidad de los mamíferos del Perú y una propuesta para su actualización
}

\author{
Updated list of the diversity of mammals from Peru and a proposal for its updating \\ Víctor Pacheco* 1,2 \\ https://orcid.org/0000-0002-1005-135X \\ vpachecot@unmsm.edu.pe \\ Silvia Diaz ${ }^{1}$ \\ https://orcid.org/0000-0002-9344-4991 \\ silvia.diaz2@unmsm.edu.pe \\ Laura Graham-Angeles ${ }^{1}$ \\ https://orcid.org/0000-0003-1966-6534 \\ laura.graham@unmsm.edu.pe \\ Marisel Flores-Quispe ${ }^{3,4}$ \\ https://orcid.org/0000-0002-6543-2360 \\ fq.marisel@gmail.com

\section{Resumen} \\ La lista de mamíferos del Perú más reciente, publicada en el año 2020, compiló un \\ total de 569 especies y 82 especies endémicas, sin embargo, en corto tiempo varios \\ cambios taxonómicos han ocurrido y obligan a presentar otra lista actualizada de \\ todas las especies de mamíferos con registros en el Perú. Esta nueva lista actuali- \\ zada hasta noviembre de 2021 incluye 573 especies, 223 géneros, 51 familias y 13 \\ órdenes: Didelphimorphia (47), Paucituberculata (2), Sirenia (1), Cingulata (5), Pilosa \\ (7), Primates (42), Lagomorpha (2), Eulipotyphla (3), Carnivora (33), Perissodactyla \\ (2), Artiodactyla (46, incluyendo 32 cetáceos), Rodentia (194) y Chiroptera (189); \\ de las cuales, 87 especies son endémicas para el país. Por otro lado, la necesidad \\ de contar con listas taxonómicas válidas y actualizadas para el uso en toma de \\ decisiones, nos lleva a proponer como una estrategia óptima que la Asociación de \\ Mastozoólogos del Perú (AMP) asuma el rol de mantener actualizada una lista que \\ cubra las necesidades de los diferentes usuarios, tal como organizaciones similares \\ lo vienen haciendo en países vecinos con el apoyo del Estado y ONGs.
}
Giüseppy Calizaya-Mamani ${ }^{3,4}$
https://orcid.org/0000-0002-9710-3107 epiorama@gmail.com
Dennisse Ruelas ${ }^{1,2}$
https://orcid.org/0000-0002-3793-8639
druelasp@unmsm.edu.pe
Pamela Sánchez-Vendizú 5
https://orcid.org/0000-0002-3374-6031
p.sanchez.vendizu@gmail.com

\section{*Corresponding author}

1 Universidad Nacional Mayor de San Marcos, Museo de Historia Natural, Apartado 14-0434, Lima-15072, Perú.

2 Universidad Nacional Mayor de San Marcos, Facultad de Ciencias Biológicas, Instituto de Ciencias Biológicas "Antonio Raimondi", Lima, Perú.

3 Programa de Conservación de Murciélagos de Perú (PCMP), Perú.

4 Consultoría \& Monitoreo Perú S.A.C. Servicio de Implementación de Planes de Manejo Biológico y Compromiso de Biodiversidad-Anglo American Quellaveco S.A., Arequipa, Perú.

5 Programa de Pós-Graduação em Zoologia, Universidade Federal do Pará, Museo Paraense Emilio Goeldi, Pará, Brasil.

\section{Citación}

Pacheco V, Diaz S, Graham-Angeles L, Flores-Quispe M, Calizaya-Mamani G, Ruelas D, SánchezVendizú P. 2021. Lista actualizada de la diversidad de los mamíferos del Perú y una propuesta para su actualización. Revista peruana de biología 28(4): e21019 001030 (Noviembre 2021). doi: http://dx.doi. org/10.15381/rpb.v28i4.21019

\section{Abstract}

The most recent list of mammals in Peru, published in 2020, compiled a total of 569 species, including 82 endemic species. However, several taxonomic changes have occurred in this short time, and it makes necessary to publish an updated list of all mammalian species recorded in Peru. This new list is updated until November 2021 and includes 573 species, 223 genera, 51 families and 13 orders: Didelphimorphia (47), Paucituberculata (2), Sirenia (1), Cingulata (5), Pilosa (7), Primates (42), Lagomorpha (2), Eulipotyphla (3), Carnivora (33), Perissodactyla (2), Artiodactyla (46, including 32 cetaceans), Rodentia (194) and Chiroptera (189); of which 87 species are endemic to the country. On the other hand, the need to have an optimal strategy that the Asociación de Mastozoólogos del Perú (AMP) assume the role to produce and maintain an updated list to satisfy the needs of different users, as similar organizations are doing in neighboring countries with the support of the State and NGOs.

\section{Palabras clave:}

Mastofauna peruana; mamíferos; lista anotada; taxonomía; endemismo; conservación; Perú; biodiversidad.

\section{Keywords:}

Peruvian mammals; Mammals; checklist; taxonomy; endemism; conservation; Peru; biodiversity. valid and updated taxonomic lists for use in decision-making, leads us to propose as $\begin{array}{ll}\text { Presentado: } & 13 / 08 / 2021 \\ \text { Aceptado: } & 03 / 11 / 2021 \\ \text { Publicado online: } & \text { 26/11/2021 }\end{array}$

Editor: Leonardo Romero 


\section{Introducción}

Recientemente, Pacheco et al. (2020a) publicaron la primera lista completa en una serie de tres artículos, donde se compiló la riqueza de mamíferos en 569 especies y 82 endémicos y se proveyó comentarios a 191 especies (incluyendo 22 especies endémicas) de once órdenes taxonómicos: Didelphimorphia, Paucituberculata, Sirenia, Cingulata, Pilosa, Primates, Lagomorpha, Eulipotyphla, Carnivora, Perissodactyla y Artiodactyla. Sin embargo, varios cambios taxonómicos en mamíferos han sido reportados en este corto tiempo que afectan tanto el número como el contenido de especies y que hacen necesaria una actualización. La lista de riqueza de especies más completa con 508 especies (Pacheco et al. 2009) fue actualizada recientemente con un total de 569 especies (Medina et al. 2016b, Pacheco et al. 2020a) (Fig. 1), mostrando un incremento constante de la diversidad de especies con respecto a las listas anteriores de Tovar (1971) con 378 especies, McNeely et al. (1990) con 361 especies, Pacheco et al. (1995) con 460 especies y Pacheco et al. (2009) con 508 especies (Fig. 1); concordando además con Serrano-Villavicencio et al. (2020) que el primer listado de mamíferos para el Perú fue producido por Tschudi (1844) con 119 especies.

Los cambios en esta nueva lista respecto a la anterior (Pacheco et al. 2020a) han ocurrido principalmente por el incremento de especies nuevas como el marsupial Marmosa (Micoureus) jansae (Voss et al. 2021), los murciélagos Cynomops kuizha (Arenas-Viveros et al. 2021) e Histiotus mochica (Velazco et al. 2021b) y los roedores Oligoryzomys guille (Hurtado 2021), Oxymycterus willkaurco (Zeballos et al. 2021), Thomasomys antoniobracki (Ruelas \& Pacheco 2021), Nephelomys ricardopalmai (Ruelas et al. 2021) y Neacomys aletheia (Semedo et al. 2021); así como por los primeros reportes para el Perú de Eumops bonariensis (Ruelas \& Soria 2021), Platyrrhinus fusciventris (Velazco et al. 2021a); la elevación a especie válida de Neacomys carceleni (Brito et al. 2021) y Glossophaga bakeri (Velazco et al. 2021); el registro de Pteronotus fuscus en lugar de P. parnelli (Ruelas \& Soria 2021), Diclidurus isabella en lugar de D. scutatus (Velazco et al. 2021a), Lichonycteris obscura en lugar de L. degener (Zamora-Gutierrez \& Ortega 2020) y Holochilus nanus en lugar de H. sciureus (Prado et al. 2021); y el retiro de Sturnira luisi (Velazco \& Patterson 2013) y de Tamandua mexicana (Ruiz García et al. 2021) de la lista, entre otros cambios. Además, cambios nomenclaturales importantes incluyen la propuesta de Dicotyles en reemplazo de Pecari (Acosta et al. 2020) y Neogale por Mustela (Patterson et al. 2021).

Sin duda, una lista de especies actualizada, precisa y detallada es una herramienta utilizada en diversos ámbitos, como el académico, científico, educativo, y de gestión. En este último, las listas taxonómicas, con información adicional, son imprescindibles para la toma de decisiones sobre medio ambiente, salud, uso y conservación de recursos, a diferentes niveles de gobierno (e.g. Gobierno central, Gobiernos regionales, Gobiernos municipales). Por ejemplo, hay especies que son indicadoras de cali- dad ambiental (Michel-Vargas et al. 2019), endémicas y amenazadas que deben ser evaluadas en proyectos ambientales (Patiño-Guío 2014); otras especies están implicadas como reservorios de enfermedades (Arrivillaga \& Caraballo 2020, Vargas-Linares et al. 2014) que necesitan contar con un plan adecuado para su gestión y vigilancia (Elías et al. 2020); y otras están listadas en acuerdos internacionales como Convención sobre el Comercio Internacional de Especies Amenazadas de Fauna y Flora Silvestres (CITES). Debido a las condiciones propias de la ciencia y exploración que resultan en un incremento en la cantidad de cambios taxonómicos producto de revisiones sistemáticas, ampliaciones de rango de distribuciones o por el reporte de especies nuevas, actualizar una lista por periodos de 5 o 10 años no satisface las necesidades de los diferentes usuarios. Esto explica por qué países vecinos hacen esfuerzos similares y constantes para documentar su biodiversidad de mamíferos como Colombia (Ramírez-Chaves et al. 2021), Ecuador (Tirira et al. 2020), Brasil (Quintela et al. 2020), Bolivia (Aguirre et al. 2019), Chile (D'Elía et al. 2020) y Argentina (Teta et al. 2018). Dada la complejidad y el esfuerzo de mantener actualizada estas listas, cada vez son más los países que encargan este objetivo a asociaciones profesionales, como el caso de Ecuador (Tirira et al. 2020) y Colombia (Ramírez-Chaves et al. 2021), pero esta alternativa no se ha sugerido aún en el Perú; quedando esta responsabilidad a la iniciativa y recursos de algunos investigadores (e.g. Medina et al. 2016b, Pacheco et al. 2020a, Velazco 2021).

En este trabajo presentamos una lista actualizada de todas las especies de mamíferos vivientes reportados para el Perú hasta noviembre del 2021, con la finalidad de que sea un punto de partida para investigadores y usuarios de entidades gubernamentales y no gubernamentales.

\section{Material y métodos}

En este trabajo se incluyen todos los mamíferos con registro de presencia en el Perú, tomando como punto de partida las listas de Pacheco et al. (2009, 2018b, 2020a), manteniéndose la distribución por ecorregiones según Brack-Egg (1986). Se incluyen nombres comunes en español, para nombres comunes en inglés se puede recurrir a Pacheco et al. (2009) u otras fuentes (e.g. Gardner 2008; Wilson \& Mittermeier 2009, 2011; Mittermeier et al. 2013; Patton et al. 2015; Wilson et al. 2016, 2017). Esta lista no incluye taxones potencialmente presentes en el país. Para una lista de mamíferos exóticos incluyendo especies domesticadas véase Pacheco et al. (2009) y Cossíos (2010). El ordenamiento taxonómico desde orden hasta familia es filogenético siguiendo el ordenamiento de Pacheco et al. $(2009,2020$ a) y trabajos recientes; continuando con los géneros y especies ordenados alfabéticamente. La presencia de cada especie está sustentada por al menos una referencia bibliográfica. Además, se consideran como especies endémicas (E) aquellas que tienen registros exclusivamente en territorio peruano. 
El presente listado incluye a las especies vivientes y las consideradas potencialmente extintas (e.g. Cuscomys oblativus, Lagostomus crassus, Melanomys zunigae); o potencialmente extintas en Perú como Chinchilla chinchilla.

\section{Resultados}

La diversidad de los mamíferos terrestres, acuáticos y marinos registrados para Perú alcanza a 13 órdenes, 51 familias, 223 géneros y 573 especies (Tabla 1). Los mamíferos incluyen 47 didelfimorfos, 2 paucituberculados, 1 sirenio, 5 cingulados, 7 pilosos, 42 primates, 194 roedores, 2 lagomorfos, 3 eulipotiflanos, 189 quirópteros, 33 carnívoros, 2 perisodáctilos y 46 artiodáctilos (incluyendo 32 cetáceos) (Tabla 1, Apéndice 1). Estos resultados, indican que Perú es el país con mayor riqueza de especies de mamíferos en el Neotrópico después de Brasil (Tabla 2). Casi las dos terceras partes de esta diversidad (383 especies, 66.8\%) están compuestas por pequeños mamíferos como roedores y murciélagos. A nivel de ecorregiones, se encuentra que la Selva baja, con 320 especies (55.8\%), es la ecorregión con la más alta riqueza de especies, seguida por las Yungas con 256 especies (44.7\%); siendo el Páramo (26 especies, $4.5 \%$ ) la ecorregión con menor riqueza (Tabla 3 ).

Con respecto al endemismo, Perú tiene 87 especies endémicas, lo que lo ubica en tercer lugar en el Neotrópico después de Brasil y México (Tabla 2). Tres géneros de mamíferos (Eremoryzomys, Cuscomys y Tomopeas) son endémicos para Perú. El murciélago Tomopeas es endémico del flanco occidental de los Andes; el roedor Cuscomys de las Yungas del sur y Eremoryzomys del valle del
Marañón. A nivel de especies, 87 (15.2\%) son endémicas de Perú, que incluyen a 1 cingulado, 10 didelfimorfos, 9 murciélagos, 9 primates, 56 roedores y 2 eulipotiflanos (Tabla 1, Apéndice 1); siendo los roedores el grupo con mayor porcentaje de endémicos (64.4\%). Por el contrario, las Yungas albergan la mayor cantidad de especies endémicas (48 especies, 55.2\%) seguida por Selva baja (18 especies, $20.7 \%$ ) (Tabla 3 ).

Tabla 1. Diversidad y endemismo de los mamíferos del Perú por categorías taxonómicas

\begin{tabular}{|c|c|c|c|c|c|c|c|}
\hline Órdenes & 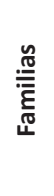 & 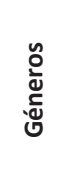 & 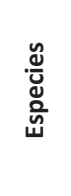 & 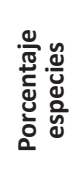 & 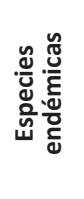 & 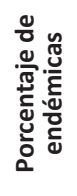 & 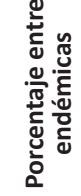 \\
\hline Didelphimorphia & 1 & 15 & 47 & 8.2 & 10 & 1.7 & 11.5 \\
\hline Paucituberculata & 1 & 2 & 2 & 0.3 & 0 & 0.0 & 0.0 \\
\hline Sirenia & 1 & 1 & 1 & 0.2 & 0 & 0.0 & 0.0 \\
\hline Cingulata & 2 & 3 & 5 & 0.9 & 1 & 0.2 & 1.1 \\
\hline Pilosa & 4 & 5 & 7 & 1.2 & 0 & 0.0 & 0.0 \\
\hline Primates & 3 & 12 & 42 & 7.3 & 9 & 1.6 & 10.3 \\
\hline Rodentia & 11 & 67 & 194 & 33.9 & 56 & 9.8 & 64.4 \\
\hline Lagomorpha & 1 & 1 & 2 & 0.3 & 0 & 0.0 & 0.0 \\
\hline Eulipotyphla & 1 & 1 & 3 & 0.5 & 2 & 0.3 & 2.3 \\
\hline Chiroptera & 8 & 64 & 189 & 33.0 & 9 & 1.6 & 10.3 \\
\hline Carnivora & 7 & 20 & 33 & 5.8 & 0 & 0.0 & 0.0 \\
\hline Perissodactyla & 1 & 1 & 2 & 0.3 & 0 & 0.0 & 0.0 \\
\hline Artiodactyla & 10 & 31 & 46 & 8.0 & 0 & 0.0 & 0.0 \\
\hline Total & 51 & 223 & 573 & 100.0 & 87 & 15.2 & 100.0 \\
\hline
\end{tabular}

Tabla 2. Diversidad de mamíferos de Perú comparado con la Región Neotropical y el Mundo. Para esta comparación el orden Artiodactyla incluye a los antiguos órdenes Cetacea y Artiodactyla (Asher \& Helgen 2010).

\begin{tabular}{|c|c|c|c|c|c|c|c|}
\hline País & 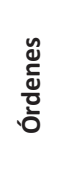 & 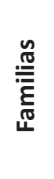 & 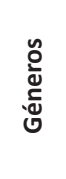 & 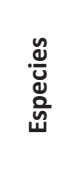 & 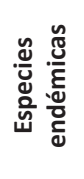 & 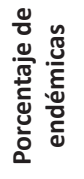 & Fuente \\
\hline Indonesia & - & - & - & 773 & 408 & 52.8 & Maryanto et al. 2019 \\
\hline Brasil & 11 & 51 & 249 & 751 & 223 & 29.7 & Quintela et al. 2020 \\
\hline Perú & 13 & 51 & 223 & 573 & 87 & 15.2 & Este trabajo \\
\hline México & 13 & 46 & 200 & 564 & 162 & 28.7 & Sánchez-Cordero et al. 2014 \\
\hline Colombia & 13 & 50 & 214 & 543 & 62 & 11.4 & Ramírez-Chaves et al. 2021 \\
\hline Ecuador & 13 & 52 & 208 & 448 & 50 & 11.2 & Tirira et al. 2020 \\
\hline Argentina & 12 & 46 & 181 & 409 & - & - & Teta et al. 2018 \\
\hline Bolivia & 11 & 46 & 196 & 406 & 25 & 6.2 & Aguirre et al. 2019 \\
\hline Venezuela & 13 & 47 & 184 & 390 & 30 & 7.7 & Sánchez \& Lew 2012 \\
\hline Costa Rica & 12 & 44 & 142 & 249 & 23 & 9.2 & Rodríguez-Herrera et al. 2014 \\
\hline Guyana & 12 & 35 & 134 & 233 & 2 & 0.9 & Lim \& Catzeflis 2014, Ruedas 2017 \\
\hline Paraguay & 10 & 34 & 116 & 181 & - & - & de la Sancha et al. 2017 \\
\hline Chile & 8 & 31 & 85 & 163 & 20 & 12.3 & D’Elía et al. 2020 \\
\hline Uruguay & 7 & 29 & 83 & 117 & 1 & 0.9 & González \& Lessa 2014 \\
\hline Mundo & & & & 6399 & & & Burgin et al. 2018 \\
\hline
\end{tabular}


Tabla 3. Diversidad de especies de mamíferos del Perú por ecorregiones (según Brack-Egg, 1986).

\begin{tabular}{|c|c|c|c|c|}
\hline Ecorregión & 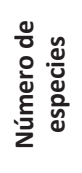 & 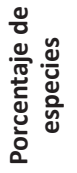 & 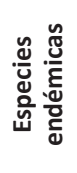 & 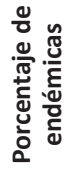 \\
\hline Oceánica & 30 & 5.2 & 0 & 0.0 \\
\hline Bosque Pluvial Pacífico & 69 & 12.0 & 0 & 0.0 \\
\hline Bosque Seco Ecuatorial & 81 & 14.1 & 4 & 4.6 \\
\hline Costa & 66 & 11.5 & 16 & 18.4 \\
\hline Vertiente Occidental & 71 & 12.4 & 15 & 17.2 \\
\hline Páramo & 26 & 4.5 & 4 & 4.6 \\
\hline Puna & 71 & 12.4 & 14 & 16.1 \\
\hline Yungas & 256 & 44.7 & 48 & 55.2 \\
\hline Selva Baja & 320 & 55.8 & 18 & 20.7 \\
\hline Sabana de Palmeras & 78 & 13.6 & 0 & 0.0 \\
\hline
\end{tabular}

\section{Discusión}

La diversidad de mamíferos del Perú estimada hasta noviembre 2021 es de 573 especies y está constituida por los siguientes órdenes: Didelphimorphia (47), Paucituberculata (2), Sirenia (1), Pilosa (7), Cingulata (5), Primates (42), Rodentia (194), Lagomorpha (2), Eulipotyphla (3), Chiroptera (189), Carnivora (33), Perissodactyla (2) y Artiodactyla (46). Este estimado ubica a Perú como el segundo país más diverso en Sudamérica, en el Neotrópico y las Américas (Tabla 2). Además, junto con Indonesia, Brasil, México y Colombia, Perú es uno de los cinco países más diversos del mundo (Tabla 2). Perú cuenta también con 87 especies endémicas, lo que la ubica en tercer lugar en el Neotrópico después de Brasil y México (Tabla 2), estimado similar al de otros países andinos como Ecuador, Colombia y Chile.

No obstante tener altos estimados de riqueza de especies, se puede decir con certeza que la diversidad de Perú es todavía poco conocida. La disparidad del conocimiento de los mamíferos se manifiesta en que aún son muy pocas las regiones que cuentan con un listado de especies como Ucayali (Quintana et al. 2009), Arequipa (Medina et al. 2021) y Loreto (en prensa) o listado parcial (marsupiales, roedores y murciélagos) como San Martín (Ruelas \& Pacheco 2021); pero, exceptuando Arequipa y Loreto, las listas de las otras regiones necesitan ser actualizadas. Pacheco et al. (2020a) hicieron el primer intento de producir una lista actualizada para diez órdenes de mamíferos y para todos los departamentos, quedando pendiente las listas anotadas de Chiroptera y Rodentia. La continuación en la exploración científica del país desde el último listado de Pacheco et al. (2009) demuestra además que muchas regiones tienen aún grandes vacíos de información, que no han sido evaluados por factores que incluyen inaccesibilidad y falta de recursos suficientes para acceder a ellos. Contradictoriamente, las principales Áreas Naturales Protegidas, por ejemplo: Parques Nacionales (PN), Reservas Nacionales (RN) y Santuarios
Nacionales (SN), no tienen en general un listado actualizado de la diversidad de mamíferos que protegen o presentan listas sesgadas a los mamíferos grandes o a algún orden específico. Por ejemplo, la última lista del PN del Manu (Solari et al. 2006) requiere ser actualizada; las listas de RN Pacaya Samiria (Aquino \& Calle 2003) y del SN Tabaconas Namballe (Mena \& Pacheco 2020) fueron de mamíferos de caza y de mamíferos grandes; y la lista de Mena et al. (2020) trataron sobre la diversidad de murciélagos en el norte peruano. Sumado a eso, la investigación dentro de áreas protegidas tanto para colecta de ejemplares como el acceso a recursos genéticos es sumamente limitado (por no decir impedido) debido a procesos administrativos largos, regulaciones difíciles de cumplir y criterios subjetivos para la toma de decisiones, que impiden el avance de estudios sistemáticos, evolutivos y biogeográficos (Aguilar et al. 2010, von May et al. 2012) aunque confiamos esta percepción cambie con la nueva normativa de acceso a recursos genéticos (DS № 019-2021-MINAM) y la de promoción a la investigación en Áreas Naturales Protegidas (RP N ${ }^{\circ}$ 106-2020-SERNANP). Dada esta escasez de información primaria basada en ejemplares de colecciones científicas y observaciones documentadas, aunada a la dinámica de la ciencia reflejada en los cambios taxonómicos resultado de revisiones sistemáticas de géneros y especies, ampliaciones de distribución y mayores esfuerzos en el muestreo de localidades no evaluadas previamente, anticipamos que los componentes de esta lista se van a incrementar rápidamente en los siguientes años.

El rápido avance del conocimiento de la diversidad de mamíferos en los últimos años (Fig. 1) y su importancia en la toma de decisiones y políticas públicas hace necesaria una nueva estrategia para mantener actualizadas estas listas. Los cambios taxonómicos son tan numerosos y técnicamente complejos que mantener una lista actualizada requiere la participación de cada vez más expertos en el grupo taxonómico y por ende el soporte administrativo, de infraestructura, técnico y económico necesario para ello. De igual forma, las bases de datos en las que se almacena esta información requieren de constante y cuidadosa actualización. Así, algunos países vecinos recurren a sus expertos locales, con participación de expertos extranjeros, a través de las asociaciones de mastozoólogos locales como el caso de la Asociación Ecuatoriana de Mastozoología (Tirira et al. 2020) y la Sociedad Colombiana de Mastozoología (Ramírez-Chaves et al. 2021). Por ello, consideramos que la Asociación de Mastozoólogos del Perú puede cumplir eficazmente este rol formando comisiones por especialidad y alianzas con entidades gubernamentales como Servicio Nacional Forestal y de Fauna Silvestre (SERFOR), Servicio Nacional de Áreas Naturales Protegidas (SERNANP) y museos de historia natural nacionales con el objetivo de tener listas actualizadas en forma regular.

Por otro lado, el caso de los mamíferos es un ejemplo de la magnitud de los cambios taxonómicos que ocurren también en otros grupos de flora y fauna. Teniendo en cuenta que estas listas de especies son utilizadas por los organismos del gobierno como el SERFOR, SERNANP, 
Ministerio de Educación (MINEDU), Ministerio de Cultura (CULTURA), Ministerio de Energía y Minas (MINEM), Organismo de Evaluación y Fiscalización Ambiental (OEFA), entre otros; es necesario una alianza entre estos órganos de gobierno y la Academia, con el fin de que la Academia cuente con el apoyo gubernamental necesario para el mantenimiento de estos listados, los cuales deberían incluir por lo menos a los grupos taxonómicos de flora y fauna presentes en las listas de la Convención sobre el Comercio Internacional de Especies Amenazadas de Fauna y Flora Silvestres (CITES), listas de especies amenazadas según el Decreto Supremo Nº04-2014-MINAGRI, y otras similares. Es necesario sincerar que, si los organismos a nivel nacional y regional son grandes usuarios de estas listas, se debería procurar tener los mecanismos económicos necesarios para que este esfuerzo de mantener listas actualizadas de la diversidad de especies de nuestro país se mantenga constante. Algunos ejemplos de esta sinergia son las listas de peces continentales (Ortega et al. 2011) y anfibios y reptiles (MINAM 2018). Continuar estos esfuerzos interinstitucionales de forma sostenida ayudaría a conocer mejor la real diversidad del

Perú.

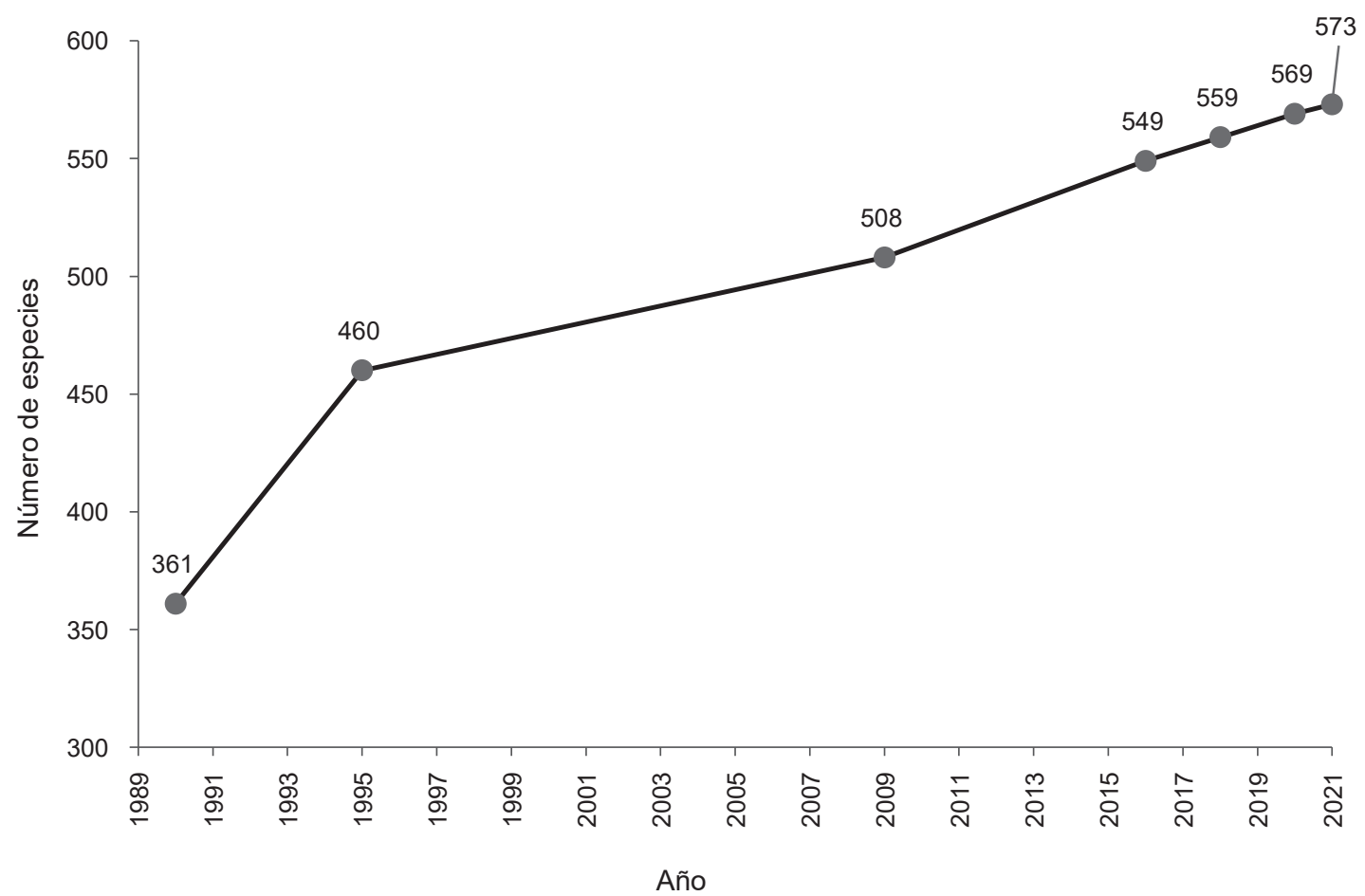

Figura 1. Riqueza de especies de mamíferos del Perú en orden cronológico desde fines del siglo XX.

\section{Literatura citada}

Abba AM, Superina M. 2010. The 2009/2010 Armadillo Red List Assessment. Edentata 11(2): 135-184. https:// doi.org/10.5537/020.011.0203

Abreu-Jr EF, Pavan S, Tsuchiya MTN, et al. 2020. Museomics of tree squirrels: a dense taxon sampling of mitogenomes reveals hidden diversity, phenotypic convergence, and the need of a taxonomic overhaul. BMC Evolutionary Biology 20(77): 1-25. https://doi.org/10.1186/ s12862-020-01639-y

Acosta LE, Garbino GST, Gasparini GM, Parisi-Dutra R. 2020. Unraveling the nomenclatural puzzle of the collared and white-lipped peccaries (Mammalia, Cetartiodactyla, Tayassuidae). Zootaxa 4851(1): 060-080. https://doi. org/10.11646/zootaxa.4851.1.2

Aguilar C, Ramírez C, Rivera D, et al. 2010. Anfibios andinos del Perú fuera de Áreas Naturales Protegidas: amenazas y estado de conservación. Revista Peruana de Biología 17(1): 5-28. https://doi.org/10.15381/rpb.v17i1.46

Aguirre LF, Tarifa T, Wallace RB, et al. 2019. Lista actualizada y comentada de los mamíferos de Bolivia. Ecología en Bolivia 54(2): 107-147.
Allgas N, Shanee S, Alarcón A, et al. 2015. Nuevos registros de Xenarthra para el nororiente de Perú, con notas sobre su distribución y conservación. Edentata 16: 28-36.

Amanzo J. 2003. Evaluación de la diversidad biológica de mamíferos del Santuario Nacional Tabaconas Namballe. Pp. 94-113. En: J Amanzo, ed. Evaluación biológica rápida del Santuario Nacional Tabaconas Namballe y zonas aledañas. Informe WWF-OPP QM-91, Perú. 212 pp. <https://d144yw6o2d13bk.cloudfront.net/downloads/informe_final_sntn.pdf $>$. Acceso 15/02/2019.

Angulo SR, Diaz MM. 2004. Nuevos registros de Sphaeronycteris toxophyllum para la cuenca Amazónica de Perú. Mastozoología Neotropical 11: 233-236.

Aquino R, Arévalo I, Pezo E, López L. 2021. Estado actual de Cheracebus sp. (Primates: Pitheciidae) y de su hábitat entre los ríos Tigre y Nanay, Amazonía peruana. Revista Peruana de Biología 28(2): e20463. https://doi. org/10.15381/rpb.v28i2.20463

Aquino R, Calle A. 2003. Evaluación del estado de conservación de los mamíferos de caza: un modelo comparativo en comunidades de la Reserva Nacional Pacaya Samiria (Loreto, Perú). Revista Peruana de Biología 10(2): 163-174. https://doi.org/10.15381/rpb.v10i2.2498 
Aquino R, Charpentier E, García G, et al. 2016. First record of Lagothrix flavicauda on the eastern side of the río Huallaga: An expansion of its known geographic distribution. Primate Conservation (30): 15-20.

Aquino R, Lopez L, Falcón R, et al. 2019. First inventory of primates in the montane forests of the Pasco and Ucayali Regions, Peruvian Amazon. Primate Conservation (33): 1-11.

Aquino R, Lopez L, Gálvez H, et al. 2018. Current status of Ateles belzebuth in montane forests of the Peruvian Amazon. Primate Conservation 32: 19-39.

Aquino R, Terrones W, Cornejo F, Heymann EW. 2008. Geographic distribution and possible taxonomic distinction of Callicebus torquatus populations (Pitheciidae: Primates) in Peruvian Amazonia. American Journal of Primatology: 70(12): 1181-1186. https://doi. org/10.1002/ajp.20607

Aquino R, Tuesta C, Rengifo E. 2012. Diversidad de mamíferos y sus preferencias por los tipos de hábitats en la cuenca del río Alto Itaya, Amazonía peruana. Revista Peruana de Biología 19(1): 35-42. https://doi.org/10.15381/ rpb.v19i1.785

Aragón AG, Aguirre M. 2014. Distribución de murciélagos (Chiroptera) de la Región Tacna, Perú. Idesia 32: 119-127. https://doi.org/10.4067/S0718$\underline{34292014000100015}$

Arana M, Ramirez L, Ramirez 0. 2005. Cohesión genética en el ratón orejón de los Andes. Mosaico Científico 2(1): 2834 .

Arenas-Vivéros D, Sánchez-Vendizú P, Giraldo A, Salazar-Bravo J. 2021. A new species of Cynomops (Chiroptera: Molossidae) from the northwestern slope of the Andes. Mammalia 85(3): 273-286. https://doi.org/10.1515/ mammalia-2020-0068

Arias E, Pacheco V, Cervantes K, et al. 2016. Diversidad y composición de murciélagos en los bosques montanos del Santuario Nacional Pampa Hermosa, Junín, Perú. Revista Peruana de Biología 23(2): 103-116. https://doi. org/10.15381/rpb.v23i2.12381

Arias E, Pacheco V. 2019. Dieta y estructura trófica de un ensamblaje de murciélagos en los bosques montanos del Santuario Nacional Pampa Hermosa, Junín, Perú. Revista Peruana de Biología 26(2): 169-182. https://doi. org/10.15381/rpb.v26i2.16375

Arrivillaga J, Caraballo V. 2009. Medicina de la Conservación. Revista Biomédica 20(1): 55-67.

Baca-Rosado B. 2017. Odocoileus virginianus (Venado Cola Blanca). Historia natural, problemática y alternativas de aprovechamiento. Mentor Forestal 1(1): 53-57.

Baird AB, Braun JK, Engstrom MD, et al. 2017. Nuclear and mtDNA phylogenetic analyses clarify the evolutionary history of two species of native Hawaiian bats and the taxonomy of Lasiurini (Mammalia: Chiroptera). PLoS ONE 12(10): e0186085. https://doi.org/10.1371/ journal.pone.0186085

Baker RJ, McDonough MM, Swier VJ, et al. 2009. New species of Bonneted bat, genus Eumops (Chiroptera: Molossidae) from the lowlands of western Ecuador and Peru. Acta Chiropterologica 11(1): 1-13. https://doi. org/10.3161/150811009X465659

Barbosa JL, Custódio RJ, Brandao MV. 2015. Rediscovery and range extension of the blackshouldered opossum Caluromysiops irrupta Sanborn, 1951 (Didelphimorphia, Didelphidae) in Brazil. Mammalia 80(3): 325328. https://doi.org/10.1515/mammalia-2014-0147
Bardales-Ordoñez JM. 2015. Diversidad y abundancia de murciélagos (mammalia: Quiroptera) en los bosques del Centro de Investigación y Enseñanza Forestal Puerto Almendra (CIEFOR), Iquitos-Perú. Tesis, Licenciado en Ecología. Facultad de Ciencias e Ingeniería Universidad Científica del Perú. Acceso 15/06/2021. <http://repositorio.ucp.edu.pe/bitstream/handle/UCP/350/BARDALES-1-Trabajo-Diversidad. pdf? sequence $=1 \&$ is Allowed $=y>$

Barkley LJ. 2008. Genus Glironia O. Thomas, 1912. Pp. 12-14. En: Gardner AL, Ed. Mammals of South America, Volume 1: Marsupials, Xenarthrans, Shrews, and Bats. The University of Chicago Press, Chicago, IL, USA. xx + 669 pp.

Barrio J. 2006. Manejo no intencional de dos especies de cérvidos por exclusión de ganado en la parte alta del Parque Nacional Río Abiseo, Perú. Revista Electrónica Manejo de Fauna Silvestre en Latinoamérica 1(2): 1-10.

Barrio J. 2010. First records and conservation status of Mazama rufina (Cervidae, Artiodactyla) from Perú. Mastozoología Neotropical 17(1): 117-122.

Basantes M, Tinoco N, Velazco PM, et al. 2020. Systematics and taxonomy of Tonatia saurophila Koopman \& Williams, 1951 (Chiroptera, Phyllostomidae). ZooKeys 915: 5986. https://doi.org/10.3897/zookeys.915.46995

Bidau CJ. 2015. Family Ctenomyidae Lesson, 1842. Pp. 818-877. En: JL Patton, UFJ Pardiñas y G D'Elía, eds. Mammals of South America, Volume 2: Rodents. The University of Chicago Press, Chicago, IL, USA. xxvi + 1336 pp.

Boddicker M, Rodríguez JJ, Amanzo J. 2001. Assessment of the large mammals of the lower Urubamba region, Peru. Pp: 183-194. En: A Alonso, F Dallmeier y P Campbell, eds. Urubamba: The biodiversity of a Peruvian rainforest. SI/MAB Series $N^{\circ} 7$, Smithsonian Institution/ MAB Biodiversity Program, Washington DC, USA. 195 pp.

Bonvicino CR, Weksler M. 2015. Genus Nectomys Peters, 1861. Pp. 369-377. En: JL Patton, UFJ Pardiñas y G D'Elía, eds. Mammals of South America, Volume 2: Rodents. The University of Chicago Press, Chicago, IL, USA. xxvi $+1336 \mathrm{pp}$.

Bornholdt R, Helgen K, Koepfli KP, et al. 2013. Taxonomic revision of the genus Galictis (Carnivora: Mustelidae): species delimitation, morphological diagnosis, and refined mapping of geographical distribution. Zoological Journal of the Linnean Society 167(3): https:// doi.org/10.1111/i.1096-3642.2012.00859.x

Brack-Egg E. 1986. Las ecorregiones del Perú. Boletín de Lima 44: 57-70.

Bravo A, Borman R. 2008. Mamíferos. Pp: 105-111. En: WS Alverson, C Vriesendorp, A del Campo, et al., eds. Ecuador-Perú: Cuyabeno-Güeppí. Rapid Biological and Social Inventories Report 20. The Field Museum, Chicago, IL, USA. 149 pp.

Bravo A. 2010. Mamíferos. Pp 90-96. En: MP Gilmore, C Vriesendorp y WS Alverson, eds. 2010. Perú: Maijuna. Rapid Biological and Social Inventories Report 22. The Field Museum, Chicago, IL, USA. 140 pp.

Brito J, Tinoco N, Burneo S, et al. 2021. A new species of Spiny mouse, genus Neacomys (Cricetidae: Sigmodontinae) from Cordillera del Cóndor, Ecuador. Mastozoologia Neotropical 28(1): 1-22. https://doi.org/10.31687/ saremMN.21.28.1.0.23

Bryant FC, Farfan RD. 1984. Dry season forage selection by alpaca [Lama pacos] in southern Peru. Journal of 
Range Management 37(4): 330-333. https://doi. org/10.2307/3898705

Burgin CJ, Colella JP, Kahn PL, et al. 2018. How many species of mammals are there? Journal of Mammalogy 99(1): 1-14. https://doi.org/10.1093/jmammal/gyx147

Calahorra-Oliart A, Ospina-Garcés SM, León-Paniagua L. 2021. Cryptic species in Glossophaga soricina (Chiroptera: Phyllostomidae): do morphological data support molecular evidence? Journal of Mammalogy 102(1): 5468. https://doi.org/10.1093/jmammal/gyaa116

Calderón W, Pacheco V. 2012. First report of Artibeus bogotensis Andersen, 1906 (Chiroptera: Phyllostomidae) for Peru. Check List 8(6): 1333-1336. https://doi. org/10.15560/8.6.1333

Calderón-Acevedo C, Muchhala N. 2020. First report of the Broad-toothed tailless bat, Anoura latidens Handley, 1984 (Chiroptera, Phyllostomidae), in Bolivia. Check List 16(6): 1545-1550. https://doi org/10.15560/16.6.1545

Calderón-Acevedo C, Rodríguez-Posada M, Muchhala N. 2021. Morphology and genetics concur that Anoura carishina is a synonym of Anoura latidens (Chiroptera, Glossophaginae). Mammalia 85(5): 471-481. https://doi. org/10.1515/mammalia-2020-0183

Calizaya-Mamani GE. 2017. Diversidad y distribución del orden Chiroptera en una gradiente altitudinal en la cuenca del río Locumba, provincia de Jorge Basadre-Tacna. Tesis, Licenciado en Biología Microbiología. Facultad de Ciencias Universidad Nacional Jorge Basadre Grohmann. Acceso 16/06/2021. <http://repositorio.unjbg. edu.pe/bitstream/handle/UNJBG/1965/1189_2017_ calizaya_mamani_ge_faci_biologia_microbiologia. pdf?sequence $=1$ \&isAllowed $=y>$

Carleton MD, Musser GG. 1989. Systematic studies of Oryzomyine rodents (Muridae, Sigmodontinae): a synopsis of Microryzomys. Bulletin of the American Museum of Natural History 191: 1-83

Carleton MD, Musser GG. 2015. Genus Oecomys Thomas, 1906. Pp. 393-417. En: JL Patton, UFJ Pardiñas y G D'Elía, eds. Mammals of South America, Volume 2: Rodents. The University of Chicago Press, Chicago, IL, USA. xxvi $+1336 \mathrm{pp}$

Carleton MD. 2015 Genus Transandinomys Weksler, Percequillo, and Voss 2006. Pp. 456-460. En: JL Patton, UFJ Pardiñas y G D'Elía, eds. Mammals of South America, Volume 2: Rodents. The University of Chicago Press, Chicago, IL, USA. xxvi + 1336 pp.

Carrasco-Rueda F, Loiselle BA. 2020. Dimensions of phyllostomid bat diversity and assemblage composition in a tropical forest-agricultural landscape. Diversity 12(6): 1-30. https://doi.org/10.3390/d12060238

Castillo D, Chávez V, Hoces R, et al. 2008. Contribución al estudio del parasitismo gastrointestinal en guanacos (Lama guanicoe cacsilensis). Revista de Investigaciones veterinarias del Perú 19(2): 168-175. https://doi org/10.15381/rivep.v19i2.1164

Castro MC, Ciancio MR, Pacheco V, et al. 2015. Reassessment of the hairy long-nosed armadillo "Dasypus" pilosus and revalidation of the genus Cryptophractus Fitzinger, 1856. Zootaxa 3947(1): 30-48. https://doi. org/10.11646/zootaxa.3947.1.2

Catzeflis F, Tilak MK. 2009. Molecular systematics of Neotropical spiny mice (Neacomys: Sigmodontinae, Rodentia) from the Guianan Region. Mammalia 73(3): 239-247. https://doi.org/10.1515/MAMM.2009.037
Cossíos ED, Alcázar P, Fajardo U, et al. 2012. El orden Carnivora (Mammalia) en el Perú: Estado del conocimiento y prioridades de investigación para su conservación. Revista Peruana de Biología 19(1): 17-26. https://doi. org/10.15381/rpb.v19i1.783

Cossíos ED, Madrid A, Condori JL, et al. 2007. Update on the distribution of the Andean cat Oreailurus jacobita and the pampas cat Lynchailurus colocolo in Peru. Endangered Species Research 3(3): 313-320. https://doi. org/10.3354/esr00059

Cossíos ED. 2010. Lycalopex sechurae (Carnivora: Canidae). Mammalian Species 42(848): 1-6. https://doi. org/10.1644/848.1

Cossíos ED. 2010. Vertebrados naturalizados en el Perú: historia y estado del conocimiento. Revista Peruana de Biología 17(2): 179-189. https://doi.org/10.15381/ rpb.v17i2.25

Cristofanelli S, Antonini M, Torres D, et al. 2004. Meat and carcass quality from Peruvian llama (Lama glama) and alpaca (Lama pacos). Meat Science 66(3): 589-593. https://doi.org/10.1016/S0309-1740(03)00174-8

Chiquito EA, Percequillo AR. 2017. On the rare species Amphinectomys savamis Malygin 1994 (Rodentia, Cricetidae, Sigmodontinae): new record and morphological considerations. Mammalia 81(5): 531-536. https:// doi.org/10.1515/mammalia-2016-0101

Chiquito EA, Percequillo AR. 2019. The taxonomic status of Nectomys saturatus Thomas, 1897 (Cricetidae: Sigmodontinae). Zootaxa 4550(3): 321-339. https://doi. org/10.11646/zootaxa.4550.3.2

de la Sancha NU, López-González C, D'Elia G, et al. 2017. An annotated checklist of the mammals of Paraguay. Therya 8(3): 241-260. https://doi.org/10.12933/ therya-17-473

de Oliveira J, Gonçalves PR. 2015. Genus Oxymycterus (Waterhouse, 1837). Pp. 247-278. En: JL Patton, UFJ Pardiñas y G D'Elía, eds. Mammals of South America, Volume 2: Rodents. The University of Chicago Press, Chicago, IL, USA. xxvi + 1336 pp.

de Vivo M, Carmignotto AP. 2015. Family Sciuridae (G. Fisher, 1817). Pp. 3-47. En: JL Patton, UFJ Pardiñas y G D'Elía, eds. Mammals of South America, Volume 2: Rodents. The University of Chicago Press, Chicago, IL, USA. xxvi $+1336 \mathrm{pp}$

D'Elía G, Canto J, Ossa G, et al. 2020. Lista actualizada de los mamíferos vivientes de Chile. Boletín del Museo Nacional de Historia Natural, Chile 69(2): 67-98.

Díaz MM, Linares-García VH. 2012. Refugios naturales y artificiales de murciélagos (Mammalia: Chiroptera) en la selva baja en el noroeste de Perú. Gayana 76(2): 117-30. https://doi.org/10.4067/S071765382012000300005

Díaz MM, Willig MR. 2004. Nuevos registros de Glironia venusta y Didelphis albiventris (Didelphimorphia) para Perú. Mastozoología Neotropical 11(2): 185-192.

Díaz MM. 2011. New records of bats from the northern region of the Peruvian Amazon. Zoological Research 32(2): 168-178. https://dx.doi.org/10.3724/ SP.J.1141.2011.02168

Díaz-Nieto JF, Jansa SA, Voss RS. 2016. DNA sequencing reveals unexpected recent diversity and an ancient dichotomy in the American marsupial genus Marmosops (Didelphidae: Thylamyini). Zoological Journal of the Linnean Society 176(4): 914-940. https://doi.org/10.1111/ zoj.12343 
Díaz-Nieto JF, Voss RS. 2016. A revision of the Didelphid Marsupial Genus Marmosops, Part 1: Species of the subgenus Sciophanes. Bulletin of the American Museum of Natural History 402: 1-70. https://doi.org/10.1206/0003$\underline{0090-402.1 .1}$

Divoll T, Kumar A, Flores-Negron C, Hurtado C. 2015. Maternity roost of Eptesicus brasiliensis in a liana in the southeast Peruvian Amazon. Mastozoología Neotropical 22(1): 155-161.

Dragoo JW, Honeycutt RL, Schmidly DJ. 2003. Taxonomic status of white-backed hog-nosed skunks, genus Conepatus (Carnivora: Mephitidae). Journal of Mammalogy 84(1): 159-176. https://doi. org/10.1644/1545-1542(2003)084<0159:TSOWBH $>2.0 . \mathrm{CO} ; 2$

DS N 004-2014-AG. 2014. Decreto Supremo que aprueba la actualización de la lista de clasificación y categorización de las especies amenazadas de fauna silvestre legalmente protegidas, Ministerio de Agricultura y Riego. 8 de abril del 2014. El Peruano Normas Legales: 520497-520504.

DS N 019-2021-MINAM. 2021. Decreto Supremo que aprueba el Reglamento de acceso a los recursos genéticos y sus derivados, Ministerio del Ambiente. 24 de julio del 2021. El Peruano Normas Legales: 35-50.

Dunnum JL, J. Salazar-Bravo J. 2010. Phylogeny, evolution, and systematics of the Galea musteloides complex (Rodentia: Caviidae). Journal of Mammalogy 91: 243-259. https://doi.org/10.1644/08-MAMM-A-214R1.1

Dunnum JL. 2015. Family Caviidae G. Fischer, 1817. Pp. 690-726. En: JL Patton, UFJ Pardiñas y G D'Elía, eds. Mammals of South America, Volume 2: Rodents. The University of Chicago Press, Chicago, IL, USA. xxvi + 1336 pp.

Elías R, Berenguel R, Beraún Y, et al. 2020. Gestión y vigilancia sanitaria de la fauna silvestre en el Perú. Salud y Tecnología Veterinaria 1: 19-26. https://doi.org/10.20453/ $\underline{\text { stv.v8i1.3788 }}$

Emmons LH, Fabre P-H. 2018. A review of the Pattonomys/ Toromys Clade (Rodentia: Echimyidae), with descriptions of a new Toromys species and new genus. American Museum Novitates 3894: 1-52. https://doi. org/10.1206/3894.1

Emmons LH, Leite YLR, Patton JL. 2015b. Genus Echimys F. Cuvier, 1809. Pp. 893-898. En: JL Patton, UFJ Pardiñas y G D'Elía, eds. Mammals of South America, Volume 2: Rodents. The University of Chicago Press, Chicago, IL, USA. xxvi + 1336 pp.

Emmons LH, Patton JL, Leite YLR. 2015a. Subfamily Dactylomyinae Tate, 1935. Pp. 880-888. En: JL Patton, UFJ Pardiñas y G D'Elía, eds. Mammals of South America, Volume 2: Rodents. The University of Chicago Press, Chicago, IL, USA. xxvi + 1336 pp.

Emmons LH, Patton JL. 2015. Genus Makalata Husson, 1978. Pp. 905-910. En: JL Patton, UFJ Pardiñas y G D'Elía, eds. Mammals of South America, Volume 2: Rodents. The University of Chicago Press, Chicago, IL, USA. xxvi + 1336 pp.

Emmons LH, Romo M, Luna L, et al. 2002. Anexo 4. Comparación de ocurrencia de especies de mamíferos del Santuario Nacional Pampas del Heath (RAP 1992 y RAP 1996) con otras localidades de Madre de Dios. Pp. 106-110. En: JR Montambault, ed. 2002. Informes de las evaluaciones biológicas Pampas del Heath, Perú; Alto Madidi, Bolivia; y Pando, Bolivia. Conservation International, Bulletin of Biological Assessment 24. Washington DC, USA. 125 pp.
Emmons LH. 1999. A new genus and species of abrocomid rodent from Peru (Rodentia: Abrocomidae). American Museum Novitates 3279: 1-14.

Escamilo L, Barrio J, Benavides J, et al. 2010. Northern Pudu, Pudu mephistophiles (de Winton, 1896). Pp. 133-139. En: J Duarte y S Gonzales, eds. Neotropical cervidology: biology and medicine of Latin American deer. Jaboticabal, Brazil: Funep and Gland, Switzerland: IUCN. $393 \mathrm{pp}$.

Escobedo M, Velazco PM. 2012. First confirmed record for Peru of Diclidurus scutatus Peters, 1869 (Chiroptera: Emballonuridae). Check List 8(3): 554-556. https://doi. org/10.15560/8.3.554

Escobedo M. 2003. Murciélagos. Pp. 82-84. En: N Pitman, C Vriesendorp, D Moskovits, et al., eds. Perú: Yavarí. Rapid Biological and Social Inventories Report 11. The Field Museum, Chicago, IL, USA. 185 pp.

Escobedo M. 2015. Mamíferos. Pp. 142-151. En: N Pitman, C Vriesendorp, L Rivera-Chávez, et al., eds. Perú: TapicheBlanco. Rapid Biological and Social Inventories Report 27. The Field Museum, Chicago, IL, USA. 505 pp.

Fajardo U, Cossíos D, Pacheco V. 2014. Dieta de Leopardus colocolo (Carnivora: Felidae) en la Reserva Nacional de Junín, Junín, Perú. Revista Peruana de Biología 21(1): 61-70. https://doi.org/10.15381/rpb.v21i1.8248

Falcão F, Ugarte J, Faria D, Caselli C. 2015. Unravelling the calls of discrete hunters: acoustic structure of echolocation calls of furipterid bats (Chiroptera: Furipteridae). Bioacoustics 24(2): 175-183. https://doi.org/10.1080/0 9524622.2015.1017840

Feng X, Castro MC, McBee K, et al. 2017. Hiding in a Cool Climatic Niche in the Tropics? An assessment of the ecological biogeography of Hairy long-nosed armadillos (Dasypus Pilosus). Tropical Conservation Science 10: 1-13. https://doi.org/10.1177/1940082917697249

Fernandez-Arellano G, Torres-Vásquez GM. 2013. Lista actualizada de quirópteros de los departamentos de Loreto, Ucayali y Madre de Dios (Perú). Barbastella 6(1): 7388. https://doi.org/10.14709/Barb].6.1.2013.10

Fleck DW, Harder JD. 2000. Matses Indian rainforest habitat classification and mammalian diversity in Amazonian Peru. Journal of Ethnobiology 20(1): 1-36.

Flores DA, Barquez RM, Díaz MM. 2008. A new species of Philander Brisson, 1762 (Didelphimorphia, Didelphidae). Mammalian Biology 73(1): 14-24. https://doi. org/10.1016/j.mambio.2007.04.002

Flores-Quispe M, Calizaya-Mamani G, Pacheco V, Aragon-Alvarado G. 2015. Distribution of Promops davisoni Thomas, 1921 (Chiroptera: Molossidae) in Peru with a new record and southward range extension. Check List 11(2): 1-7. https://doi.org/10.15560/11.2.1573

Flores-Quispe M, Calizaya-Mamani G, Portugal-Zegarra G, et al. 2019. Contributions to the natural history of Mormopterus kalinowskii (Chiroptera: Molossidae) in the southwest of Peru. Therya 10(3): 343-352. https:// doi.org/10.12933/therya-19-753

Garbino GS, Casali DM, Nascimento FO, et al. 2019. Taxonomy of the Pygmy marmoset (Cebuella Gray, 1866): Geographic variation, species delimitation, and nomenclatural notes. Mammalian Biology 95: 135-142. https:// doi.org/10.1016/j.mambio.2018.09.003

García-Olaechea A, Appleton RD, Piana RP. 2019. First confirmed record of jaguarundi, Herpailurus yagouaroundi (É. Geoffroy, 1803) (Mammalia, Carnivora, Felidae), on the western slope of the Peruvian Andes. Check List 


\section{5(5): 875-878. https://doi.org/10.15560/15.5.875}

García-Olaechea A, Chávez-Villavicencio C, Cova JN. 2013. Leopardus pajeros (Desmarest, 1816) (Carnivora: Felidae) in northern Peru: first record for the department of Piura, at the mangroves San Pedro de Vice, and geographic extension. Check List 9(6): 1596-1599. https://doi.org/10.15560/9.6.1596

Gardner AL, ed. Mammals of South America, Volume 1: Marsupials, Xenarthrans, Shrews, and Bats. The University of Chicago Press, Chicago, IL, USA. xx + 669 pp.

Gardner AL, Romo M. 1993. A new Thomasomys (Mammalia: Rodentia) from the Peruvian Andes. Proceedings of the Biological Society of Washington 106(4): 762-74.

Giarla TC, Voss RS, Jansa SA. 2010. Species limits and phylogenetic relationships in the didelphid marsupial genus Thylamys based on mitochondrial DNA sequences and morphology. Bulletin of the American Museum of Natural History 346: 1-67. https://doi. org/10.1206/716.1

Giménez AL, Giannini NP, Almeida FC. 2019. Mitochondrial genetic differentiation and phylogenetic relationships of three Eptesicus (Histiotus) species in a contact zone in Patagonia. Mastozoología Neotropical 26(2): 349-358. https://doi.org/10.31687/saremMN.19.26.2.0.10

Gomes R, Fonseca C, Zhou Z, et al. 2012. Taxonomic and conservation status of the elusive Oecomys cleberi (Rodentia, Sigmodontinae) from central Brazil. Mammalian Biology 77(6): 414-419. https://doi.org/10.1016/i. mambio.2012.02.004

Gonçalves PR, Teta P, Bonvicino CR. 2015. Genus Holochilus Brandt, 1835. Pp. 325-335. En: JL Patton, UFJ Pardiñas y G D'Elía, eds. Mammals of South America, Volume 2: Rodents. The University of Chicago Press, Chicago, IL, USA. xxvi + 1336 pp.

Gonzales FN, Llerena G. 2014. Cacería de mamíferos en la zona de uso especial y de amortiguamiento del Parque Nacional Tingo María, Huánuco, Perú. Revista Peruana de Biología 21(3): 283-286. https://doi.org/10.15381/ rpb.v21i3.10904

González EM, Lessa EP. 2014. Historia de la Mastozoología en Uruguay. Pp. 381-404. En: J Ortega, JL Martínez y DG Tirira, eds. Historia de la mastozoología en Latinoamérica, las Guayanas y el Caribe. Editorial Murciélago Blanco y Asociación Ecuatoriana de Mastozoología, Quito y México, DF. 448 pp.

González-Ruiz N, Ramírez-Pulido J, Arroyo-Cabrales J. 2011. A new species of Mastiff bat (Chiroptera: Molossidae: Molossus) from Mexico. Mammalian Biology 76(4): 461-469. https://doi.org/10.1016/j.mambio.2010.06.004

Gregorin R, Chiquito EA. 2010. Revalidation of Promops davisoni Thomas (Molossidae). Chiroptera Neotropical 16(1): 648-660.

Gregory T, Lunde D, Zamora-Meza HT, Carrasco-Rueda F. 2015. Records of Coendou ichillus (Rodentia, Erethizontidae) from the lower Urubamba region of Peru. ZooKeys 509: 109-121. https://doi.org/10.3897/ zookeys.509.9821

Gregory T, Portillo A, Cadenillas R, et al. 2016. Madre de Dios, Perú. Mammals of the Amarakaeri Communal Reserve. Smithsonian Conservation Biology Institute. Pp. 1-3.

Gregory T, Rueda FC, Deichmann JL, et al. 2012. Primates of the Lower Urubamba Region, Peru, with comments on other mammals. Neotropical Primates 19(1): 16-24. https://doi.org/10.1896/044.019.0103
Gutiérrez EE, Helgen KM, McDonough MM, et al. 2017. A gene-tree test of the traditional taxonomy of American deer: the importance of voucher specimens, geographic data, and dense sampling. ZooKeys 697: 87-131. https://doi.org/10.3897/zookeys.697.15124

Hafner MS, Barkley LJ, Chupasko JM. 1994: Evolutionary genetics of New World tree squirrels (Tribe Sciurini). Journal of Mammalogy 75: 102-109. https://doi. org/10.2307/1382241

Helgen KM, Pinto CM, Kays R, et al. 2013. Taxonomic revision of the olingos (Bassaricyon) with description of a new species, the Olinguito. ZooKeys 324: 1-83. https://doi. org/10.3897/zookeys.324.5827

Heymann EW, Encarnación F, Canaquin JE. 2002. Primates of the río Curaray, northern Peruvian Amazon. International Journal of Primatology 23(1): 191-201. https:// doi.org/10.1023/A:1013262210863

Hice CL, Solari S. 2002. First record of Centronycteris maximiliani (Fischer, 1829) and two additional records of C. centralis Thomas, 1912 from Peru. Acta Chiropterologica 4(2): 217-220. https://doi. org/10.3161/001.004.0209

Hice CL, Velazco PM, Willig MR. 2004. Bats of the Reserva Nacional Allpahuayo-Mishana, northeastern Peru, with notes on community structure. Acta Chiropterologica 6(2): 319-334. https://doi.org/10.3161/001.006.0210

Hice CL, Velazco PM. 2012. The non-volant mammals of the Reserva Nacional Allpahuayo-Mishana, Loreto, Peru. Special Publications of the Museum of Texas Tech University 60: 1-135. https://doi.org/10.5962/bhl. title.156875

Huamaní L, Cadenillas R, Pacheco V. 2009. Primer registro de Gracilinanus agilis (Burmeister, 1854) (Mammalia: Didelphidae) para Loreto, Perú. Revista Peruana de Biología 16(2): 219-220. https://doi.org/10.15381/ rpb.v16i2.210

Hurtado CM, Pacheco V, Fajardo Ú, et al. 2016b. An updated analysis of the distribution of Cites-listed Peruvian carnivores for conservation priorities. Mastozoología Neotropical 23(2): 415-429.

Hurtado CM, Pacheco V. 2015. New mammalian records in the Parque Nacional Cerros de Amotape, northwestern Peru. Revista Peruana de Biología 22(1): 77-86. https://doi.org/10.15381/rpb.v22i1.11124

Hurtado CM, Serrano-Villavicencio J, Pacheco V. 2016a. Population density and primate conservation in the Noroeste Biosphere Reserve, Tumbes, Peru. Revista Peruana de Biología 23(2): 151-158. https://doi.org/10.15381/ rpb.v23i2.12423

Hurtado N, Arias E, Pacheco V. 2014. Redescription of Mimon koepckeae (Chiroptera: Phyllostomidae). Zoologia 31(4): 377-88. https://doi.org/10.1590/S1984$\underline{46702014000400009}$

Hurtado N, D'Elia G. 2018. Taxonomy of the genus Gardnerycteris (Chiroptera: Phyllostomidae). Acta Chiropterologica 20(1): 99-115. https://doi.org/10.3161/150811 09ACC2018.20.1.007

Hurtado N, D'Elía G. 2019. An assessment of species limits of the South American mouse genus Oligoryzomys (Rodentia, Cricetidae) using unilocus delimitation methods. Zoologica Scripta 48(5): 557-570. https:// doi.org/10.1111/zsc.12365

Hurtado N, Pacheco V. 2014. Análisis filogenético del género Mimon Gray, 1847 (Mammalia, Chiroptera, Phyllostomidae) con la descripción de un nuevo género. 
Therya 5(3): 751-779. https://doi.org/10.12933/ therya-14-230

Hurtado N, Pacheco V. 2017. Revision of Neacomys spinosus (Thomas, 1882) (Rodentia: Cricetidae) with emphasis on Peruvian populations and the description of a new species. Zootaxa 4242: 401-440. https://doi. org/10.11646/zootaxa.4242.3.1

Hurtado N, Sepúlveda RD, Pacheco V. 2015. Sexual size dimorphism of a sensory structure in a monomorphic bat. Acta Chiropterologica 17(1): 75-83. https://doi.org/1 $\underline{0.3161 / 15081109 A C C 2015.17 .1 .006}$

Hurtado N. 2021. A new species of the genus Oligoryzomys (Rodentia: Cricetidae) from Peru. Journal of Mammalogy 102(3): 931-946. https://doi.org/10.1093/ ¡mammal/gyab030

Inche-Arroyo BD. 2019. Estado taxonómico de Akodon aerosus baliolus (Cricetidae: sigmodontinae). Tesis, Licenciado en Biología con mención en Zoología. Facultad de Ciencias Biológicas Universidad Nacional Mayor de San Marcos. Acceso 31/07/2021. $<$ https://cybertesis.unmsm.edu.pe/bitstream/handle/20.500.12672/10370/Inche_ab.pdf?sequence=3\& isAllowed $=\mathrm{y}>$.

Jayat JP, Ortiz PE, Salazar-Bravo J, et al. 2010. The Akodon boliviensis species group (Rodentia: Cricetidae: Sigmodontinae) in Argentina: species limits and distribution, with the description of a new entity. Zootaxa 2409(1): 1-61. https://doi.org/10.11646/zootaxa.2409.1.1

Jefferson TA, Leatherwood S, Webber MA. 1993. FAO Species identification guide. Marine mammals of the world. Food and Agriculture Organization of the United Nations, Viale delle Terme di Caracalla, Rome, Italy. 320 pp.

Jiménez CF, Pacheco V, Vivas D. 2013. An introduction to the systematics of Akodon orophilus Osgood, 1913 (Rodentia: Cricetidae) with the description of a new species. Zootaxa 3669: 223-242. https://doi.org/10.11646/ zootaxa.3669.3.2

Jiménez CF, Pacheco V. 2012. Nuevo registro de Rhipidomys (Rodentia: Sigmodontinae) del grupo fulviventer de los bosques montanos de Amazonas, Perú. Presentado en el III Congreso Peruano de Mastozoología, 14-18 Octubre 2012.

Jiménez CF, Pacheco V. 2016. A new species of grass mouse, genus Akodon Meyen, 1833 (Rodentia, Sigmodontinae), from the central Peruvian Yungas. Therya 7: 449-464. https://doi.org/10.12933/therya-16-336

Jiménez CF, Quintana H, Pacheco V, et al. 2010. Camera trap survey of medium and large mammals in a montane rainforest of northern Peru. Revista Peruana de Biología 17(2): 191-196.

Jiménez-Ortega A, Mantilla-Meluk H. 2011. Noteworthy records of Lionycteris spurrelli (Chiroptera: Phyllostomidae) (Thomas 1913) from British Guiana and Colombia. Investigación, Biodiversidad y Desarrollo 30(2): 101109. https://doi.org/10.18636/ribd.v30i2.299

Jorge MLSP, Velazco PM. 2006. Mamíferos. Pp. 98-106. En: C Vriesendorp, TS Schulenberg, WS Alverson, et al., eds. Perú: Sierra del Divisor. Rapid Biological and Social Inventories Report 17. The Field Museum, Chicago, IL, USA. 120 pp.

Juárez-Pérez Y, Sánchez-Vendizú P, Leo M, et al. 2021. First records of Echimys saturnus Thomas, 1928 (Rodentia, Echimyidae) for the Peruvian Yungas. Check List 17(3): 1007-1014. https://doi.org/10.15560/17.3.1007
Klingbeil B, Willig R. 2010. Seasonal differences in population-ensemble, and community-level responses of bats to landscape structure in Amazonia. Oikos 119: 1654-1664. https://doi.org/10.1111/j.16000706.2010.18328.x

Lanzone C, Braun JK, Patton JL, et al. 2015. Genus Eligmodontia F. Cuvier, 1837. Pp. 508-521. En: JL Patton, UFJ Pardiñas y G D'Elía, eds. Mammals of South America, Volume 2: Rodents. The University of Chicago Press, Chicago, IL, USA. xxvi + 1336 pp.

Larsen PA, Siles L, Pedersen S, Kwiecinski G. 2011. A new species of Micronycteris (Chiroptera: Phyllostomidae) from Saint Vincent, Lesser Antillas. Mammalian Biology. 76: 687-700. https://doi.org/10.1016/j.mambio.2011.01.006

Lim BK, Catzeflis FM. 2014. History of mammalogy in the Guianas. Pp. 265-292. En: J Ortega, JL Martínez y DG Tirira, eds. Historia de la mastozoología en Latinoamérica, las Guayanas y el Caribe. Editorial Murciélago Blanco y Asociación Ecuatoriana de Mastozoología, Quito y México, DF. 448 pp.

Lim BK, Engstrom MD, Reid FA, et al. 2010. A new species of Peropteryx (Chiroptera: Emballonuridae) from western Amazonia with comments on phylogenetic relationships within the genus. American Museum Novitates 3686: 1-20. https://doi.org/10.1206/691.1

Loaiza C, Pacheco V. 2017. Modelamiento predictivo, distribución geográfica y estado de conservación de Tomopeas ravus Miller, 1900 (Chiroptera, Molossidae). Revista Peruana de Biología 24(2): 193-198. https://doi. org/10.15381/rpb.v24i2.13495

Loaiza C, Salas J, Hing A. 2020. Could a new record change the range of distribution of a little-known bat species (Vespertilionidae: Eptesicus innoxius)? Therya 11(1): 143-150. https://doi.org/10.12933/therya-20-700

López-Urbina MT, González AE, Gomez-Puerta LA, et al. 2009. Prevalence of neonatal cryptosporidiosis in Andean alpacas (Vicugna pacos) in Peru. Open Parasitology Journal 3(1): 9-13. https://doi. org/10.2174/1874421400903010009

Loureiro L, Engstrom M, Lim B, et al. 2019. Not all Molossus are created equal: genetic variation in the mastiff bat reveals diversity masked by conservative morphology. Acta Chiropterologica 21(1): 51-64. https://doi.org/1 $\underline{0.3161 / 15081109 A C C 2019.21 .1 .004}$

Ludeña JP, Medina CE. 2017. Segundo registro de Cyttarops alecto y Eumops wilsoni (Mammalia: Chiroptera) en el Perú. Revista Peruana de Biología 24(4): 401-406. https://doi.org/10.15381/rpb.v24i4.14065

Luna L, Pacheco V. 2002. A new species of Thomasomys (Muridae: Sigmodontinae) from the Andes of southeastern Peru. Journal of Mammalogy 83(3): 834-842. https:// doi.org/10.1644/1545-1542(2002)083<0834:ANSO $\mathrm{TM}>2.0 . \mathrm{CO} ; 2$

Luna L, Patterson BD. 2003. A remarkable new mouse (Muridae: Sigmodontinae) from southeastern Peru, with comments on the affinities of Rhagomys rufescens (Thomas, 1886). Fieldiana: Zoology, new series 101: 1-24. https://doi.org/10.5962/bhl.title.3529

Lunde D, Pacheco V. 2003. Shrew opossums (Paucituberculata: Caenolestes) from the Huancabamba region of east Andean Peru. Mammal Study 28(2): 145-148. https:// doi.org/10.3106/mammalstudy.28.145

Lynch-Alfaro JW, Boubli JP, Olson LE, et al. 2012. Explosive Pleistocene range expansion leads to widespread Amazo- 
nian sympatry between robust and gracile Capuchin monkeys. Journal of Biogeography 39(2): 272-288. https://doi.org/10.1111/j.1365-2699.2011.02609.x

Lynch-Alfaro JW, Boubli JP, Paim FP, et al. 2015. Biogeography of Squirrel monkeys (Genus Saimiri): South-central Amazon origin and rapid pan-Amazonian diversification of a lowland primate. Molecular Phylogenetics and Evolution 82: 436-454. https://doi.org/10.1016/i. ympev.2014.09.004

Maguiña R, Amanzo J. 2016. Diet and pollinator role of the Longsnouted bat Platalina genovensium in lomas ecosystem of Peru. Tropical Conservation Science 9(4): 1-8. https://doi.org/10.1177/1940082916674288

Málaga BA, Díaz DR, Arias S, Medina CE. 2020. Una especie nueva de Lasiurus (Chiroptera: Vespertilionidae) del suroeste de Perú. Revista Mexicana de Biodiversidad 91: e913096. https://doi.org/10.22201/ ib.20078706e.2020.91.3096

Mantilla-Meluk H, Perez-Amaya N, Velazco PM. 2019. Morphometric variation of the genus Lonchorhina (Chiroptera, Lonchorhininae), with noteworthy comments on taxonomy and distributional range extensions. Pp. 149-168. En: RD Bradley, HH Genoways, DJ Schmidly y LC Bradley, eds. From field to laboratory: a memorial volume in honor of Robert J. Baker. Special Publications, Museum of Texas Tech University 71: xi + 1-911.

Marín JC, Casey CS, Kadwell M, et al. 2007. Mitochondrial phylogeography and demographic history of the vicuna: implications for conservation. Heredity 99(1): 70-80. https://doi.org/10.1038/sj.hdy.6800966

Marín JC, Spotorno AE, González BA, et al. 2008. Mitochondrial DNA variation and systematics of the guanaco (Lama guanicoe, Artiodactyla: Camelidae). Journal of Mammalogy 89(2): 269-281. https://doi.org/10.1644/06MAMM-A-385R.1

Marmontel M, Weber FC, Kendall S. 2012. The Amazonian manatee. Pp. 47-53. En: EM Hines, JE Reynolds, L Aragones, et al., eds. Sirenian conservation: issues and strategies in developing countries. University Press of Florida, USA. xiv + 326 pp. https://doi.org/10.2307/j. ctvx079z0.11

Marsh LK. 2014. A taxonomic revision of the Saki monkeys, Pithecia Desmarest, 1804. Neotropical Primates 21(1): 1-165. https://doi.org/10.1896/044.021.0101

Maryanto I, Maharadatunkamsi D, Achmadi AS, et al. 2019. Checklist of the mammals of Indonesia: Scientific, English, Indonesia name and distribution area table in Indonesia including CITES, IUCN and Indonesian category for conservation. Research center for Biology, Indonesian Institute of Sciences (LIPI). 3ra ed. Bogor, Indonesia. ix+ $66 \mathrm{pp}$.

Matauschek C, Roos C, Heymann EW. 2011. Mitochondrial phylogeny of tamarins (Saguinus Hoffmannsegg 1807) with taxonomic and biogeographic implications for the S. nigricollis species group. American Journal of Physical Anthropology 144(4): 564-574. https:// doi.org/10.1002/ajpa.21445

McAfee RK. 2015. Dental anomalies within extant members of the mammalian Order Pilosa. Acta Zoologica 96(3): 301-311. https://doi.org/10.1111/azo.12077

McHugh SM, Cornejo FM, McKibben J, et al. 2019. First record of the Peruvian yellow-tailed woolly monkey Lagothrix flavicauda in the Región Junín, Peru. Oryx 54(6): 1-5. https://doi.org/10.1017/S003060531900084X

McNeely J, Miller K, Reid W, et al. 1990. Conserving the World's
Biological Diversity. IUCN, Gland, Switzerland; WRI, CI, WWF-US, and the World Bank, Washington, DC. $193 \mathrm{pp}$.

Medina C, Díaz C, Delgado F, et al. 2009. Dieta de Conepatus chinga (Carnívora: Mephitidae) en un bosque de Polylepis del departamento de Arequipa, Perú. Revista Peruana de Biología 16(2): 183-186. https://doi. org/10.15381/rpb.v16i2.203

Medina CE, Díaz D, Málaga B, et al. 2018. Short communication: Second record of Eumops chiribaya (Chiroptera, Molossidae) in Peru. Biodiversitas 19(6): 1979-1984. https://doi.org/10.13057/biodiv/d190601

Medina CE, Díaz DR, Medina YK, et al., eds. 2021. Mamíferos de Arequipa: ¿Cuántos y dónde? Museo de Historia Natural de la Universidad Nacional de San Agustín de Arequipa (MUSA). Arequipa, Perú. 93 pp.

Medina CE, Díaz DR, Pino K, et al. 2017. New locality records of Rhagomys longilingua Luna \& Patterson, 2003 (Rodentia: Cricetidae) in Peru. Check List 13(3): 1-7. https://doi.org/10.15560/13.3.2136

Medina CE, Gregorin R, Zeballos H, et al. 2014. A new species of Eumops (Chiroptera: Molossidae) from southwestern Peru. Zootaxa 3878(1): 19-36. https://doi. org/10.11646/zootaxa.3878.1.2

Medina CE, Lopez E, Pino K, et al. 2015. Biodiversidad de la zona reservada Sierra del Divisor (Perú): una visión desde los mamíferos pequeños. Revista Peruana de Biología 22(2): 199-212. https://doi.org/10.15381/ rpb.v22i2.11354

Medina CE, Medina YK, Pino K, et al. 2016a. Primer registro del ratón colombiano del bosque Chilomys instans (Cricetidae: Rodentia) en Cajamarca: actualizando el listado de mamíferos del Perú. Revista Peruana de Biología 23(3): 315-320. https://doi.org/10.15381/ rpb.v23i3.12868

Medina CE, Pari A, Delgado W, et al. 2012b. Primer registro de Eumops patagonicus y ampliación del rango de distribución geográfica de E. hansae (Chiroptera: Molossidae) en Perú. Mastozoología Neotropical 19(2): 345351.

Medina CE, Pino K, Pari A, et al. 2016b. Mammalian diversity in the savanna from Peru, with three new additions from the country. Papéis Avulsos de Zoologia 56(2): 9-26. https://doi.org/10.1590/0031-1049.2016.56.02

Medina CE, Zeballos H, López E. 2012a. Diversidad de mamíferos en los bosques montanos del valle de Kcosñipata, Cusco, Perú. Mastozoología Neotropical 19(1): 85104.

Mena JL, Hiyo-Bellido L. 2016. Outstanding record of the whitelipped peccary Tayassu pecari (Artiodactyla: Tayassuidae) in northern Andean montane forests of Peru. Suiform Soundings 14(2): 41-44.

Mena JL, Pacheco V. 2020. Mountains and traits: environmental heterogeneity and mammal assemblages along an elevational gradient in the northern Andes. Studies on Neotropical Fauna and Environment: 1-13. https:// doi.org/10.1080/01650521.2020.1851345

Mena JL, Velazco S, Arias E, Bernabé K. 2020. Bat occupancy based on mist-netting surveys in a montane landscape in northern Andes. Acta Chiropterologica 22(2): 327-336. $\quad$ https://doi.org/10.3161/15081109A CC2020.22.2.008

Mena JL, Williams M, Gazzolo C, Montero F. 2007. Estado de conservación de Melanomys zunigae (Sanborn 1949) y de los mamíferos pequeños en las Lomas de Lima. 
Revista Peruana de Biología 14(2): 201-208. https:// doi.org/10.15381/rpb.v14i2.1734

Mena JL, Williams M. 2002. Diversidad y patrones reproductivos de quirópteros en una área urbana de Lima, Perú. Ecología Aplicada 1(1-2): 1-8. https://doi. org/10.21704/rea.v1i1-2.222

Mena JL, Yagui H. 2019. Coexistence and habitat use of the South American coati and the mountain coati along an elevational gradient. Mammalian Biology 98: 119127. https://doi.org/10.1016/j.mambio.2019.09.004

Mena JL. 2010. Respuestas de los murciélagos a la fragmentación del bosque en Pozuzo, Perú. Revista Peruana de Biología 17(3): 277-84. https://doi.org/10.15381/ rpb.v17i3.2

Menajovsky MF, Pacheco V. 2017. Variación ontogénica y sexual de Oecomys bicolor (Rodentia, Cricetidae) de Perú y Ecuador. Revista Peruana de Biología 24(4): 383-390. https://doi.org/10.15381/rpb.v24i4.13918

Merino M, Galliari C, Pacheco V. 2009. Chapter: Mamíferos Grandes. Pp: 196-217. En: GE Soave, V Ferreti, G Mange, et al., eds. 2009. Diversidad biológica en la amazonía peruana: Programa de monitoreo de la biodiversidad en Camisea. Grupo Uroboros. 514 pp.

Michel-Vargas AM, Sejas-Lazarte WA., Linera-Canedo CDR, et al. 2019. Evaluación del uso de indicadores de biodiversidad en los estudios de evaluación de impacto ambiental (EEIAs) de los sectores más importantes de Bolivia. Acta Nova 9(2): 204-235.

MINAM (Ministerio del Ambiente). 2018. Situación actual de las especies de anfibios y reptiles del Perú. Ministerio del Ambiente, Dirección General de Diversidad Biológica. Lima.

Miranda FR, Casali DM, Perini FA, et al. 2017. Taxonomic review of the genus Cyclopes Gray, 1821 (Xenarthra: Pilosa), with the revalidation and description of new species. Zoological Journal of the Linnean Society 183(3): 1-35. https://doi.org/10.1093/zoolinnean/zlx079

Mittermeier RA, Robles P, Goettsch C, eds. 1997. Megadiversidad: Los países biológicamente más ricos del mundo. Cemex, Ciudad de México. 502 pp.

Mittermeier RA, Rylands AB, Wilson DE, eds. 2013. Handbook of the mammals of the world. Vol. 3. Primates. Lynx Edicions, Barcelona. 951 pp.

Molina-Veramendi M. 2019. Caracterización morfológica y molecular de una población de Akodon (Rodentia: Cricetidae) del norte de Perú. Tesis, Licenciado en Biología con mención en Zoología. Facultad de Ciencias Biológicas Universidad Nacional Mayor de San Marcos. <https://cybertesis.unmsm.edu.pe/handle/20.500.12672/10574>. Acceso 31/07/2021.

Moncayo A, Hice C, Watts DW, et al. 2001. Allpahuayo virus: a newly recognized arenavirus (Arenaviridae) from arboreal rice rats (Oecomys bicolor and Oecomys paricola) in northeastern Peru. Virology 284(2): 277-286. https://doi.org/10.1006/viro.2000.0803

Montenegro O, Moya L. 2011. Mamíferos. Pp. 126-133. En: N Pitman, C Vriesendorp, D Moskovits, et al., eds. Perú: Yaguas Cotuhé. Rapid Biological and Social Inventories Report 23. The Field Museum, Chicago, IL, USA. $154 \mathrm{pp}$.

Morales-Martínez DM, Ramírez-Chaves HE., Colmenares-Pinzón JE, Gómez LG. 2020. The Koepcke's spear-nosed bat, Gardnerycteris koepckeae (Gardner and Patton, 1972) (Chiroptera: Phyllostomidae), is not endemic to Peru: first record from the Amazon foothills of
Colombia. Mammalia 84(5): 439-447. https://doi. org/10.1515/mammalia-2019-0107

Moras LG, Gomes AM, Tavares VC. 2014. Distribution and taxonomy of the common Big-eared bat Micronycteris microtis (Chiroptera: Phyllostomidae) in South America. Mammalia 79(4): 439-447. https://doi.org/10.1515/ mammalia-2014-0057

Moras LM, Gregorin R, Sattler T, Tavares VC. 2018. Uncovering the diversity of Dog-faced bats of the genus Cynomops (Chiroptera: Molossidae), with the redescription of $\mathrm{C}$. milleri and the description of two new species. Mammalian Biology 89: 37-51. https://doi.org/10.1016/j. mambio.2017.12.005

Moras LM, Tavares VDC, Pepato AR, et al. 2016. Reassessment of the evolutionary relationships within the Dog-faced bats, genus Cynomops (Chiroptera: Molossidae). Zoologica Scripta 45(5): 465-480. https://doi. org/10.1111/zsc.12169

Moratelli R, Gardner AL, de Oliveira JA, Wilson DE. 2013. Review of Myotis (Chiroptera, Vespertilionidae) from northern South America, including description of a new species. American Museum Novitates 3780: 1-36. https://doi.org/10.1206/3780.2

Moratelli R, Novaes LM, Carrión-Bonilla C, Wilson DE. 2019. A new species of Myotis (Chiroptera, Vespertilionidae) from Peru. Pp. 239-256. En: RD Bradley, HH Genoways, DJ Schmidly y LC Bradley, eds. From field to laboratory: a memorial volume in honor of Robert J. Baker. Special Publications, Museum of Texas Tech University 71: xi + 1-911.

Moratelli R, Peracchi AL, Dias D, de Oliveira JA. 2011. Geographic variation in south American populations of Myotis nigricans (Schinz, 1821) (Chiroptera, Vespertilionidae), with the description of two new species. Mammalian Biology 76(5): 592-607. https://doi.org/10.1016/j. mambio.2011.01.003

Moratelli R, Wilson DE. 2011. A new species of Myotis Kaup, 1829 (Chiroptera, Vespertilionidae) from Ecuador. Mammalian Biology 76(5): 608-614. https://doi. org/10.1016/i.mambio.2010.10.003

More A, Crespo S. 2017. Registros documentados del puerco espín de cola corta Coendou rufescens (Erethizontidae, Rodentia) en el Noroeste de Perú. The Biologist 14(2): 350-369.

Moreira JR, Alvarez MR, Tarifa T, et al. 2013. Taxonomy, natural history and distribution of the capybara. Pp. 3-37. En: JR Moreira, KM Ferraz, EA Herrera y DW Macdonald, eds. Capybara Biology, Use and Conservation of an Exceptional Neotropical Species. Springer, New York, NY, USA. xvii + 419 pp. https://doi.org/10.1007/9781-4614-4000-0 1

Myers P, Patton JL. 2008. Genus Lestoros Oehser, 1934. Pp. 2426. En: Gardner AL, Ed. Mammals of South America, Volume 1: Marsupials, Xenarthrans, Shrews, and Bats. The University of Chicago Press, Chicago, IL, USA. xx +669 pp.

Nascimento FO, Cheng J, Feijó A. 2021. Taxonomic revision of the pampas cat Leopardus colocola complex (Carnivora: Felidae): an integrative approach. Zoological Journal of the Linnean Society 191(2): 575-611. https:// doi.org/10.1093/zoolinnean/zlaa043

Noblecilla MC, Pacheco. 2012. Dieta de roedores sigmodontinos (Cricetidae) en los bosques montanos tropicales de Huánuco, Perú. Revista Peruana de Biología 19(3): 317-322. https://doi.org/10.15381/rpb.v19i3.1046 
Novaes RLM, Garbino GS, Claudio VC, Moratelli R. 2018. Separation of monophyletic groups into distinct genera should consider phenotypic discontinuities: the case of Lasiurini (Chiroptera: Vespertilionidae). Zootaxa 4379(3): 439-440. https://doi.org/10.11646/zoota$\underline{\mathrm{xa} .4379 .3 .8}$

Novoa S, Cadenillas R, Pacheco V. 2011. Dispersión de semillas por murciélagos frugívoros en bosques del Parque Nacional Cerros de Amotape, Tumbes, Perú. Mastozoología Neotropical 18(1): 81-93.

Ochoa JA., Quispe R, Jara-Moscoso N, Cossios D. 2020. Confirmación de la presencia de la enigmática "rata chinchilla arborícola de Machupicchu" Cuscomys oblativus (Abrocomidae). Revista Peruana de Biología 27(2): 251-254. https://doi.org/10.15381/rpb.v27i2.17882

Ojala-Barbour 0, Pinto CM, Brito J, et al. 2013. A new species of shrew-opossum (Paucituberculata: Caenolestidae) with a phylogeny of extant caenolestids. Journal of Mammalogy 94(5): 967-982. https://doi. org/10.1644/13-MAMM-A-018.1

Ortega H et al. 2011. Lista anotada de los peces de aguas continentales del Perú: Estado actual del conocimiento, distribución, usos y aspectos de conservación. Ministerio del Ambiente, Dirección General de Diversidad Biológica - Museo de Historia Natural, UNMSM. 48 pp.

Ossa G, Zamora HT, Velazco PM. 2020. Platalina genovensium (Chiroptera: Phyllostomidae). Mammalian Species 52(995): 105-113. https://doi.org/10.1093/mspecies/seab001 https://doi.org/10.1093/mspecies/ seaa 008

Pacheco V, Arias L. 2001. Mammals. Pp. 155-158. En: LO Rodriguez y DK Moskovitz, eds. Perú: Biabo Cordillera Azul. Rapid Biological Inventories report 2. The Field $\mathrm{Mu}-$ seum, Chicago, IL, USA. 228 pp.

Pacheco V, Cadenillas R, Salas E, et al. 2009. Diversidad y endemismo de los mamíferos del Perú. Revista Peruana de Biología 16(1): 5-32. https://doi.org/10.15381/rpb. v16i1.111

Pacheco V, de Macedo H, Vivar E, et al. 1995. Lista anotada de los mamíferos peruanos. Occasional Papers in Conservation Biology 2: 1-35.

Pacheco V, Graham-Angeles L, Diaz S, et al. 2020a. Diversidad y distribución de los mamíferos del Perú por departamentos y ecorregiones I. Revista Peruana de Biología 27(3): 289-328. https://doi.org/10.15381/rpb. v27i3.18356

Pacheco V, Hocking P. 2006. Notably range extension of Sturnira aratathomasi Peterson and Tamsitt 1969 in Perú. Acta Chiropterologica 8(2): 561-566. https://doi.org/10.3161/17335329(2006)8[561:NREOSA]2.0.CO;2

Pacheco V, Inche B, Wust W. 2018b. Mamíferos del Perú. Grupo La República S.A., eds. Animales sorprendentes. Editorial Septiembre S.A.C., Lima. 120 pp.

Pacheco V, Márquez G, Salas E, et al. 2011. Diversidad de mamíferos en la cuenca media del río Tambopata, Puno, Perú. Revista Peruana de Biología 18(2): 231-244. https://doi.org/10.15381/rpb.v18i2.246

Pacheco V, Noblecilla M. 2019. Diversidad de mamíferos en el bosque montano de Carpish, Huánuco, Perú. Revista Peruana de Biología 26(2): 217-226. https://doi. org/10.15381/rpb.v26i2.16372

Pacheco V, Pacheco J, Zevallos A, et al. 2020b. Mamíferos pequeños de humedales de la costa central del Perú. Revista Peruana de Biología 27(4): 483-498. https://doi.

\section{org/10.15381/rpb.v27i4.19204}

Pacheco V, Peralta M. 2011. Rediscovery of Rhipidomys ochrogaster JA Allen, 1901 (Cricetidae: Sigmodontinae) with a redescription of the species. Zootaxa 3106: 4259. https://doi.org/10.11646/zootaxa.3106.1.3

Pacheco V, Rengifo E, Vivas D. 2014. Una nueva especie de ratón orejón del género Phyllotis Waterhouse, 1837 (Rodentia: Cricetidae) del norte del Perú. Therya 5(2): 481508. https://doi.org/10.12933/therya-14-185

Pacheco V, Salas E, Barriga C, Rengifo E. 2013. Diversidad de pequeños mamíferos en bosques montanos perturbados y no perturbados en el área de influencia del gasoducto de PERU LNG, cuenca del río Apurímac, Ayacucho, Perú. Pp. 305-316. En: A Alonso, F Dallmeier y G Servat, eds. Monitoreo de biodiversidad: Lecciones de un megaproyecto transandino. Smithsonian Institution Scholarly Press, Washington DC, USA. xxvii + 429 pp.

Pacheco V, Salas E, Cairampoma L, et al. 2007a. Contribución al conocimiento de la diversidad y conservación de los mamíferos en la cuenca del río Apurímac, Perú. Revista https://doi.org/10.15381/rpb.v14i2.1722

Pacheco V, Sánchez-Vendizú P, Solari S. 2018. A new species of Anoura Gray, 1838 (Chiroptera: Phyllostomidae) from Peru, with taxonomic and biogeographic comments on species of the Anoura caudifer complex. Acta Chiropterologica 20(1): 31-50. https://doi.org/10.3161/ 15081109ACC2018.20.1.002

Pacheco V, Ugarte-Núñez J. 2011. New records of Stolzmann's fish-eating rat Ichthyomys stolzmanni (Cricetidae, Sigmodontinae) in Peru: A rare species becoming a nuisance. Mammalian Biology - Zeitschrift Für Säugetierkunde 76(5): 657-661. https://doi.org/10.1016/j. mambio.2010.10.007

Pacheco V, Vivar E. 1996. Annotated checklist of the nonflying mammals at Pakitza, Manu Reserve Zone, Manu National Park, Perú. Pp. 577-591. En: DE Wilson y A Sandoval, eds. Manu, the biodiversity of southeastern Peru. Smithsonian Institution and Editorial Horizonte. Washington DC, USA. 679 pp.

Pacheco V, Zevallos A, Cervantes K, et al. 2015. Mamíferos del Refugio de Vida Silvestre Los Pantanos de Villa, LimaPerú. Científica 12(1): 26-41.

Pacheco V. 1991. A new species of Scolomys (Muridae: Sigmodontinae) from Peru. Publicaciones del Museo de Historia Natural, Universidad Nacional Mayor de San Marcos Serie A, Zoología 37: 1-3.

Pacheco V. 2002. Mamíferos del Perú. Pp. 503-550. En: G Ceballos y JA Simonetti, eds. Diversidad y conservación de los mamíferos neotropicales. Comisión Nacional para el Conocimiento y Uso de la Biodiversidad, Mexico DF, Mexico. $582 \mathrm{pp}$.

Pacheco V. 2015. Genus Thomasomys Coues, 1884. Pp. 617-882. En: JL Patton, UFJ Pardiñas y G D'Elía, eds. Mammals of South America, Volume 2: Rodents. The University of Chicago Press, Chicago, IL, USA. xxvi + 1336 pp.

Pacheco V. 2021. Range extension of Thomasomys princeps (Thomas, 1895) (Rodentia, Sigmodontinae) and first record in Venezuela. Check List 17(2): 385-393. https://doi.org/10.15560/17.2.385

Pacheco V, Cadenillas R, Velazco S, et al. 2007b. Noteworthy bat records from the Pacific tropical rainforest region and adjacent dry forest in northwestern Peru. Acta Chiropterologica $9(2): \quad 409-422$. https://doi.org/10.3161/17335329(2007)9[409:NBRFTP]2.0.CO;2 
Palma RE, Boric-Bargetto D, Jayat JP, et al. 2014. Molecular phylogenetics of mouse opossums: new findings on the phylogeny of Thylamys (Didelphimorphia, Didelphidae). Zoologica Scripta 43(3): 217-34. https://doi. org/10.1111/zsc.12051

Palmer RR, Koprowski JL. 2015. How do Neotropical pygmy squirrels (Sciurillus pusillus) use seasonally flooded forests in the Peruvian Amazon? Journal of Mammalogy 96(6): 1295-1304. https://doi.org/10.1093/ ¡mammal/gyv138

Pardiñas UFJ, Teta P, Alvarado-Serrano DF, et al. 2015. Genus Akodon Meyen, 1833. 2015. Pp. 144-203. En: JL Patton, UFJ Pardiñas y G D'Elía, eds. Mammals of South America, Volume 2: Rodents. The University of Chicago Press, Chicago, IL, USA. xxvi + 1336 pp.

Pari A, Pino K, Medina C, et al. 2015. Murciélagos de Arequipa, historia natural y conservación. Impresiones Juve E.I.R.L. Arequipa, Perú.

Parlos J, Timm RM, Swier VJ, et al. 2014. Evaluation of paraphyletic assemblages within Lonchophyllinae, with description of a new tribe and genus. Occasional Papers of the Museum of Texas Tech University 320: $1-23$.

Patiño-Guío MF. 2014. Análisis comparativo del componente fauna entre los términos de referencia para la elaboración de estudios de impacto ambiental en proyectos de explotación de hidrocarburos en Colombia y Perú. Tesis, Especialista en planeación ambiental y manejo integral de los recursos naturales, Universidad Militar Nueva Granada. Bogotá, Colombia. 22 pp.

Patterson BD, López-Wong C. 2014. Mamíferos/Mammals. Pp. 154-167, 344-356 and 504-517. En: N Pitman, C Vriesendorp, D Alvira, et al., eds. Perú: Cordillera EscaleraLoreto. Rapid Biological and Social Inventories Report 26. The Field Museum, Chicago, IL, USA. 541 pp.

Patterson BD, Ramírez-Chaves HE, Vilela JF, et al. 2021. On the nomenclature of the american clade of weasels (Carnivora: Mustelidae). Journal of Animal Diversity 3(2): 1-8. https://dx.doi.org/10.52547/JAD.2021.3.2.1

Patterson BD, Smith MF, Teta P. Genus Abrothrix Waterhouse, 1837. 2015. Pp. 109-127. En: JL Patton, UFJ Pardiñas y G D'Elía, eds. Mammals of South America, Volume 2: Rodents. The University of Chicago Press, Chicago, IL, USA. xxvi + $1336 \mathrm{pp}$.

Patterson BD, Velazco P. 2006. A distinctive new cloud-forest rodent (Hystriocognathi: Echimyidae) from the Manu Biosphere Reserve, Peru. Mastozoología Neotropical 13(2): 175-191.

Patton J.L. 2015. Genus Punomys Osgood, 1943. Pp. 103-105. En: JL Patton, UFJ Pardiñas y G D'Elía, eds. Mammals of South America, Volume 2: Rodents. The University of Chicago Press, Chicago, IL, USA. xxvi + 1336 pp.

Patton JL, da Silva MN, Malcolm JR. 2000. Mammals of the Rio Juruá and the evolutionary and ecological diversification of Amazonia. Bulletin of the American Museum of Natural History 244: 1-306. https://doi. org/10.1206/0003-0090(2000)244<0001:MOTRJA $>$ 2.0.CO;2

Patton JL, Emmons LH. 2015. Family Dasyproctidae Bonaparte, 1838. Pp. 733-762. En: JL Patton, UFJ Pardiñas y G D'Elía, eds. Mammals of South America, Volume 2: Rodents. The University of Chicago Press, Chicago, IL, USA. xxvi + 1336 pp.

Patton JL, Leite RN. 2015. Genus Proechimys J. A. Allen, 1899. Pp. 950-989. En: En: JL Patton, UFJ Pardiñas y G D'Elía, eds. Mammals of South America, Volume 2: Rodents. The University of Chicago Press, Chicago, IL, USA. xxvi $+1336 \mathrm{pp}$.

Patton JL, Pardiñas UFJ, D'Elía G, eds. Mammals of South America, Volume 2: Rodents. The University of Chicago Press, Chicago, IL, USA. xxvi + 1336 pp.

Patton JL. 2015. Genus Lenoxus Thomas, 1909. Pp: 231-232. En: JL Patton, UFJ Pardiñas y G D'Elía, eds. Mammals of South America, Volume 2: Rodents. The University of Chicago Press, Chicago, IL, USA. xxvi + 1336 pp.

Pavan AC, Cadenillas R, Centty O, et al. 2021. On the taxonomic identity of Pteronotus davyi incae Smith, 1972 (Chiroptera: Mormoopidae). American Museum Novitates 3966: 1-23. https://doi.org/10.1206/3966.1

Pavan AC, Marroig G. 2016. Integrating multiple evidences in taxonomy: species diversity and phylogeny of Mustached bats (Mormoopidae: Pteronotus). Molecular Phylogenetics Evolution 103: 1010-1026. https://doi. org/10.1016/i.ympev.2016.07.011

Pavan AC, Martins F, Morgante J. 2013. Evolutionary history of Bulldog bats (genus Noctilio): recent diversification and the role of the Caribbean in Neotropical biogeography. Biological Journal 108: 201-224. https://doi. org/10.1111/j.1095-8312.2012.01979.x

Pavan SE, Voss RS. 2016. A revised subgeneric classification of Short-tailed opossums (Didelphidae: Monodelphis). American Museum Novitates 3868: 1-44. https://doi. org/10.1206/3868.1

Pavan SE. 2019. A revision of the Monodelphis glirina group (Didelphidae: Marmosini), with a description of a new species from Roraima, Brazil. Journal of Mammalogy 100(1): 103-117. https://doi.org/10.1093/jmammal/gyy 165

Pearson OP. 1957. Additions to the mammalian fauna of Peru and notes on some other Peruvian mammals. Brevoria 73: 1-7.

Peralta M, Pacheco V. 2014. Rediscovery of Marmosops juninensis Tate, 1931 (Didelphimorphia: Didelphidae) in the Yungas of Peru. Check List 10(2): 436-440. https://doi.org/10.15560/10.2.436

Percequillo AR. 2015a. Genus Cerradomys Weksler, Percequillo, and Voss, 2006. Pp. 300-308. En: JL Patton, UFJ Pardiñas y G D'Elía, eds. Mammals of South America, Volume 2: Rodents. The University of Chicago Press, Chicago, IL, USA. xxvi + 1336 pp.

Percequillo AR. 2015b. Genus Eremoryzomys Weksler, Percequillo, and Voss, 2006. Pp. 310-312. En: JL Patton, UFJ Pardiñas y G D'Elía, eds. Mammals of South America, Volume 2: Rodents. The University of Chicago Press, Chicago, IL, USA. xxvi + 1336 pp.

Percequillo AR. 2015c. Genus Nephelomys Weksler, Percequillo, and Voss, 2006. Pp. 377-390. En: JL Patton, UFJ Pardiñas y G D'Elía, eds. Mammals of South America, Volume 2: Rodents. The University of Chicago Press, Chicago, IL, USA. xxvi + 1336 pp.

Perez-Peña P, Riveros MS, Mayor P, et al. 2017. Estado poblacional del sajino Pecari tajacu y huangana Tayassu pecari en la Amazonía peruana. Folia Amazónica 26(2): 103120. https://doi.org/10.24841/fa.v26i2.429

Pinto CM, Marchán-Rivadeneira MR, Tapia EE, et al. 2013. Distribution, abundance and roosts of the fruit bat Artibeus fraterculus (Chiroptera: Phyllostomidae). Acta Chiropterologica 15(1): 85-94. https://doi. org/10.3161/150811013X667885 
Portugal-Zegarra G, Flores-Quispe M, Calizaya-Mamani G, Aragón G. 2020. New record of Nyctinomops aurispinosus with an update of its known distribution. Therya Notes 1(1): 67-76. https://doi.org/10.12933/therya notes-20-16

Prado JR, Knowles LL, Percequillo AR. 2021. New species boundaries and the diversification history of Marsh rat taxa clarify historical connections among ecologically and geographically distinct wetlands of South America. Molecular Phylogenetics and Evolution 155: 106992. https://doi.org/10.1016/j.ympev.2020.106992

Prado JR, Percequillo A. 2018. Systematic studies of the genus Aegialomys Weksler et al., 2006 (Rodentia: Cricetidae: Sigmodontinae): Geographic variation, species delimitation, and biogeography. Journal of Mammalian Evolution 25: 71-118. https://doi.org/10.1007/s10914016-9360-y

Prieto-Torres DA, Pinilla-Buitrago G. 2017. Estimating the potential distribution and conservation priorities of Chironectes minimus (Zimmermann, 1780) (Didelphimorphia: Didelphidae). Therya 8(2): 131-144. https://doi.org/10.12933/therya-17-478

Puertas PE, Aquino R, Encarnación F. 2006. Uso de alimentos y competición entre el mono nocturno Aotus vociferans y otros mamíferos, Loreto, Perú. Folia Amazónica 4(2): 151-160. https://doi.org/10.24841/fa.v4i2.213

Quintana H, Pacheco V, Salas E. 2009. Diversidad y conservación de los mamíferos de Ucayali, Perú. Ecología Aplicada 8(1-2): 91-103. https://doi.org/10.21704/rea. v8i1-2.386

Quintana H, Pacheco V. 2007. Identificación y distribución de los murciélagos vampiros del Perú. Revista Peruana de Medicina Experimental y Salud Pública 24(1): 8188.

Quintela FM, da Rosa C, Feijó A. 2020. Updated and annotated checklist of recent mammals from Brazil. Anais da Academia Brasileira de Ciências 92 (Suppl. 2): e20191004. https://doi.org/10.1590/0001-3765202020191004

Ramirez 0, Arana M, Bazán E, et al. 2007. Assemblages of bird and mammal communities in two major ecological units of the Andean highland plateau of southern Peru. Ecologia Aplicada 6(1-2): 139-148. https://doi. org/10.21704/rea.v6i1-2.350

Ramírez-Chaves HE, Mulder KP, Marín D, et al. 2012. Has Colombian weasel Mustela felipei been overlooked in collections? Small Carnivore Conservation 47: 30-34.

Ramírez-Chaves HE, Suárez-Castro AF, Morales-Martínez DM, et al. 2021. Mamíferos de Colombia. v1.12. Sociedad Colombiana de Mastozoología. Dataset/Checklist. https://dx.doi.org/10.15472/kl1whs

Ramos-Rodríguez MC, Cevillano S. 2019. Notas sobre la dieta de murciélagos frugívoros en el bosque de colina, Loreto, Perú. Ciencia Amazónica 7(1): 79-92. https:// doi.org/10.22386/ca.v7i1.266

Ramos-Rodríguez MC, Cevillano SC, Aquino R, et al. 2017. Diversidad de murciélagos en bosques de colina del río Itaya, Loreto, Perú. Folia Amazónica 26(2): 139-152. https://doi.org/10.24841/fa.v26i2.430

Regalado J, Albuja L. 2012. Ampliación de la distribución de Sturnira nana y Lophostoma brasiliense en el Ecuador. Revista Politécnica 30(3): 160-165.

Rengifo E, Pacheco V, Salas E. 2011. An additional record of Platyrrhinus ismaeli Velazco, 2005 on the western slope of Peru, with taxonomic comments. Chiroptera Neotropical 17(1): 803-807.
Rengifo E, Pacheco V. 2015. Taxonomic revision of the Andean leaf-eared mouse, Phyllotis andium Thomas 1912 (Rodentia: Cricetidae), with the description of a new species. Zootaxa 4018(3): 349-380. https://doi. org/10.11646/zootaxa.4018.3.2

Rengifo EM, Linares V, Díaz F, Panaifo J. 2014. First record of albinism in the Black mastiff bat Molossus rufus E. Geoffroy, 1805. Chiroptera Neotropical 20(2): 12881291.

RP N 106-2020-SERNANP. 2021. Resolución Presidencial que aprueba el Plan de Acción para la promoción de investigaciones en el SINANPE del periodo 2020-2022, SERNANP. 10 de julio del 2020.6 pp.

Reyes JC. 2009. Ballenas, delfines y otros cetáceos del Perú, una fuente de información. Squema-Ediciones, Lima, Perú. $159 \mathrm{pp}$.

Rivera PC, González-Ittig RE, Robainas-Barcia A, et al. 2018. Molecular phylogenetics and environmental niche modeling reveal a cryptic species in the Oligoryzomys flavescens complex (Rodentia, Cricetidae). Journal of Mammalogy 99: 363-376. https://doi.org/10.1093/ ¡mammal/gyx186

Rodríguez JJ, Amanzo JM. 2001. Chapter 9: Medium and large mammals of the southern Vilcabamba region, Peru. Pp. 117-126. En: A Alonso, T Schulenberg y F Dallmeier, eds. Biological and social assessments of the Cordillera de Vilcabamba, Peru. RAP Working Papers 12 and SI/MAB Series 6. Conservation International, Washington DC, USA. 296 pp.

Rodríguez JJ. 1998. Mamíferos de la Zona Reservada de Tumbes. Pp. 67-77. En: W Wust, ed. La Zona Reservada de Tumbes- Biodiversidad y diagnóstico socioeconómico. Fondo Nacional por las Áreas Protegidas por el Estado (PROFONANPE), Lima, Perú. 188 pp.

Rodríguez-Herrera B, Ramírez-Fernández JD, Villalobos-Chaves D, Sánchez R. 2014. Actualización de la lista de especies de mamíferos vivientes de Costa Rica. Mastozoología Neotropical 21(2): 275-289.

Rodríguez-Posada ME, Morales-Martínez DM, Ramírez-Chaves HE, et al. 2021. A new species of Long-eared brown bat of the genus Histiotus (Chiroptera) and the revalidation of Histiotus colombiae. Caldasia 43(2): 221-234. https://doi.org/10.15446/caldasia.v43n2.85424

Rossi RV, Bodmer R, Duarte JM, et al. 2010a. Amazonian brown brocket deer Mazama nemorivaga (Cuvier 1817). Pp. 202-210. En: JMB Duarte y S González, eds. Neotropical Cervidology: Biology and Medicine of Latin American Deer. FUNEP-IUCN. 393 pp.

Rossi RV, Voss RS, Lunde DP. 2010b. A revision of the didelphid marsupial genus Marmosa, Part 1: The species in Tate's "Mexicana" and "Mitis" sections and other closely related forms. Bulletin of the American Museum of Natural History 334: 1-83. https://doi. org/10.1206/334.1

Rowe N, Jacobs R. 2016. Tamarins and marmosets. Pp. 329-387. En: N Rowe y M Myers, eds. All the World's Primates. Pogonias Press, Charlestown, USA. xxi + 777 pp.

Ruedas LA, Silva SM, French JH, et al. 2017. A prolegomenon to the systematics of south American cottontail rabbits (Mammalia, Lagomorpha, Leporidae: Sylvilagus): Designation of a neotype for S. brasiliensis (Linnaeus, 1758), and restoration of S. andinus (Thomas, 1897) and S. tapetillus Thomas, 1913. Miscellaneous Publications, Museum of Zoology, University of Michigan 205: 1-67. http://hdl.handle.net/2027.42/136089 
Ruedas LA. 2017. A new species of cottontail rabbit (Lagomorpha: Leporidae: Sylvilagus) from Suriname, with comments on the taxonomy of allied taxa from northern south America. Journal of Mammalogy 98(4): 1042-1059. https://doi.org/10.1093/imammal/ gyx 048

Ruelas D, Bardales R, Molina M, et al. 2016a. Capítulo 9: Diversidad y abundancia de mamíferos pequeños no voladores en la concesión de conservación río La Novia y comentarios sobre su distribución. Pp. 129-147. En: JL Mena y C Germaná, eds. Diversidad biológica del sudeste de la Amazonía peruana: avances en la investigación. Consorcio Purús-Manu: WWF, CARE Perú, ProNaturaleza, ProPurús, Sociedad Zoológica de Fráncfort, ORAU, Lima, Perú. 308 pp.

Ruelas D, López E. 2018. Análisis morfogeométrico de las especies peruanas de Carollia (Chiroptera: Phyllostomidae). Mastozoología Neotropical 25(2): 419-438. https://doi.org/10.31687/saremMN.18.25.2.0.03

Ruelas D, Pacheco V, Espinoza N, Loaiza C. 2018. Bat diversity from the río La Novia Conservation Concession, Ucayali, Peru. Revista Peruana de Biología 25(3): 211220. https://doi.org/10.15381/rpb.v25i3.14091

Ruelas D, Pacheco V, Inche B, Tinoco N. 2021. A preliminary review of Nephelomys albigularis (Tomes, 1860) (Rodentia: Cricetidae), with the description of a new species from the Peruvian montane forests. Zootaxa 5027(2): 175-210. https://doi.org/10.11646/zoota$\underline{\mathrm{xa} .5027 .2 .3}$

Ruelas D, Pacheco V, Jiménez CF. 2020. Range extension and phylogenetic relationships of Akodon josemariarguedasi (Rodentia: Cricetidae) with comments on the aerosus species group. Mammalia 84(2): 207-213. https://doi.org/10.1515/mammalia-2018-0209

Ruelas D, Pacheco V. 2015b. Taxonomía y distribución de Vampyriscus brocki (Peterson 1968; Phyllostomidae: Chiroptera) en Perú y primer registro para Ucayali. Therya 6(3): 625-642. https://doi.org/10.12933/ therya-15-302

Ruelas D, Pacheco V. 2021a. Small mammals from the seasonally dry tropical forests of the Huallaga river basin and new records for San Martín department, Peru. Check List 17(3): 877-894. https://doi.org/10.15560/17.3.877

Ruelas D, Pacheco V. 2021b. Taxonomic status and phylogenetic position of Oxymycterus juliacae Allen 1900 (Rodentia: Cricetidae). Mammalia 2021: 1-19. https://doi. org/10.1515/mammalia-2021-0028

Ruelas D, Pacheco V. 2021c. A new species of Thomasomys Coues, 1884 (Rodentia: Sigmodontinae) from the montane forests of northern Peru with comments on the "aureus" group. Revista Peruana de Biología 28(3): e19912-e19912. https://doi.org/10.15381/ rpb.v28i3.19912

Ruelas D, Pardiñas UFJ. 2017. Hairy-tailed Akodont Necromys lasiurus. Pp. 469. En: DE Wilson, TE Jr. Lacher y RA Mittermeier, eds. Handbook of the Mammals of the World. Vol. 7. Rodents II. Lynx Edicions, Barcelona. $1008 \mathrm{pp}$.

Ruelas D, Soria C. 2021. First records of the bats Eumops bonariensis (Chiroptera: Molossidae) and Pteronotus fuscus (Chiroptera: Mormoopidae) in Peru. Mammalia 85(6): 1-13. https://doi.org/10.1515/mammalia-2020-0121

Ruelas D, Taco M, Ruelas C, et al. 2016b. Capítulo 10: Diversidad de mamíferos medianos y grandes de la cuenca del río La Novia, Purús. Pp. 148-171. En: JL Mena y C
Germaná, eds. Diversidad biológica del sudeste de la Amazonía peruana: avances en la investigación. Consorcio Purús-Manu: WWF, CARE Perú, ProNaturaleza, ProPurús, Sociedad Zoológica de Fráncfort, ORAU, Lima, Perú. 308 pp.

Ruelas D. 2017. Diferenciación morfológica de Carollia brevicauda y C. perspicillata (Chiroptera: Phyllostomidae) de Perú y Ecuador. Revista Peruana de Biología 24(4): 363-382. https://doi.org/10.15381/rpb.v24i4.14063

Ruelas D. 2019. Variación ontogenética y dimorfismo sexual en Platalina genovensium (Chiroptera: Phyllostomidae). Revista Peruana de Biología 26(2): 201-209. https:// doi.org/10.15381/rpb.v26i2.15337

Ruíz-García M, Cossíos D, Lucherini M, et al. 2013. Chapter 7: Population genetics and spatial structure in two Andean cats (the Pampas cat, Leopardus pajeros and the Andean mountain cat, L. jacobita) by means of nuclear and mitochondrial markers and some notes on skull biometrics. Pp. 187-244. En: M Ruíz-García y JM Shostell, eds. Molecular Population Genetics, Phylogenetics, Evolutionary Biology and Conservation of the Neotropical Carnivores. Hauppauge. Nova Science Publishers, NY, USA. 739 pp.

Ruiz-García M, Pinedo-Castro M, Shostell JM. 2014. How many genera and species of Woolly monkeys (Atelidae, Platyrrhine, Primates) are there? The first molecular analysis of Lagothrix flavicauda, an endemic Peruvian primate species. Molecular Phylogenetics and Evolution 79: 179-198. https://doi.org/10.1016/i.ympev.2014.05.034

Ruiz-García M, Pinilla-Beltrán D, Murillo-García OE. et al. 2021. Comparative mitogenome phylogeography of two anteater genera (Tamandua and Myrmecophaga; Myrmecophagidae, Xenarthra): Evidence of discrepant evolutionary traits. Zoological Research 42(5): 525-547. $\quad$ https://doi.org/10.24272/i.issn.2095$\underline{8137.2020 .365}$

Rumiz DI, Pardo E, Eulert CF, et al. 2007. New records and a status assessment of a rare Dwarf brocket deer from the montane forests of Bolivia. Journal of Zoology 271(4): 428-436. https://doi.org/10.1111/j.14697998.2006.00226.x

Rumiz DI, Pardo E. 2010. Peruvian Dwarf brocket deer Mazama chunyi (Hershkovitz 1959). Pp.185-189. En: MB Duarte y S Gonzales, eds. Neotropical Cervidology: Biology and medicine of Latin American deer. Jaboticabal, Brazil: Funep and Gland, Switzerland: IUCN. 393 pp.

Sahley CT, Cervantes K, Pacheco V, et al. 2015. Diet of a sigmodontine rodent assemblage in a Peruvian montane forest. Journal of Mammalogy 96(5): 1-10. https://doi. org/10.1093/imammal/gyv112

Salazar-Bravo J, Jayat JP. 2015. Genus Andinomys Thomas, 1902. Pp. 75-77. En: JL Patton, UFJ Pardiñas, G D'Elía, eds. Mammals of South America, Volume 2: Rodents. The University of Chicago Press, Chicago, IL, USA. xxvi + 1336 pp.

Salazar-Bravo J, Pardiñas UFJ, Zeballos H, Teta P. 2016. Description of a new tribe of sigmodontine rodents (Cricetidae: Sigmodontinae) with an updated summary of valid tribes and their generic contents. Occasional Papers of the Museum of Texas Tech University 338: $1-23$.

Salazar-Bravo J. 2015a. Genus Chinchillula Thomas, 1898. Pp. 78-79. En: JL Patton, UFJ Pardiñas, G D'Elía, eds. Mammals of South America, Volume 2: Rodents. The University of Chicago Press, Chicago, IL, USA. xxvi + 1336 pp. 
Salazar-Bravo J. 2015b. Genus Auliscomys Osgood, 1915. Pp. 472-479. En: JL Patton, UFJ Pardiñas, G D'Elía, eds. Mammals of South America, Volume 2: Rodents. The University of Chicago Press, Chicago, IL, USA. xxvi + $1336 \mathrm{pp}$.

Sánchez A, Vásquez P. 2007. Presión de caza de la comunidad nativa Mushuckllacta de Chipaota, zona de amortiguamiento del Parque Nacional Cordillera Azul, Perú. Ecología Aplicada 6(1-2): 131-138. https://doi. org/10.21704/rea.v6i1-2.349

Sánchez HJ, Lew D. 2012. Lista actualizada y comentada de los mamíferos de Venezuela. Memoria de la Fundación La Salle de Ciencias Naturales 173(174): 173-238.

Sánchez P, Pacheco V. 2016. New record of Sturnira bakeri Velazco \& Patterson, 2014 (Chiroptera: Phyllostomidae) from northwestern Peru. Check List 12(5): 1-7. https://doi.org/10.15560/12.5.1984

Sánchez-Cordero V, Botello F, Flores-Martínez JJ, et al. 2014. Biodiversity of Chordata (Mammalia) in Mexico. Revista Mexicana de Biodiversidad 85: S496-S504. https://doi.org/10.7550/rmb.31688

Sánchez-Vendizú P, Pacheco V, Vivas-Ruiz D. 2018. An introduction to the systematics of small-bodied Neacomys (Rodentia: Cricetidae) from Peru with descriptions of two new species. American Museum Novitates 3913: 1-38. https://doi.org/10.1206/3913.1

Satizábal P, Mignucci-Giannoni AA, Duchêne S, et al. 2012. Phylogeography and sex-biased dispersal across riverine manatee populations (Trichechus inunguis and Trichechus manatus) in South America. PLoS one 7(12): e52468. https://doi.org/10.1371/journal. pone.0052468

Semedo TBF, da Silva MNF, Carmignotto AP, Rossi RV. 2021. Three new species of spiny mice, genus Neacomys Thomas, 1900 (Rodentia: Cricetidae), from Brazilian Amazonia. Systematics and Biodiversity 0(0): 1-22. https://doi.org/10.1080/14772000.2021.1980449

Serrano-Villavicencio JE, Bartoletti T, Bueno C. 2020. Mammals collected by Johann Jakob von Tschudi in Peru during 1838-1842 for the Muséum d'Histoire Naturelle de Neuchâtel, Switzerland. Boletim do Museu Paraense Emílio Goeldi-Ciências Naturais 15(3): 905-931. https://doi.org/10.46357/bcnaturais.v15i3.249

Serrano-Villavicencio JE, Hurtado CM, Vendramel RL, Nascimento FOD. 2019. Reconsidering the taxonomy of the Pithecia irrorata species group (Primates: Pitheciidae). Journal of Mammalogy 100(1): 130-141. https:// doi.org/10.1093/jmammal/gyy167

Shanee S, Shanee N, Allgas-Marchena N. 2013. Primate surveys in the Marañon-Huallaga Landscape, northern Peru with notes on conservation. Primate Conservation 27: 3-11. https://doi.org/10.1896/052.027.0114

Shanee S, Shanee N. 2018. Diversity of large mammals in the Marañón-Huallaga landscape, Peru: with notes on rare species. Zoology and Ecology 28(4): 313-328. https:// doi.org/10.1080/21658005.2018.1516277

Silva LGDL, Ferreira DC, Rossi RV. 2019. Species diversity of Marmosa subgenus Micoureus (Didelphimorphia, Didelphidae) and taxonomic evaluation of the Whitebellied woolly mouse opossum, Marmosa constantiae. Zoological Journal of the Linnean Society 187(1): 240277. https://doi.org/10.1093/zoolinnean/zlz023

Simmons NB, Voss RS, Fleck DW. 2002. A new Amazonian species of Micronycteris (Chiroptera: Phyllostomidae) with notes on the roosting behavior of sympatric congeners.
American Museum Novitates 3358: 1-16. https://doi. org/10.1206/0003-0082(2002)358<0001:ANASOM> 2.0.CO;2

Solari S, Hoofer SR, Larsen PA, et al. 2009. Operational criteria for genetically defined species: analysis of the diversification of the Small fruit-eating bats, Dermanura (Phyllostomidae: Stenodermatinae). Acta Chiropterologica 11(2): 279-288. https://doi. org/10.3161/150811009X485521

Solari S, Pacheco V, Luna L, et al. 2006. Mammals of the Manu Biosphere Reserve. En: BD Patterson, DF Stotz y S Solari, eds. Mammals and birds of the Manu Biosphere Reserve, Peru. Fieldiana Zoology (New Series) 110: 13-22. https://doi.org/10.3158/00150754(2006)110[1:MABOTM]2.0.CO;2

Solari S, Pacheco V, Vivar E. 1999. New distribution records of Peruvian bats. Revista Peruana de Biología 6(2): 152159. https://doi.org/10.15381/rpb.v6i2.8310

Solari S, van Den Bussche RA, Hoofer SR, Patterson BD. 2004. Geographic distribution, ecology, and phylogenetic affinities of Thyroptera lavali Pine 1993. Acta Chiropterologica 6(2): 293-302. https://doi. org/10.3161/001.006.0207

Solari S, Vivar E, Velazco P, Rodríguez JJ. 2001. Chapter 8: Small mammals of the southern Vilcabamba region, Peru. Pp. 110-116. En: LE Alonso, A Alonso, TS Schulenberg y F Dallmeier, eds. Biological and social assessments of the Cordillera de Vilcabamba, Peru. RAP Working Papers 12 and SI/MAB Series 6. Conservation International, Washington DC, USA. 296 pp.

Solari S. 2004. A new species of Monodelphis (Didelphimorphia: Didelphidae) from southeastern Peru. Mammalian Biology 69(3): 145-152.https://doi. org/10.1078/1616-5047-00129

Solari S. 2007. New species of Monodelphis (Didelphimorphia: Didelphidae) from Peru, with notes on M. adusta. Journal of Mammalogy 88(2): 319-329. https://doi. org/10.1644/06-MAMM-A-075R1.1

Spotorno A, Patton J. 2015. Superfamily Chinchilloidea Bennett, 1833. Pp. 781-783. En: JL Patton, UFJ Pardiñas, G D'Elía, eds. Mammals of South America, Volume 2: Rodents. The University of Chicago Press, Chicago, IL, USA. xxvi + 1336 pp.

Steppan SJ, Ramirez 0, Banbury J, et al. 2007. A molecular reappraisal of the systematics of the Leaf-eared mice Phyllotis and their relatives. Pp.799-826. En: DA Kelt, EP Lessa, J Salazar-Bravo y JL Patton, eds. The Quintessential Naturalist honoring the life and legacy of Oliver P. Pearson. University of California Publications in Zoology 134: 1-975. https://doi.org/10.1525/california/9780520098596.003.0023

Steppan SJ, Ramirez O. 2015. Genus Phyllotis Water house, 1837. Pp. 535-555. En: JL Patton, UFJ Pardiñas, G D'Elía, eds. Mammals of South America, Volume 2: Rodents. The University of Chicago Press, IL, USA. xxvi + 1336 pp.

Tavares VD, Gardner AL, Ramírez-Chaves HE, Velazco PM. 2014. Systematics of Vampyressa melissa Thomas, 1926 (Chiroptera: Phyllostomidae), with descriptions of two new species of Vampyressa. American Museum Novitates 3813: 1-27. https://doi.org/10.1206/3813.1

Tejedor A. 2003. First record of Saccopteryx canescens (Chiroptera: Emballonuridae) for southeastern Peru. Chiroptera Neotropical 9(1-2): 162-164.

Tello C, Streicker DG, Gomez J, Velazco PM. 2013. New records of pigmentation disorders in molossid and phyllosto- 
mid (Chiroptera) bats from Peru. Mammalia 78(2): 1-7. https://doi.org/10.1515/mammalia-2013-0019

Teta P, Abba AM, Cassini GH, et al. 2018. Lista revisada de los mamíferos de Argentina. Mastozoología Neotropical 25(1): 163-198. https://doi.org/10.31687/saremMN.18.25.1.0.15

Tirira DG, Brito J, Burneo SF y Comisión de Diversidad de la AEM. 2020. Mamíferos del Ecuador: lista actualizada de especies / Mammals of Ecuador: Updated checklist species. Versión 2020.2. Asociación Ecuatoriana de Mastozoología. Quito. «http://aem.mamiferosdelecuador.com> [actualización / updated: 2020-12-11].

Toffoli R, Boano G, Bonardi A, et al. 2018. Contribution to the bats knowledge of the Pacaya Samiria National Reserve, Loreto, Peru (Mammalia Chiroptera). Biodiversity Journal 29(4): 351-356. https://doi.org/10.31396/ Biodiv.Jour.2018.9.4.351.356

Torres-Oyarce L, Bardales-Alvites C, Tirado-Herrera E, et al. 2017. Estado de las poblaciones de mamíferos en la Reserva Nacional Matsés, al noreste de la Amazonía peruana. Folia Amazónica 26(2): 1-8. https://doi. org/10.24841/fa.v26i2.428

Tovar SA. 1971. Catálogo de mamíferos peruanos. Anales Científico UNA (Lima) 9: 18-37.

Tovar-Narváez A, Tovar-Ingar C, Saito-Díaz J, et al. 2010. Yungas Peruanas - Bosques montanos de la vertiente oriental de los Andes del Perú: Una perspectiva ecorregional de conservación. Universidad Nacional Agraria La Molina - Centro de Datos para la Conservación. Punto Impreso S.A. Lima, Perú. 139 pp.

Tribe CJ. 2015. Genus Rhipidomys Tschudi, 1845. Pp. 583-617. En: JL Patton, UFJ Pardiñas, G D'Elía, eds. Mammals of South America, Volume 2: Rodents. The University of Chicago Press, Chicago, IL, USA. xxvi + 1336 pp.

Trolle M, Emmons LH. 2004. A record of a Dwarf brocket from lowland Madre de Dios, Peru. Deer News 19: 2-5. https://repository.si.edu/handle/10088/4762

Tschudi JJ. 1844. Mammalium conspectus quae in Republica Peruana reperiuntur et pleraque observata vel collecta sunt in itinerere. Archiv für Naturgeschichte 10: 244-255.

Uturunco A, Pacheco V. 2016. Redescripción de Eremoryzomys polius (Rodentia: Cricetidae) y descripción de una nueva especie del género Eremoryzomys. Mastozoología Neotropical 23(2): 483-503.

Vargas-Linares E, Romaní-Romaní F, López-Ingunza R, et al. 2014. Rabia en Potos flavus identificados en el departamento de Madre de Dios, Perú. Revista Peruana de Medicina Experimental y Salud Publica 31(1): 88-93. https://doi.org/10.17843/rpmesp.2014.311.13

Vásquez-Újina FA. 2019. Murciélagos indicadores de perturbación del área de concesión para la conservación en la cuenca alta del río Itaya y zonas aledañas perturbadas, Loreto-Perú. Tesis, Licenciado en Ingeniería Ambiental. Facultad de Ciencias e Ingeniería Universidad Científica del Perú. Acceso 16/06/2021. <http:// repositorio.ucp.edu.pe/bitstream/handle/UCP/957/ FLORENA_VASQUEZ_ING.AMB_TESIS_TITULO_2019. pdf? sequence $=1 \&$ isAllowed $=y>$.

Velazco PM, Almeida FC, Cláudio VC, et al. 2021b. A new species of Histiotus Gervais, 1856 (Chiroptera, Vespertilionidae), from the Pacific Coast of Northern Peru. American Museum Novitates 3979: 1-30. https://doi. org/10.1206/3979.1

Velazco PM, Cadenillas R, Centty O, et al. 2013. New records of
Platalina genovensium (Chiroptera, Phyllostomidae) and Tomopeas ravus (Chiroptera, Molossidae). Mastozoología Neotropical 20(2): 425-434.

Velazco PM, Cadenillas R. 2011. On the identity of Lophostoma silvicolum occidentalis (Davis \& Carter, 1978) (Chiroptera: Phyllostomidae). Zootaxa 2962: 1-20. https://doi.org/10.11646/zootaxa.2962.1.1

Velazco PM, Gardner AL. 2009. A new species of Platyrrhinus (Chiroptera: Phyllostomidae) from western Colombia and Ecuador, with emended diagnoses of P. aquilus, P. dorsalis, and P. umbratus. Proceedings of the Biological Society of Washington 122(3): 249-281. https:// doi.org/10.2988/08-40.1

Velazco PM, Gardner AL. 2012. A new species of Lophostoma d'Orbigny, 1836 (Chiroptera: Phyllostomidae) from Panama. Journal of Mammalogy 93(2): 605-614. https://doi.org/10.1644/11-MAMM-A-217.1

Velazco PM, Gardner, Patterson BD. 2010. Systematics of the Platyrrhinus helleri species complex (Chiroptera: Phyllostomidae), with descriptions of two new species. Zoological Journal of the Linnean Society 159: 785-812. $\quad$ https://doi.org/10.1111/j.1096$\underline{3642.2009 .00610 . x}$

Velazco PM, Gregorin R, Voss RS, Simmons NB. 2014. Extraordinary local diversity of Disk-Winged bats (Thyropteridae: Thyroptera) in northeastern Peru, with the description of a new species and comments on roosting behavior. American Museum Novitates 3795: 1-28. https://doi.org/10.1206/3795.1

Velazco PM, Guevara L, Molinari J. 2018. Systematics of the broad-nosed bats, Platyrrhinus umbratus (Lyon, 1902) and P. nigellus (Gardner and Carter, 1972) (Chiroptera: Phyllostomidae), based on genetic, morphometric, and ecological niche analyses. Neotropical Biodiversity 4(1): 119-133. https://doi.org/10.1080/ 23766808.2018.1494481

Velazco PM, Kline KA. 2019. Tomopeas ravus (Chiroptera: Molossidae). Mammalian Species 51(979): 70-74. https://doi.org/10.1093/mspecies/sez011

Velazco PM, Lim BK. 2014. A new species of Broad-nosed bat Platyrrhinus Saussure, 1860 (Chiroptera: Phyllostomidae) from the Guianan Shield. Zootaxa 3796(1): 175-93. https://doi.org/10.11646/zootaxa.3796.1.9

Velazco PM, Patterson BD. 2013. Diversification of the Yellowshouldered bats, genus Sturnira (Chiroptera, Phyllostomidae), in the New World tropics. Molecular Phylogenetics and Evolution 68(3): 683-698. https://doi. org/10.1016/i.ympev.2013.04.016

Velazco PM, Patterson BD. 2019. Small mammals of the Mayo river basin in northern Peru, with the description of a new species of Sturnira (Chiroptera: Phyllostomidae). Bulletin of the American Museum of Natural History 429: 1-70. https://doi.org/10.1206/0003$\underline{0090.429 .1 .1}$

Velazco PM, Simmons NB. 2011. Systematics and taxonomy of Great striped-faced bats of the genus Vampyrodes Thomas, 1900 (Chiroptera: Phyllostomidae). American Museum Novitates 3710: 1-35. https://doi. org/10.1206/3710.2

Velazco PM, Soto-Centeno A, Fleck DW, et al. 2017. A new species of Nectar-feeding bat of the genus Hsunycteris (Phyllostomidae: Lonchophyllinae) from northeastern Peru. American Museum Novitates 3881: 1-26. https://doi.org/10.1206/3881.1

Velazco PM, Voss RS, Fleck DW, Simmons NB. 2021a. Mam- 
malian diversity and Matses ethnomammalogy in Amazonian Peru, Part 4: Bats. Bulletin of the American Museum of Natural History 451(1): 1-200. https:// doi.org/10.1206/0003-0090.451.1.1

Velazco PM. 2005. Morphological phylogeny of the bat genus Platyrrhinus (Chiroptera: Phyllostomidae) with the description of four new species. Fieldiana Zoology 105: 1-53. https://doi.org/10.3158/00150754(2005)105[1:MPOTBG]2.0.CO;2

Velazco PM. 2013. On the phylogenetic position of Carollia manu Pacheco et al., 2004 (Chiroptera: Phyllostomidae: Carolliinae). Zootaxa 3718(3): 267-76. https:// doi.org/10.11646/zootaxa.3718.3.3

Velazco PM. 2021. Murciélagos del Perú/Bats of Peru. Online resource. Acceso 01/08/2021. <http://www.paulvelazco.com/murcielagos_peru.html>.

Velazco S, Pacheco V, Meschede A. 2011. First occurrence of the rare emballonurid bat Cyttarops alecto (Thomas, 1913) in Peru - only hard to find or truly rare? Mammalian Biology 76(3): 373-376. https://doi. org/10.1016/i.mambio.2010.03.006

Vermeer J, Tello-Alvarado JC. 2015. The distribution and taxonomy of Titi monkeys (Callicebus) in central and southern Peru, with the description of a new species. Primate Conservation 29: 9-30. https://doi. org/10.1896/052.029.0102

Vivar E, La Rosa D. 2003. Evaluación de mamíferos de la cuenca alta del río Cenepa. Pp. 173-200. En: V Pacheco, comp. Evaluación Biológica realizada en la Cuenca del Río Cenepa Paz y Conservación Binacional en la Cordillera del Condor, Ecuador- Perú. INRENA, Perú. 160 pp.

Vivar E, Pacheco V, Valqui MH. 1997. A new species of Cryptotis (Insectivora, Soricidae) from northern Peru. American Museum Novitates 3202: 1-15. http://hdl.handle. net/2246/3606

Vivar E, Pacheco V. 2014. Estado del zorro gris Lycalopex griseus (Gray, 1837) (Mammalia: Canidae) en el Perú. Revista Peruana de Biología 21(1): 71-78. https://doi. org/10.15381/rpb.v21i1.8249

von May R, Catenazzi A, Angulo A, et al. 2012. Investigación y conservación de la biodiversidad en Perú: importancia del uso de técnicas modernas y procedimientos administrativos eficientes. Revista Peruana de Biología 19(3): 351-358. https://doi.org/10.15381/rpb. v19i3.1055

Voss RS, Díaz-Nieto JF, Jansa SA. 2018. A revision of Philander (Marsupialia, Didelphidae), Part 1: P. quica, P. canus, and a new species from Amazonia. American Museum Novitates 3891: 1-70. https://doi. org/10.1206/3891.1

Voss RS, Fleck DW, Jansa SA. 2009. On the diagnostic characters, ecogeographic distribution, and phylogenetic relationships of Gracilinanus emiliae (Didelphimorphia: Didelphidae: Thylamyini). Mastozoología Neotropical 16(2): 433-443.

Voss RS, Fleck DW, Jansa SA. 2019. Mammalian diversity and Matses ethnomammalogy in Amazonian Peru, Part 3: Marsupials (Didelphimorphia). Bulletin of the American Museum of Natural History 432: 1-90. https://doi. org/10.1206/0003-0090.432.1.1

Voss RS, Fleck DW, Strauss RE, et al. 2016. Roosting ecology of Amazonian bats: evidence for guild structure in hyperdiverse mammalian communities. American Museum Novitates 3870: 1-44. https://doi. org/10.1206/3870.1
Voss RS, Fleck DW. 2011. Mammalian diversity and Matses ethnomammalogy in Amazonian Peru, Part 1: Primates. Bulletin of the American Museum of Natural History 351: 1-81. https://doi.org/10.1206/351.1

Voss RS, Fleck DW. 2017. Mammalian diversity and Matses ethnomammalogy in Amazonian Peru, Part 2: Xenartha, Carnivora, Perisodactyla, Artiodactyla and Sirenia. Bulletin of the American Museum of Natural History 417: 1-118. https://doi.org/10.1206/00030090-417.1.1

Voss RS, Giarla TC, Díaz-Nieto JF, et al. 2020. A revision of the didelphid marsupial genus Marmosa Part 2, Species of the rapposa group (subgenus Micoureus). Bulletin of the American Museum of Natural History 439(1): 1-62. https://doi.org/10.1206/0003-0090.439.1.1

Voss RS, Giarla TC. 2020. A revision of Philander (Marsupialia: Didelphidae), Part 2: Phylogenetic relationships and morphological diagnosis of P. nigratus Thomas, 1923. American Museum Novitates 3955: 1-16. https://doi. org $/ 10.5531 /$ sd.sp.43

Voss RS, Giarla TC. 2021. A revision of the didelphid marsupial genus Marmosa, Part 3: A new species from western Amazonia, with redescriptions of M. perplexa Anthony, 1922, and M. germana Thomas, 1904. American Museum Novitates 3969: 1-28. https://doi. org $/ 10.1206 / 3969.1$

Voss RS, Gutierrez EE, Solari S, et al. 2014. Phylogenetic relationships of Mouse Opossums (Didelphidae, Marmosa) with a revised subgeneric classification and notes on sympatric diversity. American Museum Novitates 3817: 1-27. https://doi.org/10.1206/3817.1

Voss RS, Hubbard C, Jansa SA. 2013. Phylogenetic relationships of New World porcupines (Rodentia, Erethizontidae): implications for taxonomy, morphological evolution, and biogeography. American Museum Novitates 3769: 1-36. https://doi.org/10.1206/3769.2

Voss RS. 1992. A revision of the South American species of Sigmodon (Mammalia, Muridae): with notes on their natural history and biogeography. American Museum Novitates 3050: 1-56.

Voss RS. 2011. Revisionary notes on Neotropical porcupines (Rodentia: Erethizontidae) 3. An annotated checklist of species of Coendou Lacépède 1799. American Museum Novitates 3720: 1-36. https://doi. org $/ 10.1206 / 3720.2$

Voss RS. 2015a. Tribe Ichthyomyini (Vorontsov, 1959). Pp. 279290. En: JL Patton, UFJ Pardiñas, G D'Elía, eds. Mammals of South America, Volume 2: Rodents. The University of Chicago Press, Chicago, IL, USA. xxvi + 1336 pp.

Voss RS. 2015b. Genus Pseudoryzomys. Pp. 444-445. En: JL Patton, UFJ Pardiñas, G D'Elía, eds. Mammals of South America, Volume 2: Rodents. The University of Chicago Press, Chicago, IL, USA. xxvi + 1336 pp.

Voss RS. 2015c. Superfamily Erethizontoidea Bonaparte, 1845. Pp. 786-804. En: JL Patton, UFJ Pardiñas, G D'Elía, eds. Mammals of South America, Volume 2: Rodents. The University of Chicago Press, Chicago, IL, USA. xxvi + $1336 \mathrm{pp}$.

Weksler M, Lóss S. 2015. Genus Melanomys Thomas, 1902. Pp. 348-354. En: JL Patton, UFJ Pardiñas, G D'Elía, eds. Mammals of South America, Volume 2: Rodents. The University of Chicago Press, Chicago, IL, USA. xxvi + $1336 \mathrm{pp}$.

Weksler M. 2003. Phylogeny of Neotropical oryzomyine rodents (Muridae: Sigmodontinae) based on the nuclear 
IRBP exon. Molecular Phylogenetics and Evolution 29(2): 331-349. https://doi.org/10.1016/S10557903(03)00132-5

Wetzel RM, Gardner AL, Redford KH, et al. 2008. Order Cingulata Illiger, 1811. Pp. 128-157. En: Gardner AL, Ed. Mammals of South America, Volume 1: Marsupials, Xenarthrans, Shrews, and Bats. The University of Chicago Press, Chicago, IL, USA. xx + 669 pp. https://doi. org/10.7208/chicago/9780226282428.001.0001

Wilson DE, Lacher TE Jr., Mittermeier RA, eds. 2016. Handbook of the Mammals of the World. Vol. 6. Lagomorphs and Rodents I. Lynx Edicions, Barcelona. 986 pp.

Wilson DE, Lacher TE Jr., Mittermeier RA, eds. 2017. Handbook of the Mammals of the World. Vol. 7. Rodents II. Lynx Edicions, Barcelona. 1008 pp.

Wilson DE, Mittermeier RA, eds. 2009. Handbook of the Mammals of the World. Vol. 1. Carnivores. Lynx Edicions, Barcelona. 727 pp.

Wilson DE, Mittermeier RA, eds. 2011. Handbook of the Mammals of the World. Vol. 2. Hoofed Mammals. Lynx Edicions, Barcelona. 885 pp.

Williams SL, Genoways HH. 2008. Pp. 255-300. Subfamily Phyllostominae. En: Gardner AL, ed. Mammals of South America, Volume 1: Marsupials, Xenarthrans, Shrews, and Bats. The University of Chicago Press, Chicago, IL, USA. $x x+669$ pp.

Willig MR, Presley SJ, Bloch CP, et al. 2007. Phyllostomid bats of lowland Amazonia: effects of habitat alteration on abundance. Biotropica 39(6): 737-746. https://doi. org/10.1111/j.1744-7429.2007.00322.x

Zamora-Gutierrez V, Ortega J. 2020. Lichonycteris obscura (Chiroptera: Phyllostomidae). Mammalian Species 52(999): 165-172. https://doi.org/10.1093/mspecies/seaa012

Zeballos H, Cristóbal LH, Arias S, et al. 2019a. New record of Marmosa (Stegomarmosa) andersoni Gray, 1821 (Didelphimorphia, Didelphidae), a rare and endemic Peruvian marsupial. Check List 15(1): 119-123. https:// doi.org/10.15560/15.1.119

Zeballos H, Medina CE, Rico-Cernohorska A, Salazar-Bravo J. 2021. Una nueva especie de Oxymycterus (Cricetidae: Sigmodontinae: Akodontini) del sureste del Perú. Mastozoología Neotropical 28(1): e0545. https://doi. org/10.31687/saremMN.21.28.1.0.26

Zeballos H, Palma Vásquez RE, Marquet PA. 2014. Phylogenetic relationships of Calomys sorellus complex (Rodentia: Cricetidae), with the description of two new species. Revista Mexicana de Mastozoología Nueva Época 4(1): 1-23. https://doi.org/10.22201/ ie.20074484e.2014.4.1.188

Zeballos H, Pari A, Pino K, et al. 2018b. First record of the Andean-mountain cavy Microcavia niata (Caviidae, Rodentia) from Peru. Gayana 82(1): 85-89. https://doi. org/10.4067/S0717-65382018000100085

Zeballos H, Pino K, Ludeña JP, et al. 2019b. New records of the Peruvian crevice-dwelling bat Tomopeas ravus (Chiroptera: Molossidae): What do they mean for its conservation?. Mastozoología Neotropical 26(1): 199-211. https://doi.org/10.31687/saremMN.19.26.1.0.15

Zeballos H, Pino K, Medina CE, et al. 2018a. A new species of small-eared shrew of the genus Cryptotis (Mammalia, Eulipotyphla, Soricidae) from the northernmost Peruvian Andes. Zootaxa 4377(1): 51-73. https://doi. org/10.11646/zootaxa.4377.1.4
Zeballos H, Villegas L, Gutiérrez R, et al. 2000. Vertebrados de las Lomas de Atiquipa y Mejía, sur del Perú. Revista de Ecología Latinoamericana 7(3): 11-15.

Zeballos-Patrón H, Pacheco V, Baraybar L. 2001. Diversidad y conservación de los mamíferos de Arequipa, Perú. Revista Peruana de Biología 8(2): 94-104. https://doi. org/10.15381/rpb.v8i2.6564

Zegarra 0, Pacheco J, Pacheco V. 2020. Distributional patterns of the Brazilian free-tailed bat Tadarida brasiliensis in the Peruvian territory. Therya 11(3): 495-507. https://doi.org/10.12933/therya-20-995

\section{Agradecimientos / Acknowledgments:}

Nuestro agradecimiento a colegas y estudiantes, especialmente a Daniel Llancachahua y José Martínez, quienes que apoyaron revisando la lista de especies o las referencias, y a Blanca León por sus ediciones y comentarios.

\section{Conflicto de intereses / Competing interests:}

Los autores no incurren en conflictos de intereses.

\section{Rol de los autores / Authors Roles:}

VP: conceptualización, Investigación, Análisis formal, EscrituraPreparación del borrador original, Redacción: revisión y edición. SD, LGA, MFQ, GCM, DR y PSV: Investigación, Análisis formal, Redacción: revisión y edición. Todos los autores contribuyeron en la escritura, análisis de datos, revisión del manuscrito y dieron su aprobación a su versión final.

\section{Fuentes de financiamiento / Funding:}

Este trabajo se realizó con financiamiento parcial del Vicerrectorado de Investigación y Posgrado de la Universidad Nacional Mayor de San Marcos al grupo de Investigación DIMAPA (proyectos B2010032, B21100031).

\section{Aspectos éticos / legales; Ethics / legals:}

Los autores declaran que no violaron ni omitieron normas éticas o legales en esta investigación. 
Página en banco

Blank page 
Apéndice 1. Lista de especies de mamíferos registrados para el Perú con distribución por ecorregiones (sensu Brack-Egg, 1986). Cada especie está sustentada por al menos una referencia bibliográfica. Las abreviaturas empleadas son: OCE, Oceánica; BPP, Bosque Pluvial del Pacífico; BSE, Bosque Seco Ecuatorial; COS, Costa; VOC, Vertiente Occidental; PAR, Páramo; PUN, Puna; YUN Yungas; SB, Selva Baja; SP, Sabana de Palmera; END, Especie endémica.

\begin{tabular}{|c|c|c|c|c|c|}
\hline & Nombre científico & Nombre común & Ecorregiones & End & Referencias \\
\hline \multicolumn{6}{|c|}{ Subclase Theria } \\
\hline \multicolumn{6}{|c|}{ Infraclase Marsupialia } \\
\hline \multicolumn{6}{|c|}{ Didelphimorphia (47) } \\
\hline \multicolumn{6}{|c|}{ Didelphidae (47) } \\
\hline 1 & Caluromys lanatus (Olfers, 1818) & Zarigüeyita lanuda & YUN, SB, SP & & Voss \& Fleck 2017, Voss et al. 2019 \\
\hline 2 & Caluromysiops irrupta Sanborn, 1951 & Zarigüeyita de estola negra & SB & & Pacheco et al. 2011, Barbosa et al. 2015 \\
\hline 3 & Glironia venusta Thomas, 1912 & Zarigüeyita de cola poblada & SB & & Diaz \& Willig 2004, Barkley 2008 \\
\hline 4 & Chironectes minimus (Zimmermann, 1780) & Zarigüeyita acuática & YUN, SB & & Boddicker et al. 2001, Prieto-Torres \& Pinilla-Buitrago 2017 \\
\hline 5 & Cryptonanus unduaviensis (Tate, 1931) & Marmosa grácil boliviana & $S P$ & & Medina et al. 2016b \\
\hline 6 & Didelphis marsupialis Linnaeus, 1758 & Zarigüeya de orejas negras & $B P P, B S E, Y U N, S B$ & & Ruelas et al. 2016b, Pacheco et al. 2020a \\
\hline 7 & Didelphis pernigra J. A. Allen, 1900 & Zarigüeya andina, zarigüeya de orejas blancas & COS, VOC, YUN & & Pacheco et al. 2013, Pacheco et al. 2020b \\
\hline 8 & Gracilinanus aceramarcae (Tate, 1931) & Marmosa grácil de Aceramarca & YUN & & Pacheco et al. 2013, Pacheco et al. 2020a \\
\hline 9 & Gracilinanus emiliae (Thomas, 1909) & Comadrejita marsupial de Emilia & SB & & Voss et al. 2009, Giarla et al. 2010 \\
\hline 10 & Gracilinanus peruanus (Tate, 1931) & Comadrejita marsupial ágil & SB & & Huamaní et al. 2009, Voss et al. 2019 \\
\hline 11 & Hyladelphys kalinowskii (Hershkovitz, 1992) & Marmosa grácil de Kalinowski & SB & & Hice \& Velazco 2012, Voss et al. 2019 \\
\hline 12 & Lutreolina crassicaudata (Desmarest, 1804) & Comadreja colorada, zarigüeya de cola gruesa & SP & & Emmons et al. 2002, Medina et al. 2016b \\
\hline 13 & Marmosa (Eomarmosa) rubra Tate, 1931 & Comadrejita marsupial rojiza & SB & & Rossi et al. 2010b, Pacheco et al. 2011 \\
\hline 14 & Marmosa (Exulomarmosa) simonsi Thomas, 1899 & Comadrejita marsupial de Simons & $B P P, B S E, V O C$ & & Pacheco et al. 2009, Rossi et al. 2010b \\
\hline 15 & Marmosa (Marmosa) macrotarsus (Wagner, 1842) & Zarigüeya ratón quechua & YUN, SB & & Ruelas et al. 2016a, Voss et al. 2019 \\
\hline 16 & Marmosa (Marmosa) waterhousei (Tomes, 1860) & Comadrejita marsupial de Waterhouse & SB & & Voss et al. 2019, Pacheco et al. 2020a \\
\hline 17 & Marmosa (Micoureus) constantiae Thomas, 1904 & Comadrejita marsupial lanuda & YUN, SB & & Voss et al. 2019, Pacheco et al. 2020a \\
\hline 18 & Marmosa (Micoureus) germana Thomas, 1904 & Comadrejita marsupial lanuda & SB & & Voss et al. 2019 \\
\hline 19 & Marmosa (Micoureus) jansae Voss \& Giarla, 2021 & Comadrejita marsupial lanuda de Jansa & SB & & Voss \& Giarla 2021 \\
\hline 20 & Marmosa (Micoureus) parda Tate, 1931 & Comadrejita marsupial lanuda parda & YUN & E & Voss et al. 2020 \\
\hline 21 & Marmosa (Micoureus) perplexa Anthony, 1922 & Comadrejita marsupial lanuda & BPP & & Voss et al. 2020 \\
\hline 22 & Marmosa (Micoureus) rapposa Thomas, 1899 & Comadrejita marsupial lanuda & YUN, SB & & Voss et al. 2020 \\
\hline 23 & Marmosa (Micoureus) rutteri Thomas, 1924 & Comadrejita marsupial lanuda de Rutter & YUN, SB, SP & & Voss et al. 2020, Pacheco et al. 2020a \\
\hline 24 & Marmosa (Stegomarmosa) andersoni Pine, 1972 & Comadrejita marsupial de Anderson & YUN, SB & $\mathrm{E}$ & Voss et al. 2014, Zeballos et al. 2019a \\
\hline 25 & Marmosa (Stegomarmosa) lepida (Thomas, 1888) & Comadrejita marsupial radiante & YUN, SB, SP & & Voss et al. 2019, Pacheco et al. 2020a \\
\hline 26 & Marmosops (Marmosops) caucae (Thomas, 1900) & Comadrejita marsupial mantequera & YUN, SB & & Díaz-Nieto et al. 2016, Pacheco et al. 2020a \\
\hline 27 & Marmosops (Marmosops) noctivagus (Tschudi, 1845) & Comadrejita marsupial noctámbula & BPP, YUN, SB, SP & & Medina et al. 2016b, Medina et al. 2017 \\
\hline 28 & Marmosops (Marmosops) soinii Voss, Fleck \& Jansa, 2019 & Comadrejita marsupial de Soini & SB & $\mathrm{E}$ & Voss et al. 2019 \\
\hline 29 & Marmosops (Sciophanes) bishopi (Pine, 1981) & Comadrejita marsupial de Bishop & YUN, SB, SP & & Pacheco \& Noblecilla 2019, Pacheco et al. 2020a \\
\hline 30 & Marmosops (Sciophanes) juninensis (Tate, 1931) & Comadrejita marsupial de Junín & YUN & $\mathrm{E}$ & Peralta \& Pacheco 2014, Díaz-Nieto \& Voss 2016 \\
\hline 31 & Metachirus myosuros (Temminck, 1824) & Rata marsupial de cuatro ojos & YUN, SB & & Voss et al. 2019 \\
\hline 32 & Monodelphis (Microdelphys) gardneri Solari, Pacheco, Vivar \& Emmons, 2012 & Colicorto marsupial de Gardner & YUN & $\mathrm{E}$ & Pavan \& Voss 2016, Pacheco \& Noblecilla 2019 \\
\hline 33 & Monodelphis (Monodelphis) glirina (Wagner, 1842) & Colicorto de flancos rojos & SB & & Ruelas et al. 2016a, Pavan 2019 \\
\hline 34 & Monodelphis (Mygalodelphys) adusta (Thomas, 1897) & Marsupial sepia de cola corta & YUN, SB & & Pavan \& Voss 2016, Pacheco et al. 2020a \\
\hline 35 & Monodelphis (Mygalodelphys) handleyi Solari, 2007 & Colicorto marsupial de Handley & SB & $\mathrm{E}$ & Solari 2007 \\
\hline 36 & Monodelphis (Mygalodelphys) osgoodi Doutt, 1938 & Colicorto marsupial de Osgood & YUN & & Solari 2004, Solari 2007 \\
\hline 37 & Monodelphis (Mygalodelphys) peruviana (Osgood, 1913) & Colicorto marsupial peruano & YUN, SB, SP & & Pavan \& Voss 2016, Pacheco et al. 2020a \\
\hline 38 & Monodelphis (Mygalodelphys) ronaldi Solari, 2004 & Colicorto marsupial de Ronald & SB & $\mathrm{E}$ & Solari 2004 \\
\hline 39 & Monodelphis (Pyrodelphys) emiliae (Thomas, 1912) & Colicorto marsupial de Emilia & SB & & Medina et al. 2015, Pavan \& Voss 2016 \\
\hline 40 & Philander andersoni (Osgood, 1913) & Zarigüeyita negra de Anderson & SB & & Flores et al. 2008 , Voss et al. 2018 \\
\hline 41 & Philander canus (Osgood, 1913) & Zarigüeyita negra de cuatro ojos & SB & & Flores et al. 2008, Voss et al. 2018 \\
\hline 42 & Philander mcilhennyi Gardner \& Patton, 1972 & Zarigüeyita de cola poblada & SB & & Quintana et al. 2009, Voss et al. 2018 \\
\hline 43 & Philander nigratus (Thomas, 1923) & Zarigüeyita negra & YUN & $\mathrm{E}$ & Voss \& Giarla 2020 \\
\hline 44 & Philander pebas Voss, Diaz-Nieto \& Jansa, 2018 & Zarigüeyita de Pebas & SB & & Voss et al. 2018, Voss et al. 2019 \\
\hline 45 & Thylamys (Thylamys) pallidior (Thomas, 1902) & Marmosa coligruesa de vientre blanco & COS, VOC, PUN & & Giarla et al. 2010, Palma et al. 2014 \\
\hline 46 & Thylamys (Thylamys) tatei (Handley, 1957) & Marmosa coligruesa de Tate & $\cos , \mathrm{voc}$ & $\mathrm{E}$ & Giarla et al. 2010, Palma et al. 2014 \\
\hline 47 & Thylamys (Thylamys) sp. & - & COS VOC PUN & $\mathrm{F}$ & Palma et al. 2014. Pacheco et al. 202 \\
\hline
\end{tabular}

Paucituberculata (2)

Caenolestidae (2)

Caenolestes caniventer Anthony, 1921

Musaraña marsupial de vientre gris

PAR, YUN

Lunde \& Pacheco 2003, Ojala-Barbour et al. 2013

Lestoros inca (Thomas, 1917)

Musaraña marsupial incaica

YUN

Myers \& Patton 2008, Ojala-Barbour et al. 2013

Infraclase Placentalia

Superorden Afrotheria

Sirenia (1)

Trichechidae (1)

$50 \quad$ Trichechus inunguis (Natterer, 1883)

Manatí amazónico

SB

Marmontel et al. 2012, Satizábal et al. 2012

Cingulata (5)

Dasypodidae (3)

$51 \quad$ Dasypus novemcinctus Linnaeus, 1758

52 Dasypus pastasae (Thomas, 1901)

$53 \quad$ Dasypus pilosus (Fitzinger, 1856)

Chlamyphoridae (2)

$54 \quad$ Cabassous unicinctus (Linnaeus, 1758)

55 Priodontes maximus (Kerr, 1792)

Armadillo de nueve bandas, carachupa

Armadillo de Pastaza

Armadillo peludo, quirquincho peludo, tatú peludoPAR, YUN
Medina et al. 2016b, Voss \& Fleck 2017

Wetzel et al. 2008, Abba \& Supperina 2010

E Castro et al. 2015, Feng et al. 2017

\begin{tabular}{|c|c|c|}
\hline Armadillo de cola desnuda & SB & Ruelas et al. 2016b, Pacheco et al. 2020a \\
\hline Armadillo gigante, carachupa & $S B, S P$ & Aquino et al. 2012, Ruelas et al. 2016b \\
\hline
\end{tabular}




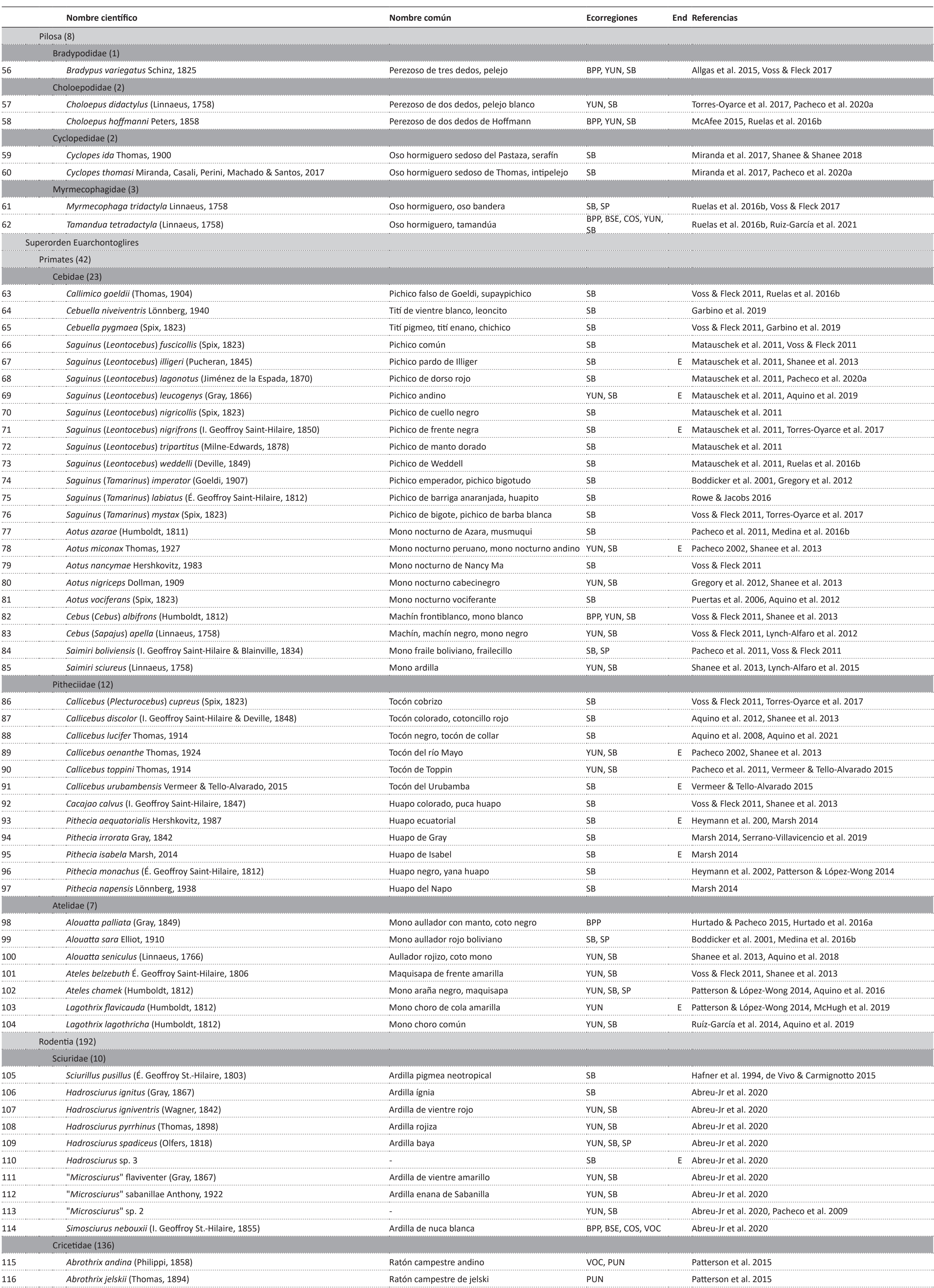


PACHECO Et AL.

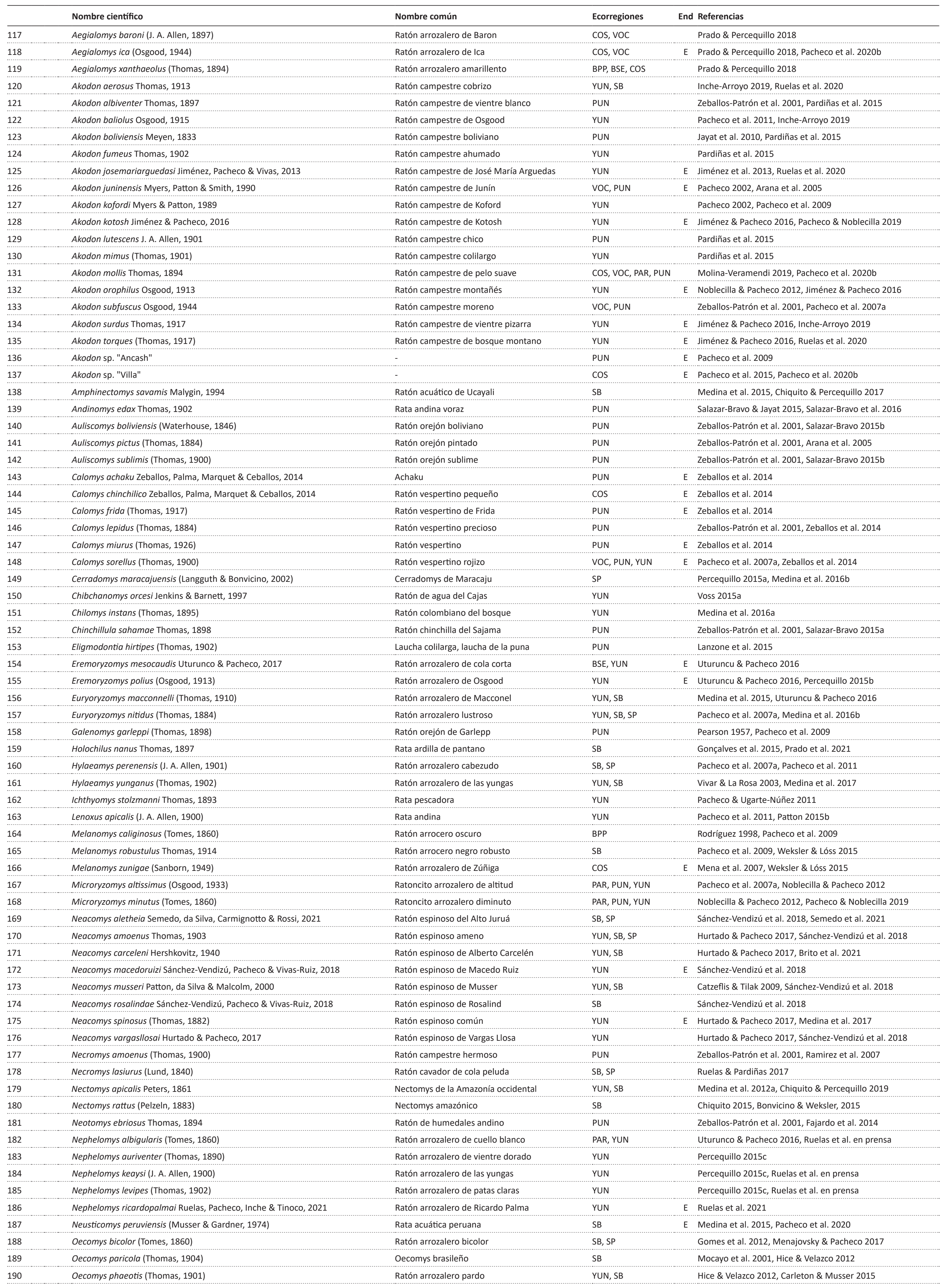




\begin{tabular}{|c|c|c|c|c|c|}
\hline & Nombre científico & Nombre común & Ecorregiones & End & Referencias \\
\hline 191 & Oecomys roberti (Thomas, 1904) & Ratón arrozalero amazónico & SB & & Carleton \& Musser 2016 \\
\hline 192 & Oecomys superans Thomas, 1911 & Ratón arrozalero selvático & SB & & Solari et al. 2001, Carleton \& Musser 2016 \\
\hline 193 & Oecomys trinitatis (J. A. Allen \& Chapman, 1893) & Ratón arrozalero peludo & SB & & Ruelas et al. 2016a, Carleton \& Musser 2016 \\
\hline 195 & Oligoryzomys arenalis (Thomas, 1913) & Ratón arrozalero de los arenales & cos, voc & E & Hurtado 2021; Pacheco et al. 2020b \\
\hline 196 & Oligoryzomys destructor (Tschudi, 1844) & Ratón arrozalero destructor & YUN, SB & & Medina et al. 2017, Pacheco \& Noblecilla 2019 \\
\hline 197 & Oligoryzomys guille Hurtado, 2021 & Ratón arrozalero de Guillermo D’Elía & cos, voc & E & Hurtado 2021, Pacheco et al. 2020b \\
\hline 198 & Oligoryzomys microtis (J. A. Allen, 1916) & Ratón arrozalero de oreja pequeña & $\mathrm{SB}, \mathrm{SP}$ & & Pacheco et al. 2007a, Medina et al. 2016b \\
\hline 200 & Oligoryzomys sp. C & - & YUN & E & Carleton \& Musser 1989, Pacheco et al. 2009 \\
\hline 201 & Oreoryzomys balneator (Thomas, 1900) & Ratón arrozalero ecuatoriano & PAR, YUN & & Weksler 2003, Sánchez-Vendizú et al. 2018 \\
\hline 202 & Oxymycterus hiska Hinojosa, Anderson \& Patton, 1987 & Ratón hocicudo menor & YUN & & Pacheco 2002, de Oliveira \& Gonçalves 2015 \\
\hline 203 & Oxymycterus inca Thomas, 1900 & Ratón hocicudo Inca & YUN, SB & & Gregory et al. 2016, Ruelas \& Pacheco 2021b \\
\hline 204 & Oxymycterus juliacae J. A. Allen, 1900 & Hocicudo Inca de las Yungas, hocicudo de Juliaca & YUN & & de Oliveira \& Gonçalves 2015, Ruelas \& Pacheco 2021b \\
\hline 205 & Oxymycterus nigrifrons Osgood, 1944 & Hocicudo de los bosques enanos & YUN & & de Oliveira \& Gonçalves 2015 \\
\hline 206 & Oxymycterus paramensis Thomas, 1902 & Hocicudo parameño & PUN & & de Oliveira \& Gonçalves 2015 \\
\hline 207 & Oxymycterus willkaurco Zeballos, Medina, Rico-Cernohorska \& Salazar-Bravo, 2021 & Hocicudo del Cusco & PUN, YUN & E & Zeballos et al. 2021, Ruelas \& Pacheco 2021b \\
\hline 209 & Phyllotis andium Thomas, 1912 & Ratón orejón andino & COS, VOC, PUN & & Arana et al. 2005, Rengifo \& Pacheco 2015 \\
\hline 210 & Phyllotis definitus Osgood, 1915 & Ratón orejón definido & VOC, PUN & E & Pacheco 2002 \\
\hline 211 & Phyllotis gerbillus Thomas, 1900 & Ratón orejón gerbito & $\mathrm{BSE}, \mathrm{COS}$ & E & Pacheco et al. 2014, Steppan \& Ramirez 2015 \\
\hline 212 & Phyllotis limatus Thomas, 1912 & Ratón orejón de Lima & COS, VOC, PUN & & Steppan et al. 2007, Steppan \& Ramirez 2015 \\
\hline 213 & Phyllotis magister Thomas, 1912 & Ratón orejón maestro & VOC, PUN & & Zeballos-Patrón et al. 2001, Steppan et al. 2007 \\
\hline 214 & Phyllotis occidens Rengifo \& Pacheco, 2015 & Ratón orejón de occidente & cos, vOC & E & Rengifo \& Pacheco 2015 \\
\hline 215 & Phyllotis osilae J. A. Allen, 1901 & Ratón orejón de Asillo & PUN & & Zeballos-Patrón et al. 2001, Steppan et al. 2007 \\
\hline 216 & Phyllotis pearsoni Pacheco, Rengifo \& Vivas, 2015 & Ratón orejón de Pearson & PUN & E & Pacheco et al. 2014, Rengifo \& Pacheco 2015 \\
\hline 217 & Phyllotis stenops Osgood, 1914 & Ratón orejón de nasal estrecho & YUN & E & Rengifo \& Pacheco 2015 \\
\hline 218 & Phyllotis xanthopygus (Waterhouse, 1837) & Ratón orejón de ancas amarillentas & VOC, PUN & & Zeballos-Patrón et al. 2001, Steppan et al. 2007 \\
\hline 219 & Pseudoryzomys simplex (Winge, 1887) & Falso ratón arrozalero del Brasil & SB, SP & & Voss 2015b, Medina et al. 2016b \\
\hline 220 & Punomys kofordi Pacheco \& Patton, 1995 & Ratón puneño de Koford & PUN & & Patton 2015a, Salazar-Bravo et al. 2016 \\
\hline 221 & Punomys lemminus Osgood, 1943 & Ratón puneño & PUN & E & Pacheco 2002, Patton 2015a \\
\hline 222 & Rhagomys longilingua Luna \& Patterson, 2003 & Rhagomys de lengua larga & YUN, SB & & Luna \& Patterson 2003, Medina et al. 2017 \\
\hline 223 & Rhipidomys gardneri Patton, da Silva \& Malcolm, 2000 & Rata trepadora de Gardner & YUN, SB & & Medina et al. 2012a, Tribe 2015 \\
\hline 224 & Rhipidomys latimanus Tomes, 1860 & Rata trepadora de pies anchos & YUN & & Tribe 2015 \\
\hline 225 & Rhipidomys leucodactylus (Tschudi, 1845) & Rata de las Chirimoyas & $\begin{array}{l}\text { BPP, BSE, VOC, YUN, } \\
\text { SB }\end{array}$ & & Pacheco \& Peralta 2011, Tribe 2015 \\
\hline 228 & Rhipidomys sp. & - & YUN & & Jiménez \& Pacheco 2012 \\
\hline 229 & Scolomys melanops Anthony, 1924 & Ratón espinoso ecuatoriano & SB & & Vivar \& La Rosa 2003, Medina et al. 2015 \\
\hline 230 & Scolomys ucayalensis Pacheco, 1991 & Ratón espinoso del Ucayali & SB & & Pacheco 1991, Medina et al. 2015 \\
\hline 231 & Sigmodon peruanus J. A. Allen, 1897 & Rata algodonera peruana & BPP, BSE, COS & & Voss 1992, Pacheco et al. 2009 \\
\hline 232 & Thomasomys antoniobracki Ruelas \& Pacheco, 2021 & Ratón montaraz de Antonio Brack & YUN & E & Ruelas \& Pacheco 2021c \\
\hline 233 & Thomasomys apeco Leo L. \& Gardner, 1993 & Ratón montaraz de Apeco & YUN & E & Pacheco 2002, Pacheco 2015 \\
\hline 234 & Thomasomys aureus (Tomes, 1860) & Ratón montaraz dorado & PAR, YUN & & Pacheco 2015, Pacheco 2021 \\
\hline 235 & Thomasomys caudivarius Anthony, 1923 & Ratón montaraz de cola variada & PAR, YUN & & Pacheco et al. 2009, Pacheco 2015 \\
\hline 236 & Thomasomys cinereus (Thomas, 1882) & Ratón montaraz ceniciento & VOC, PAR, YUN & & Pacheco et al. 2009, Pacheco 2015 \\
\hline 237 & Thomasomys daphne Thomas, 1917 & Ratón montaraz de Dafne & YUN & & Ramirez et al. 2007, Pacheco 2015 \\
\hline 238 & Thomasomys eleusis Thomas, 1926 & Ratón montaraz peruano & YUN & E & Pacheco 2015 \\
\hline 239 & Thomasomys gracilis Thomas, 1917 & Ratón montaraz delicado & YUN & E & Pacheco 2015 \\
\hline 240 & Thomasomys incanus (Thomas, 1894) & Ratón montaraz incaico & PUN, YUN & E & Pacheco 2002, Pacheco 2015 \\
\hline 241 & Thomasomys ischyrus Osgood, 1914 & Ratón montaraz de Amazonas & PUN, YUN & E & Pacheco 2015, Pacheco \& Noblecilla 2019 \\
\hline 242 & Thomasomys kalinowskii (Thomas, 1894) & Ratón montaraz de Kalinowski & YUN & E & Pacheco 2015, Pacheco \& Noblecilla 2019 \\
\hline 243 & Thomasomys macrotis Gardner \& Romo, 1993 & Ratón montaraz orejón & YUN & E & Gardner \& Romo 1993, Pacheco 2015 \\
\hline 244 & Thomasomys notatus Thomas, 1917 & Ratón montaraz marcado & YUN & E & Pacheco 2015, Pacheco \& Noblecilla 2019 \\
\hline 245 & Thomasomys onkiro Luna \& Pacheco, 2002 & Ratón montaraz ashaninka & YUN & E & Luna \& Pacheco 2002, Pacheco 2015 \\
\hline 246 & Thomasomys oreas Anthony, 1926 & Ratón montaraz dorado pequeño & YUN & & Pacheco 2015, Sahley et al. 2015 \\
\hline 247 & Thomasomys praetor (Thomas, 1900) & Ratón montaraz de Cajamarca & voc & E & Pacheco 2015 \\
\hline 248 & Thomasomys pyrrhonotus Thomas, 1886 & Ratón montaraz de dorso rojizo & VOC, PAR, YUN & E & Pacheco 2015 \\
\hline 249 & Thomasomys rosalinda Thomas \& St. Leger, 1926 & Ratón montaraz rosalinda & YUN & $\mathrm{E}$ & Pacheco 2002 \\
\hline 250 & Thomasomys taczanowskii (Thomas, 1882) & Ratón montaraz de Taczanowski & VOC, PAR, YUN & & Pacheco 2002, Pacheco 2015 \\
\hline \multirow[t]{2}{*}{251} & Transandinomys talamancae (J. A. Allen, 1891) & Ratón arrozalero de Talamanca & BPP & & Pacheco et al. 2009, Carleton 2015 \\
\hline & \multicolumn{5}{|l|}{ Erethizontidae (4) } \\
\hline 252 & Coendou bicolor (Tschudi, 1844) & Puercoespín arborícola, erizo, casha cushillo & VOC, YUN, SB & & Voss et al. 2013, Gregory et al. 2015 \\
\hline 253 & Coendou ichillus Voss \& da Silva, 2001 & Puercoespín pequeño ecuatoriano & SB & & Voss et al. 2013, Gregory et al. 2015 \\
\hline 254 & Coendou prehensilis (Linnaeus, 1758) & Puercoespín brasileño & SB & & Voss 2011, Voss et al. 2013 \\
\hline \multirow[t]{2}{*}{255} & Coendou rufescens (Gray, 1865) & Puercoespín de cola corta & BSE, VOC, YUN & & Voss 2015c, More \& Crespo 2017 \\
\hline & \multicolumn{5}{|l|}{ Chinchillidae (3) } \\
\hline 256 & Chinchilla chinchilla (Lichtenstein, 1830) & Chinchilla & PUN & & Spotorno \& Patton 2015 \\
\hline 257 & Lagidium viscacia (G. I. Molina, 1782) & Vizcacha & COS, VOC, PUN & & Zeballos et al. 2000, Spotorno \& Patton 2015 \\
\hline 258 & Lagostomus crassus Thomas, 1910 & Vizcacha de los Ilanos peruanos & YUN & E & Spotorno \& Patton 2015 \\
\hline
\end{tabular}


PACHECO ET AL.

\begin{tabular}{|c|c|c|c|c|c|}
\hline & Nombre científico & Nombre común & Ecorregiones & End & Referencias \\
\hline 261 & Cavia porcellus (Linnaeus, 1758) & Cuy doméstico, cochinillo de Indias & COS, VOC, PUN & & Zeballos-Patrón et al. 2001, Pacheco et al. 2009 \\
\hline 262 & Cavia tschudii Fitzinger, 1867 & Cuy silvestre, poronccoy & COS, VOC, PAR, PUN & & Pacheco et al. 2015, Pacheco et al. 2020b \\
\hline 263 & Microcavia niata (Thomas, 1898) & Cuy del Altiplano & PUN & & Zeballos et al. 2018b \\
\hline \multirow[t]{2}{*}{265} & Hydrochoerus hydrochaeris (Linnaeus, 1766) & Ronsoco, capibara, ivéto & SB, SP & & Moreira et al. 2013, Patterson \& López-Wong 2014 \\
\hline & isyproctidae (5) & & & & \\
\hline 266 & Dasyprocta fuliginosa Wagler, 1832 & Añuje, chapana, cutpe & YUN, SB & & Aquino et al. 2012, Torres-Oyarce et al. 2017 \\
\hline 267 & Dasyprocta kalinowskii Thomas, 1897 & Agutí de Kalinowski, sihuro, añuje, cutpe & YUN & $\mathrm{E}$ & Pacheco et al 2007, Patton \& Emmons 2015 \\
\hline 268 & Dasyprocta punctata Gray, 1842 & Agutí & BPP & & Hurtado \& Pacheco 2015 \\
\hline 269 & Dasyprocta variegata Tschudi, 1845 & Añuje, cutpe, agutí & YUN, SB, SP & & Quintana et al. 2009, Patton \& Emmons 2015 \\
\hline \multirow[t]{2}{*}{270} & Myoprocta pratti Pocock, 1913 & Punchana, añuje menor & SB & & Quintana et al. 2009, Patton \& Emmons 2015 \\
\hline & Iniculidae (2) & & & & \\
\hline 271 & Cuniculus paca (Linnaeus, 1766) & Majaz, picuro, zamaño, liebre, samani & $B P P, B S E, Y U N, S B$ & & Amanzo 2003, Gonzales \& Llerena 2014 \\
\hline \multirow[t]{2}{*}{272} & Cuniculus taczanowskii (Stolzmann, 1865) & Paca de Taczanowski, majaz de montaña & PAR, YUN & & Jiménez et al. 2010, Medina et al. 2012a \\
\hline & enomyidae (3) & & & & \\
\hline 273 & Ctenomys leucodon Waterhouse, 1848 & Tucu-tucu de dientes blancos & PUN & & Bidau 2015 \\
\hline 274 & Ctenomys opimus Wagner, 1848 & Tucu-tucu del Titicaca & VOC, PUN & & Bidau 2015 \\
\hline 275 & rocomidae (3) & & & & \\
\hline 276 & Abrocoma cinerea Thomas, 1919 & Rata chinchilla cenicienta & PUN & & Zeballos-Patrón et al. 2001 \\
\hline 277 & Cuscomys ashaninka Emmons, 1999 & Rata chinchilla arborícola ashaninka & YUN & E & Emmons 1999, Ochoa et al. 2020 \\
\hline \multirow[t]{2}{*}{278} & Cuscomys oblativus (Eaton, 1916) & Rata chinchilla arborícola de Machu Picchu & YUN & $\mathrm{E}$ & Pacheco et al. 2009, Ochoa et al. 2020 \\
\hline & himyidae (20) & & & & \\
\hline 279 & Dactylomys boliviensis Anthony, 1920 & Cono-cono boliviano & YUN, SB & & Quintana et al. 2009, Emmons et al. 2015a \\
\hline 280 & Dactylomys dactylinus (Desmarest, 1817) & Cono-cono amazónico & SB & & Solari et al. 2006, Emmons et al. 2015a \\
\hline 281 & Dactylomys peruanus J. A. Allen, 1900 & Cono-cono peruano & YUN & & Emmons et al. 2015a \\
\hline 282 & Echimys saturnus Thomas, 1928 & Rata de espinas oscuras & $S B, Y U N$ & & Emmons et al. 2015b, Juárez-Pérez et al. 2021 \\
\hline 283 & Isothrix barbarabrownae Patterson \& Velazco, 2006 & Toró de Barbara Brown & YUN & E & Patterson \& Velazco 2006 \\
\hline 284 & Isothrix bistriata Wagner, 1845 & Rata de doble estría & SB & & Patton et al. 2000 \\
\hline 285 & Leiuromys occasius (Thomas, 1921) & Rata arborícola de cola desnuda & SB & & Emmons \& Fabre 2018 \\
\hline 286 & Makalata macrura (Wagner, 1842) & Rata espinosa de árbol & SB & & Patton et al. 2000, Emmons \& Patton 2015 \\
\hline 287 & Toromys albiventris Emmons \& Fabre, 2018 & Rata espinosa de vientre blanco & SB & E & Emmons \& Fabre 2018 \\
\hline 288 & Toromys rhipidurus (Thomas, 1928) & Rata espinosa peruana & SB & & Emmons \& Fabre 2018 \\
\hline 289 & Mesomys hispidus (Desmarest, 1817) & Rata espinosa áspera de río Madeira & $S B, S P$ & & Vivar \& La Rosa 2003, Hice \& Velazco 2012 \\
\hline 290 & Mesomys leniceps Thomas \& St. Leger, 1926 & Rata espinosa áspera peruana & YUN & E & Pacheco et al. 2009 \\
\hline 293 & Proechimys decumanus (Thomas, 1899) & Rata espinosa grande & BPP, BSE & & Patton \& Leite 2015 \\
\hline 294 & Proechimys kulinae da Silva, 1998 & Rata espinosa de Kulina & SB & & Medina et al. 2015, Patton \& Leite 2015 \\
\hline 295 & Proechimys pattoni da Silva, 1998 & Rata espinosa de Patton & SB & & Ruelas et al. 2016a \\
\hline 296 & Proechimys quadruplicatus Hershkovitz, 1948 & Rata espinosa del Napo & SB & & Patton et al. 2000, Patton \& Leite 2015 \\
\hline 297 & Proechimys simonsi Thomas, 1900 & Rata espinosa de Simons & YUN, SB, SP & & Hice \& Velazco 2012, Patton \& Leite 2015 \\
\hline \multirow[t]{3}{*}{298} & Proechimys steerei Goldman, 1911 & Rata espinosa de Steer & SB & & Quintana et al. 2009 \\
\hline & orpha (2) & & & & \\
\hline & poridae (2) & & & & \\
\hline 299 & Sylvilagus andinus (Thomas, 1897) & Conejo andino, liebre andina & VOC & & Ruedas et al. 2017 \\
\hline 300 & Sylvilagus brasiliensis (Linnaeus, 1758) & Conejo brasileño, liebre amazónica & VOC, PAR, YUN, SB & & Vivar \& La Rosa 2003, Ruedas et al. 2017 \\
\hline \multicolumn{6}{|c|}{ Superorden Laurasiatheria } \\
\hline \multicolumn{6}{|c|}{ Eulipotyphla (3) } \\
\hline \multicolumn{6}{|c|}{ Soricidae (3) } \\
\hline 301 & Cryptotis evaristoi Zeballos, Pino, Medina, Pari \& Ceballos, 2018 & Musaraña de orejas cortas de Evaristo & PAR, YUN & $\mathrm{E}$ & Zeballos et al. 2018a \\
\hline 302 & Cryptotis montivagus (Anthony, 1921) & Musaraña ecuatoriana canosa & PAR, YUN & & Zeballos et al. 2018a \\
\hline 303 & Cryptotis peruviensis Vivar, Pacheco \& Valqui, 1997 & Musaraña de orejas cortas peruana & PAR, YUN & E & Vivar et al. 1997, Zeballos et al. 2018a \\
\hline & tera (187) & & & & \\
\hline & ballonuridae (14) & & & & \\
\hline 304 & Centronycteris centralis Thomas, 1912 & Murciélago peludo de Centro América & YUN, SB & & Hice \& Solari 2002 \\
\hline 305 & Centronycteris maximiliani (Fischer, 1829) & Murciélago velludo de Maximiliano & SB & & Hice et al. 2004, Medina et al. 2015 \\
\hline 306 & Cormura brevirostris (Wagner, 1843) & Murciélago de saco ventral & YUN, SB & & Medina et al. 2015, Voss et al. 2016 \\
\hline 307 & Cyttarops alecto Thomas, 1913 & Murciélago de orejas pequeñas & SB & & Velazco et al. 2011, Ludeña \& Medina 2017 \\
\hline 308 & Diclidurus albus Wied-Neuwied, 1820 & Murciélago blanco común & SB & & $\begin{array}{l}\text { Escobedo \& Velazco 2012, Fernandez-Arellano \& Torres- } \\
\text { Vásquez } 2013\end{array}$ \\
\hline 309 & Diclidurus isabella (Thomas, 1920) & Murciélago fantasma de Isabel & SB & & Escobedo \& Velazco 2012, Velazco et al. 2021a \\
\hline 310 & Peropteryx kappleri Peters, 1867 & Murciélago de sacos de kappler & YUN, SB & & Lim et al. 2010, Velazco \& Patterson 2019 \\
\hline 311 & Peropteryx leucoptera Peters, 1867 & Murciélago de sacos aliblanco & SB & & Lim et al. 2010, Díaz \& Linares-García 2012 \\
\hline 312 & Peropteryx macrotis (Wagner, 1843) & Murciélago de sacos orejudo & $\mathrm{SB}, \mathrm{SP}$ & & Voss et al. 2016, Ramos-Rodríguez et al. 2017 \\
\hline 313 & Peropteryx pallidoptera Lim, Engstrom, Reid, Simmons, Voss \& Fleck, 2010 & Murciélago de sacos de alas pálidas & SB & & Díaz 2011, Medina et al. 2015 \\
\hline 314 & Rhynchonycteris naso (Wied-Neuwied, 1820) & Murcielaguito narigudo & $S B, S P$ & & Velazco et al. 2011, Voss et al. 2016 \\
\hline 315 & Saccopteryx bilineata (Temminck, 1838) & Murcielaguito negro de listas & $\mathrm{BPP}, \mathrm{SB}, \mathrm{SP}$ & & Quintana et al. 2009, Medina et al. 2015 \\
\hline 316 & Saccopteryx canescens Thomas, 1901 & Murcielaguito de listas difusas & SB & & Tejedor 2003, Voss et al. 2016 \\
\hline 317 & Saccopteryx leptura (Schreber, 1774) & Murcielaguito pardo de listas & SB & & Escobedo 2015, Ramos-Rodríguez et al. 2017 \\
\hline & yllostomidae (106) & & & & \\
\hline
\end{tabular}




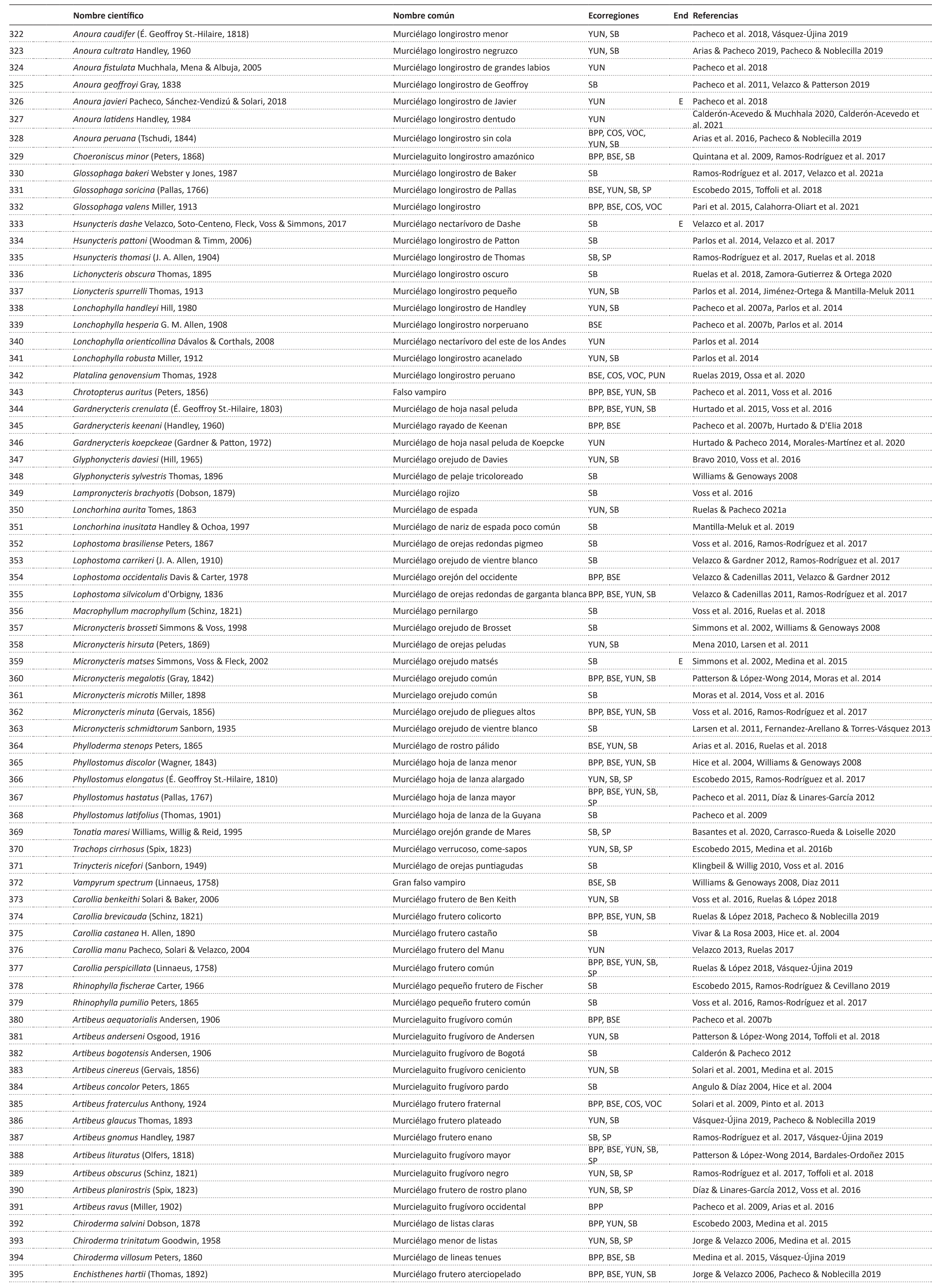




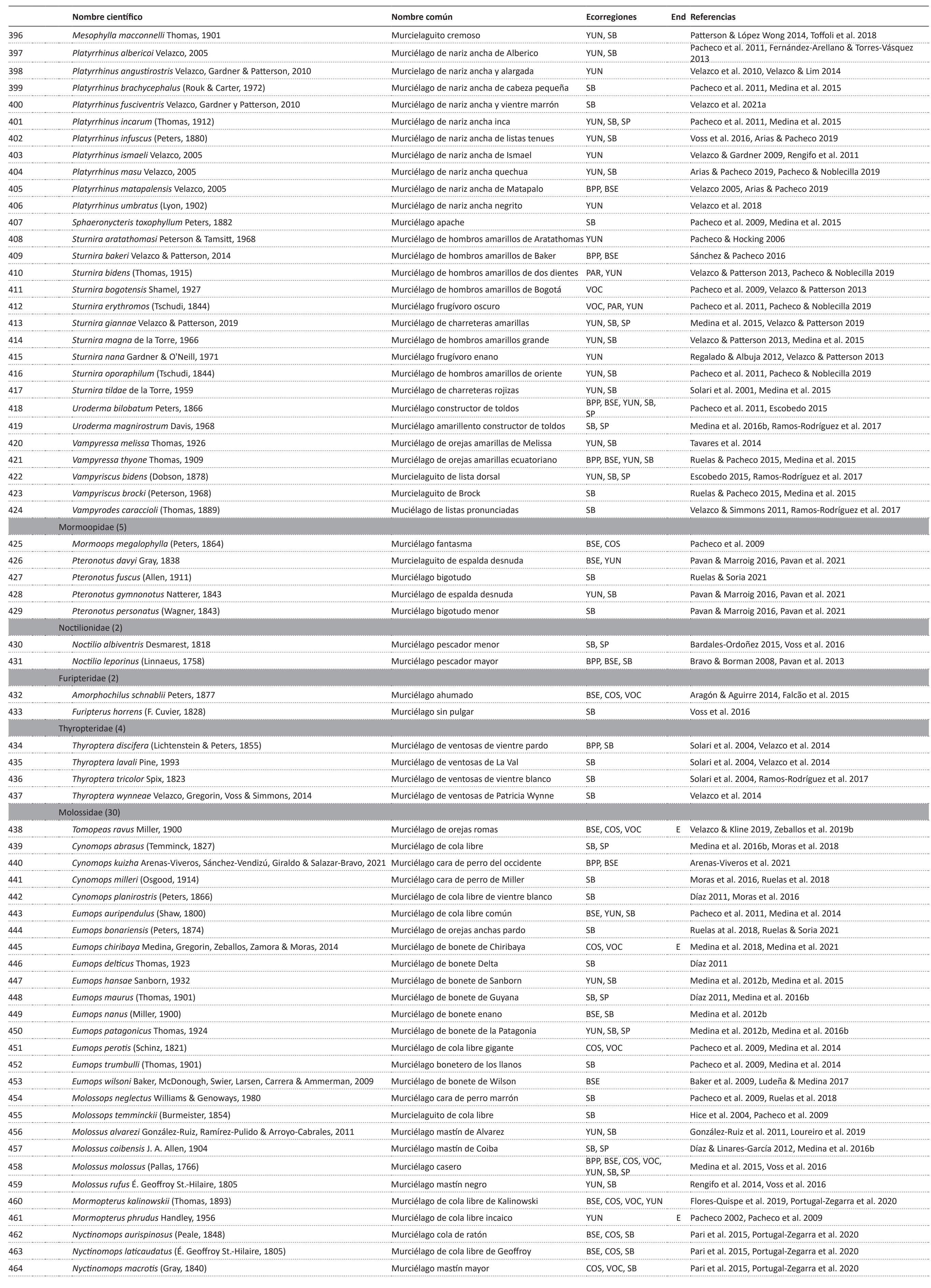




\begin{tabular}{|c|c|c|c|c|}
\hline & Nombre científico & Nombre común & Ecorregiones & Referencias \\
\hline 465 & Promops centralis Thomas, 1915 & Murciélago mastín acanelado & $\mathrm{COS}, \mathrm{SB}, \mathrm{SP}$ & Hice et al. 2004, Gregorin \& Chiquito 2010 \\
\hline 466 & Promops davisoni Thomas, 1921 & Murciélago mastín de Davison & $B S E, C O S, V O C$ & Pari et al. 2015, Flores-Quispe et al. 2015 \\
\hline \multirow[t]{2}{*}{467} & Tadarida brasiliensis (I. Geoffroy St.-Hilaire, 1824) & Murciélago de cola libre del Brasil & $\begin{array}{l}\text { BSE, COS, VOC, } \\
\text { YUN, SB }\end{array}$ & Pacheco et al. 2011, Zegarra et al. 2020 \\
\hline & spertilionidae (24) & & & \\
\hline 468 & Eptesicus andinus J. A. Allen, 1914 & Murciélago café andino & YUN & Pacheco \& Noblecilla 2019 \\
\hline 469 & Eptesicus brasiliensis (Desmarest, 1819) & Murciélago parduzco & SB, SP & Medina et al. 2015, Divoll et al. 2015 \\
\hline 470 & Eptesicus chiriquinus Thomas, 1920 & Murciélago marrón chiriquino & BPP, BSE, YUN & Pacheco et al. 2007b \\
\hline 471 & Eptesicus furinalis (d'Orbigny, 1847) & Murciélago pardo menor & $\mathrm{SB}, \mathrm{SP}$ & Quintana et al. 2009, Medina et al. 2016b \\
\hline 472 & Eptesicus innoxius (Gervais, 1841) & Murciélago café inofensivo & BPP, BSE, COS & Pacheco et al. 2007b, Loaiza et al. 2020 \\
\hline 473 & Eptesicus (Histiotus) laephotis (Thomas, 1916) & Murciélago orejudo de Thomas & $\cos$ & Aragón \& Aguirre 2014, Calizaya-Mamani 2017 \\
\hline 474 & Eptesicus (Histiotus) mochica Velazco, Cunha, Cláudio, Giménez \& Giannini, 2021 & Murciélago orejón Moche & $\cos$ & Velazco et al. 2021b \\
\hline 475 & Eptesicus (Histiotus) montanus (Philippi \& Landbeck, 1861) & Murciélago orejón andino & COS, VOC, PUN, YUN & Giménez et al. 2019, Rodríguez-Posada et al. 2021 \\
\hline 476 & Eptesicus (Histiotus) velatus (I. Geoffroy St.-Hilaire, 1824) & Murciélago orejón del Trópico & YUN & Pacheco et al. 2011, Arias et al. 2016 \\
\hline 477 & Lasiurus arequipae Málaga, Diaz, Arias \& Medina, 2020 & Murciélago acanelado de Arequipa & COS, VOC & Málaga et al. 2020 \\
\hline 478 & Lasiurus blossevillii (Lesson \& Garnot, 1826) & Murciélago rojizo & $\begin{array}{l}\text { BPP, BSE, COS, YUN, } \\
\text { SB }\end{array}$ & Mena \& Williams 2002, Mena 2010 \\
\hline 479 & Lasiurus ega (Gervais, 1856) & Murciélago amarillento & BPP, SB & Quintana et al. 2009, Málaga et al. 2020 \\
\hline 480 & Lasiurus villosissimus (É. Geoffroy St.-Hilaire, 1806) & Murciélago escarchado & PUN, YUN, SB, SP & Baird et al. 2017, Novaes et al. 2018 \\
\hline 481 & Rhogeessa hussoni Genoways \& Baker, 1996 & Murciélago amarillo pequeño del este & SP & Medina et al. 2016b \\
\hline 482 & Rhogeessa io Thomas, 1903 & Murciélago amarillo pequeño del sur & SP & Medina et al. 2016b \\
\hline 483 & Rhogeessa velilla Thomas, 1903 & Murciélago amarillo pequeño de alas negras & BPP, BSE & Pacheco et al. 2007b, Novoa et al. 2011 \\
\hline 484 & Myotis albescens (É. Geoffroy St.-Hilaire, 1806) & Murcielaguito plateado & $\begin{array}{l}\text { BPP, BSE, YUN, SB, } \\
\text { SP }\end{array}$ & Pacheco et al. 2011, Díaz \& Linares-García 2012 \\
\hline 485 & Myotis atacamensis (Lataste, 1892) & Murcielaguito de Atacama & BSE, COS, VOC & Pari et al. 2015, Moratelli et al. 2019 \\
\hline 486 & Myotis bakeri Moratelli, Novaes, Carrión Bonilla \& Wilson, 2019 & Murcielaguito de Baker & $\cos$ & Moratelli et al. 2019 \\
\hline 487 & Myotis caucensis J. A. Allen, 1914 & Murcielaguito del Cauca & SB & Moratelli et al. 2013, Moratelli et al. 2019 \\
\hline 488 & Myotis keaysi J. A. Allen, 1914 & Murciélago negruzco & $\begin{array}{l}\text { BPP, BSE, VOC, YUN, } \\
\text { SB }\end{array}$ & Patterson \& López-Wong 2014, Pacheco \& Noblecilla 2019 \\
\hline 489 & Myotis nigricans (Schinz, 1821) & Murciélago negruzco común & $\begin{array}{l}\text { BPP, BSE, COS, YUN, } \\
\text { SB, SP }\end{array}$ & Montenegro \& Moya 2011, Voss et al. 2016 \\
\hline 490 & Myotis oxyotus (Peters, 1867) & Murciélago negruzco grande & COS, VOC, YUN, SB & Pacheco \& Noblecilla 2019, Moratelli et al. 2019 \\
\hline 491 & Myotis riparius Handley, 1960 & Murcielaguito acanelado & $\begin{array}{l}\text { BPP, BSE, YUN, SB, } \\
\text { SP }\end{array}$ & Voss et al. 2016, Ramos-Rodríguez et al. 2017 \\
\hline \multirow[t]{3}{*}{492} & Myotis simus Thomas, 1901 & Murciélago vespertino aterciopelado & YUN, SB & Moratelli \& Wilson 2011, Moratelli et al. 2011 \\
\hline & ora (33) & & & \\
\hline & idae (8) & & & \\
\hline 493 & Leopardus garleppi (Matschie, 1912) & Gato de Garlepp, gato del pajonal, oscollo & COS, VOC, PUN, YUN & García-Olaechea et al. 2013, Nascimento et. al. 2021 \\
\hline 494 & Leopardus jacobita (Cornalia, 1865) & Gato montés, gato andino, gato de Jacobita & PUN & Cossíos et al. 2007, Ruiz-García et al. 2013 \\
\hline 495 & Leopardus pardalis (Linnaeus, 1758) & Ocelote, tigrillo, gato onza, matsonsori & $\begin{array}{l}\text { BPP, BSE, VOC, YUN, } \\
\text { SB }\end{array}$ & Fleck \& Harder 2000, Jiménez et al. 2010 \\
\hline 496 & Leopardus tigrinus (Schreber, 1775) & Gato tigre común, tigrino, oncilla & YUN & Rodríguez \& Amanzo 2001, Vivar \& La Rosa 2003 \\
\hline 497 & Leopardus wiedii (Schinz, 1821) & Huamburushu, margay & BPP, BSE, SB, SP & Vivar \& La Rosa 2003, Hurtado \& Pacheco 2015 \\
\hline 498 & Puma concolor (Linnaeus, 1771) & Puma, león, lluichu-puma & $\begin{array}{l}\text { BPP, BSE, COS, VOC, } \\
\text { PAR, PUN, YUN, SB }\end{array}$ & Zeballos-Patrón et al. 2001, Jiménez et al. 2010 \\
\hline 499 & Puma yagouaroundi (É. Geoffroy Saint-Hilaire, 1803) & Yahuarundi & $B P P, B S E, Y U N, S B$ & Garcia-Olaechea et al. 2019, Pacheco et al. 2020a \\
\hline \multirow[t]{2}{*}{500} & Panthera onca (Linnaeus, 1758) & Jaguar, otorongo, uturuncu & YUN, SB, SP & Fleck \& Harder 2000, Vivar \& La Rosa 2003 \\
\hline & nidae (6) & & & \\
\hline 501 & Atelocynus microtis (Sclater, 1883) & Zorro negro orejicorto, perro de monte & YUN, SB, SP & Fleck \& Harder 2000, Vivar \& La Rosa 2003 \\
\hline 502 & Chrysocyon brachyurus (Illiger, 1815) & Lobo de crín & SP & Medina et al. 2016b \\
\hline 503 & Lycalopex (Pseudalopex) culpaeus (Molina, 1782) & Zorro colorado & COS, VOC, PUN, YUN & Zeballos-Patrón et al. 2001, Vivar \& Pacheco 2014 \\
\hline 504 & Lycalopex (Pseudalopex) griseus (Gray, 1837) & Zorro gris & $\cos$, voc & Zeballos-Patrón et al. 2001, Vivar \& Pacheco 2014 \\
\hline 505 & Lycalopex (Pseudalopex) sechurae (Thomas, 1900) & Zorro de Sechura & BSE, COS, VOC & Cossíos 2010, Hurtado \& Pacheco 2015 \\
\hline \multirow[t]{2}{*}{506} & Speothos venaticus (Lund, 1842) & Perro de monte, perro de bosque & YUN, SB & Solari et al. 2006, Patterson \& López-Wong 2014 \\
\hline & sidae (1) & & & \\
\hline \multirow[t]{2}{*}{507} & Tremarctos ornatus (F. G. Cuvier, 1825) & Oso de anteojos, ucumari, ucucu & $\begin{array}{l}\text { BSE, VOC, PAR, PUN, } \\
\text { YUN }\end{array}$ & Pacheco \& Arias 2001, Vivar \& La Rosa 2003 \\
\hline & ariidae (3) & & & \\
\hline 508 & Arctocephalus australis (Zimmermann, 1783) & Lobo fino, cochapuma & $\cos$ & Zeballos-Patrón et al. 2001 \\
\hline 509 & Arctocephalus philippii (Peters, 1866) & Lobo fino de Juan Fernández & $\cos$ & Pacheco et al. 2020a \\
\hline \multirow[t]{2}{*}{510} & Otaria flavescens (Shaw, 1800) & Lobo chusco, cochapuma & $\cos$ & Zeballos-Patrón et al. 2001 \\
\hline & Istelidae (8) & & & \\
\hline 511 & Lontra felina (Molina, 1782) & Gato marino, chingungo, huallaque & $\cos$ & Zeballos-Patrón et al. 2001, Hurtado et al. 2016b \\
\hline 512 & Lontra longicaudis (Olfers, 1818) & Lobo pequeño de río, nutria, mayopuma & BSE, VOC, YUN, SB & Vivar \& La Rosa 2003, Pacheco et al. 2007a \\
\hline 513 & Pteronura brasiliensis (Gmelin, 1788) & Lobo grande de río, nutria grande & $\mathrm{SB}, \mathrm{SP}$ & Merino et al. 2009, Medina et al. 2016b \\
\hline 514 & Eira barbara (Linnaeus, 1758) & Tejón, manco, omeiro, huamingo & $\begin{array}{l}\text { BPP, BSE, YUN, SB, } \\
\text { SP }\end{array}$ & Vivar \& La Rosa 2003, Gonzales \& Llerena 2014 \\
\hline 515 & Galictis cuja (Molina, 1782) & Hurón menor, cuya & COS, VOC, PUN & Bornholdt et al. 2013 \\
\hline 516 & Galictis vittata (Schreber, 1776) & Hurón grande, grisón & SB & Vivar \& La Rosa 2003, Bornholdt et al. 2013 \\
\hline 517 & Neogale africana (Desmarest, 1818) & Comadreja rayada, comadreja amazónica & SB & Voss \& Fleck 2017, Patterson et al. 2021 \\
\hline \multirow[t]{2}{*}{518} & Neogale frenata (Lichtenstein, 1831) & Comadreja, tolompeo, achocalla & $\begin{array}{l}\text { VOC, PAR, PUN, } \\
\text { YUN, SB }\end{array}$ & Ramírez-Chaves et al. 2012, Patterson et al. 2021 \\
\hline & phitidae (2) & & & \\
\hline 519 & Conepatus chinga (Molina, 1782) & Zorrino, añas & $\begin{array}{l}\text { COS, VOC, PUN, } \\
\text { YUN, SB }\end{array}$ & Medina et al. 2009, Medina et al. 2012a \\
\hline \multirow[t]{2}{*}{520} & Conepatus semistriatus (Boddaert, 1785) & Zorrino hocico de cerdo & $\begin{array}{l}\text { BSE, COS, VOC, PAR, } \\
\text { PUN, YUN }\end{array}$ & Dragoo et al. 2003, Amanzo 2003 \\
\hline & cyonidae (5) & & & \\
\hline 521 & Bassaricyon alleni Thomas, 1880 & Olingo, chosna pericote & YUN, SB & Vivar \& La Rosa 2003, Helgen et al. 2013 \\
\hline 522 & Nasua nasua (Linnaeus, 1766) & Coatí de cola anillada, mishasho & $\begin{array}{l}\text { BPP, BSE, YUN, SB, } \\
\text { SP }\end{array}$ & Torres-Oyarce et al. 2017, Shanee \& Shanee 2018 \\
\hline 523 & Nasua olivacea (Gray, 1865) & Coatí andino, capiso & YUN & Pacheco et al. 2009, Mena \& Yagui 2019 \\
\hline 524 & Potos flavus (Schreber, 1774) & Chosna & $\begin{array}{l}\text { BPP, BSE, YUN, SB, } \\
\text { SP }\end{array}$ & Hurtado et al. 2016b, Sánchez \& Vásquez 2007 \\
\hline
\end{tabular}


PACHeco et AL.

\begin{tabular}{|c|c|c|c|c|}
\hline & Nombre científico & Nombre común & Ecorregiones & End Referencias \\
\hline \multirow[t]{3}{*}{525} & Procyon cancrivorus (G. [Baron] Cuvier, 1798) & Osito cangrejero, osito lavador & $B P P, B S E, S B$ & Fleck \& Harder 2000 \\
\hline & \multicolumn{4}{|c|}{ Perissodactyla (2) } \\
\hline & \multicolumn{4}{|c|}{ Tapiridae (2) } \\
\hline 526 & Tapirus pinchaque (Roulin, 1829) & Tapir de montaña, pinchaque & PAR, YUN & Jiménez et al. 2010, Mena \& Hiyo-Bellido 2016 \\
\hline \multirow[t]{3}{*}{527} & Tapirus terrestris (Linnaeus, 1758) & Tapir del Ilano amazónico, sachavaca & YUN, SB, SP & Medina et al. 2016b, Torres-Oyarce et al. 2017 \\
\hline & \multicolumn{4}{|c|}{ Artiodactyla (46) } \\
\hline & \multicolumn{4}{|c|}{ Tayassuidae (2) } \\
\hline 528 & Dicotyles tajacu (Linnaeus, 1758) & Sajino, pecarí de collar & $\begin{array}{l}\text { BPP, BSE, YUN, SB, } \\
\text { SP }\end{array}$ & Perez-Peña et al. 2017, Acosta et al. 2020 \\
\hline \multirow[t]{2}{*}{529} & Tayassu pecari (Link, 1795) & Pecarí boquiblanco, huangana & YUN, SB, SP & Mena \& Hiyo-Bellido 2016, Perez-Peña et al. 2017 \\
\hline & \multicolumn{4}{|c|}{ Camelidae (4) } \\
\hline 530 & Lama glama (Linnaeus, 1758) & Llama & PUN & Cristofanelli et al. 2004 \\
\hline 531 & Lama guanicoe (Müller, 1776) & Guanaco & COS, VOC, PUN & Castillo et al. 2008, Marín et al. 2008 \\
\hline 532 & Vicugna pacos (Linnaeus, 1758) & Alpaca & PUN & Bryant \& Farfan 1984, López-Urbina et al. 2009 \\
\hline \multirow[t]{2}{*}{533} & Vicugna vicugna (Molina, 1782) & Vicuña & PUN & Marín et al. 2007 \\
\hline & \multicolumn{4}{|c|}{ Cervidae (8) } \\
\hline 534 & Blastocerus dichotomus (Illiger, 1815) & Ciervo de los pantanos & SB, SP & Pacheco \& Vivar 1996, Medina et al. 2016b \\
\hline 535 & Hippocamelus antisensis (d'Orbigny, 1834) & Ciervo altoandino, taruca & PUN & Barrio 2006 \\
\hline 536 & Mazama americana (Erxleben, 1777) & Venado colorado, puca luicho & $\begin{array}{l}\text { BPP, BSE, VOC, YUN, } \\
\text { SB, SP }\end{array}$ & Vivar \& La Rosa 2003, Gutiérrez et al. 2017 \\
\hline 537 & Mazama chunyi Hershkovitz, 1959 & Venado enano & YUN & Rumiz et al. 2007, Rumiz \& Pardo 2010 \\
\hline 538 & Mazama nemorivaga (F. Cuvier, 1817) & Venado gris, uchpa luicho & $S B, S P$ & Rossi et al. 2010a, Aquino et al. 2012 \\
\hline 539 & Mazama rufina (Pucheran, 1851) & Venado colorado enano & YUN & Barrio 2010 \\
\hline 540 & Odocoileus peruvianus (Gray, 1874) & Venado de cola blanca, venado gris & $\begin{array}{l}\text { BSE, COS, VOC, PAR, } \\
\text { PUN, YUN, SB }\end{array}$ & Barrio 2006, Baca-Rosado 2017 \\
\hline \multirow[t]{2}{*}{541} & Pudu mephistophiles (de Winton, 1896) & Pudu, sachacabra & YUN & Escamilo et al. 2010, Shanee \& Shanee 2018 \\
\hline & \multicolumn{4}{|c|}{ Balaenidae (1) } \\
\hline 542 & Eubalaena australis (Desmoulins, 1822) & Ballena franca del sur & OCE & Reyes 2009 \\
\hline \multicolumn{5}{|c|}{ Balaenopteridae (6) } \\
\hline 543 & Balaenoptera bonaerensis Burmeister, 1867 & Ballena minke austral & OCE & Reyes 2009 \\
\hline 544 & Balaenoptera borealis Lesson, 1828 & Ballena de Sei & OCE & Jefferson et al. 1993 \\
\hline 545 & Balaenoptera edeni Anderson, 1879 & Ballena de Bryde & OCE & Reyes 2009 \\
\hline 546 & Balaenoptera musculus (Linnaeus, 1758) & Rorcual gigante, ballena azul & OCE & Jefferson et al. 1993 \\
\hline 547 & Balaenoptera physalus (Linnaeus, 1758) & Rorcual común, ballena de aleta & OCE & Jefferson et al. 1993 \\
\hline 548 & Megaptera novaeangliae (Borowski, 1781) & Ballena jorobada, yubarta & OCE & Reyes 2009 \\
\hline \multicolumn{5}{|c|}{ Delphinidae (17) } \\
\hline 549 & Delphinus capensis Gray, 1828 & Delfín común de hocico largo & OCE & Reyes 2009 \\
\hline 550 & Delphinus delphis Linnaeus, 1758 & Delfín común de hocico corto & OCE & Jefferson et al. 1993 \\
\hline 551 & Feresa attenuata Gray, 1874 & Orca enana & OCE & Jefferson et al. 1993 \\
\hline 552 & Globicephala macrorhynchus Gray, 1846 & Delfín piloto de aleta corta & OCE & Reyes 2009 \\
\hline 553 & Globicephala melas (Traill, 1809) & Delfín piloto de aleta larga & OCE & Jefferson et al. 1993 \\
\hline 554 & Grampus griseus (G. Cuvier, 1812) & Delfín gris, delfín de Risso & OCE & Reyes 2009 \\
\hline 555 & Lagenorhynchus obscurus (Gray, 1828) & Delfín obscuro & OCE & Reyes 2009 \\
\hline 556 & Lissodelphis peronii (Lacépède, 1804) & Delfín de perón, delfín liso austral & OCE & Reyes 2009 \\
\hline 557 & Orcinus orca (Linnaeus, 1758) & Orca verdadera, tonina & OCE & Jefferson et al. 1993 \\
\hline 558 & Peponocephala electra (Gray, 1846) & Delfín cabeza de melón & OCE & Reyes 2009 \\
\hline 559 & Pseudorca crassidens (Owen, 1846) & Falsa orca común, orca falsa & OCE & Jefferson et al. 1993 \\
\hline 560 & Sotalia fluviatilis (Gervais \& Deville, 1853) & Bufeo gris, bufeo negro & SB & Fleck \& Harder 2000, Quintana et al. 2009 \\
\hline 561 & Stenella attenuata (Gray, 1846) & Delfín con brida, delfín manchado pantropical & OCE & Reyes 2009 \\
\hline 562 & Stenella coeruleoalba (Meyen, 1833) & Delfín rayado, delfín listado & OCE & Jefferson et al. 1993 \\
\hline 563 & Stenella longirostris (Gray, 1828) & Delfín hilandero, delfín tornillo & OCE & Reyes 2009 \\
\hline 564 & Steno bredanensis (G. Cuvier en Lesson, 1828) & Delfín de dientes rugosos & OCE & Reyes 2009 \\
\hline 565 & Tursiops truncatus (Montagu, 1821) & Delfín pico de botella & OCE & Jefferson et al. 1993 \\
\hline \multicolumn{5}{|c|}{ Phocoenidae (1) } \\
\hline 566 & Phocoena spinipinnis Burmeister, 1865 & Marsopa espinosa, chancho marino & OCE & Jefferson et al. 1993 \\
\hline & yyseteridae (3) & & & \\
\hline 567 & Kogia breviceps (de Blainville, 1838) & Cachalote de cabeza pequeña & OCE & Reyes 2009 \\
\hline 568 & Kogia sima (Owen, 1866) & Cachalote enano & OCE & Reyes 2009 \\
\hline 569 & Physeter macrocephalus Linnaeus, 1758 & Cachalote & OCE & Reyes 2009 \\
\hline & iidae (1) & & & \\
\hline 570 & Inia geoffrensis (Blainville, 1817) & Bufeo colorado, delfín rosado & SB & Fleck \& Harder 2000, Quintana et al. 2009 \\
\hline & phiidae (3) & & & \\
\hline 571 & Mesoplodon grayi von Haast, 1876 & Ballena de pico de Gray & OCE & Reyes 2009 \\
\hline 572 & Mesoplodon peruvianus Reyes, Mead \& van Waerebeek, 1991 & Ballena de pico peruana & OCE & Reyes 2009 \\
\hline 573 & Ziphius cavirostris G. Cuvier, 1823 & Ballena de pico de Cuvier & OCE & Reyes 2009 \\
\hline & Total especies (573) & & & 87 \\
\hline
\end{tabular}

